Cíntia Guilhardi

\title{
Independência Funcional entre Tatos e Mandos: Análise de Respostas Verbais Baseadas na Seleção de Estímulos
}

\author{
Tese aprensentada ao Instituto de \\ Psicologia da Universidade de São Paulo, \\ para obtenção do título de DOUTORA em \\ Psicologia \\ Área de Concentração: Psicologia \\ Experimental \\ Orientação: Profa. Dra. Maria Martha \\ Hübner
}

São Paulo

Janeiro de 2009 
AUTORIZO A REPRODUÇÃO E DIVULGAÇÃO TOTAL OU PARCIAL DESTE TRABALHO, POR QUALQUER MEIO CONVENCIONAL OU ELETRÔNICO, PARA FINS DE ESTUDO E PESQUISA, DESDE QUE CITADA A FONTE.

Catalogação na publicação

Serviço de Biblioteca e Documentação

Instituto de Psicologia da Universidade de São Paulo

Guilhardi, Cíntia.

Independência funcional entre tatos e mandos: análise de respostas verbais baseadas na seleção de estímulos / Cíntia Guilhardi; orientadora Maria Matha Costa Hübner. -- São Paulo, 2009.

$106 \mathrm{p}$.

Tese (Doutorado - Programa de Pós-Graduação em Psicologia. Área de Concentração: Psicologia Experimental) - Instituto de Psicologia da Universidade de São Paulo.

1. Análise do comportamento 2. Comunicação verbal 3. Análise funcional I. Título. 
Cíntia Guilhardi

\title{
Independência Funcional entre Tatos e Mandos: Análise de Respostas Verbais Baseadas na Seleção de Estímulos
}

\author{
Tese aprensentada ao Instituto de \\ Psicologia da Universidade de São Paulo, \\ para obtenção do título de DOUTORA em \\ Psicologia \\ Área de Concentração: Psicologia \\ Experimental \\ Orientação: Profa. Dra. Maria Martha \\ Hübner
}

Aprovado em:

Banca Examinadora:

Profa. Dra.

Instituição:

Assinatura:

Profa. Dra.

Instituição:

Assinatura:

Profa. Dra.

Instituição:

Assinatura:

Profa. Dra.

Instituição:

Assinatura:

Profa. Dra.

Instituição:

Assinatura: 
Aos participantes dessa tese, com amor e gratidão, por tudo o que com vocês aprendi 


\section{AGRADECIMENTOS}

À minha orientadora por ter me dado a honra de ser aluna da sua primeira turma de doutores, por me apoiar na elaboração do meu problema de pesquisa e por ter se dedicado a este trabalho a longo desses cinco anos...

Aos meus professores de Graduação e Mestrado que nunca mediram esforços para aprefeiçoar minha formação, sempre com muito amor e competência. Sou eternamente grata a vocês: Ziza, Téia, Nilza, Paula Gióia e um agradecimento especial à Maria Amália que sempre se mostrou disponível em todos os momentos...

Ao meu pai, o Big Bang da minha vida...

À Leila e a KK que com todo respeito e companheirismo estiveram ao meu lado ao longo desses anos. Não há palavras para agradecer a cumplicidade, amizade e profissionalismo dessas duas meninas que são tão importantes na minha vida.

À equipe da Gradual que participou diretamente e indiretamente desse trabalho, seja marcando reuniões, coletando e discutindo dados, ajudando na lida com os participantes, dando toda a força e apoio necessários para a elaboração dessa tese. Meu agradecimento especial à Ju Godoi, Téia, Lú Romano, Cris e Adriana.

Não poderia deixar de agradecer ao meu marido, Guilherme, pelo companheirismo nas alegrias e tristezas e por acreditar na importância desse trabalho na minha vida e na vida daqueles que poderão usufruir deste conhecimento...

Aos pais dos participantes que apesar da dura realidade lutam em benefício do desenvolvimento de seus filhos. Obrigada pela disponibilidade e carinho... 
GUILHARDI, C. Independência Funcional entre Tatos e Mandos: Análise de Respostas Verbais Baseadas na Seleção de Estímulos. 2009. 106 f. Tese (Doutorado) - Instituto de Psicologia, Universidade de São Paulo, São Paulo, 2009

Este projeto teve como objetivo (a) investigar a independência funcional entre os operantes tato e mando com respostas verbais baseadas na seleção de estímulos e (b) investigar algumas variáveis que pudessem facilitar que uma dada topografia verbal ensinada em tato fosse emitida em mando sem treino direto e vice-versa. Quatro crianças com diagnóstico de autismo e uma criança com atraso de linguagem foram participantes do estudo. Primeiramente, no Estudo 1, T1 foi ensinado a emitir tatos puros de cinco objetos necessários para a execução de uma cadeia comportamental. Testou-se, então, a emissão das mesmas topografias de respostas na condição de mando. Em um segundo momento, no Estudo 2, T2 foi ensinado a emitir duas topografias de tato impuros (além do participante ser elogiado após a emissão do tato durante o treino, o mesmo recebia um brinquedo, que cumpria a função de um reforço condicionado) e testado em mando, enquanto M1 e M2 foram ensinados a emitir duas topografias de mando impuro (além de adquirirem o item específico após a emissão da resposta verbal, os participantes eram elogiados pelo experimentador) e testados na condição de tato. Em um terceiro momento, no Estudo 3, M3 foi ensinado a emitir mandos para quatro objetos necessários para completar quatro cadeias comportamentais. Concomitante a emissão das respostas verbais de seleção de estímulos emitidas pelo participante, o experimentador nomeava (resposta vocal) o item que era pedido. Os resultados apontaram independência funcional entre os operantes tato e mando com respostas verbais baseadas na seleção de estímulos. O treino de topografias verbais na condição de tato impuro pareceu facilitar que as mesmas topografias fossem emitidas na condição de mando, sem treino direto e vice-versa. Por fim, a resposta verbal vocal emitida pelo experimentador facilitou que as topografias verbais ensinadas em mando fossem emitidas por M3 em tato e também pareceu ser importante na emissão de respostas verbais vocais.

Palavras-chave: Análise do Comportamento, Comunicação Verbal, Análise Funcional. 
GUILHARDI, C. Functional Independence between Tacts and Mands: Analysis of Selection-Based Verbal Responses. 2009. $106 \mathrm{f}$. Thesis (Doctoral) - Institute of Psychology, University of São Paulo, São Paulo, 2009.

This project aimed to (a) investigate functional independence between mand and tact selection-based verbal behaviors and (b) investigate variables that could facilitate that a given verbal topography taught in tact could be emitted in mand and vice versa. Four children diagnosed with autism and a child with language delay were participants of the study. To begin with, in Study 1, T1 was taught to emit pure tacts of five objects necessary for the implementation of a behavioral chain. Then he was tested in same topographies of responses in mand condition. Secondly, in Study 2, T2 was taught to emit two topographies of impure tacts (in addition to the participant being praised after tacting during training, he received a toy, which fulfilled the function of conditioned reinforcer) and tested in mand, while M1 and M2 were taught to emit two topographies of impure mand (besides acquiring the specific item after the emission of verbal response, the participants were praised by the experimenter) and tested in tact. Thirdly, in Study 3, M3 was taught to mand for four objects required to complete four behavioral chains. Concomitant with the selection-based verbal behavior emitted by the participant, the experimenter named (voice response) the required item. The results showed functional independence between mand and tact for selection-based verbal behavior. The training of verbal topographies in impure tact condition seemed to facilitated the same topographies to be emitted in mand condition, without direct training and vice versa. Finally, the vocal verbal response emitted by the experimenter appeared to facilitated to topographies taught in mand to be emitted by M3 in tact and also seemed to be important in the emission of vocal verbal responses.

Keywords: Behavior Analysis, Verbal Communication, Functional Analysis. 


\section{LISTA DE TABELAS}

Tabela 1 - Seqüencias dos Treinos e Testes do Estudo de Lamarre e Holland (1985)

Tabela 2- Eventos Antecedentes e Conseqüentes às Respostas Treinadas nas Condições de Tato e Mando (Lamarre \& Holland, 1985)

Tabela 3- Seqüencias dos Testes e Treinos do Estudo de Twyman (1996).....

Tabela 4- Eventos Antecedentes e Conseqüentes às Respostas de Tato e Mando no estudo de Twyman, 1996).

Tabela 5- Cadeias Comportamentais Desenvolvidas no Experimento de Hall e Sundberg (1987)

Tabela 6- Estímulos Envolvidos na Contingência de Treino de Tato do Pré-Treino, no Experimento de Hall e Sundberg (1987)...........

Tabela 7- Seqüencias Intra Participantes e Entre Participantes dos Treinos e Testes de Mando no Experimento de Hall e Sundberg (1987)

Tabela 8- Estímulos Envolvidos na Contingência de Treino de Mando com Dica de Tato e Dica Imitativa, no Experimento de Hall e Sundberg (1987)

Tabela 9- Seqüencia e Objetivos das Etapas Experimentais do Estudo de Ziomek e Rehfeldt (2008)

Tabela Estímulos Envolvidos nas Tentativas de Treino de Mando, na $10-$ Pesquisa Conduzida por Ziomek e Rehfeldt (2008)

Tabela 11- Operantes Múltiplos Envolvidos nos Treinos de Mando e Tato nas Pesquisas de Lamarre e Holland (1985), Hall e Sundberg (1987), Twyman (1996) e Ziomek e Rehfeldt (2008)..

Tabela 12- Currículo Comportamental dos Participantes da Pesquisa na Ocasião da Coleta dos Dados

Delineamento Experimental Geral

Tabela 13 -

Definição das Classes de Respostas Verbais

Descrição do Repertório Comportamental de T1 Itens Preferidos pelo Participante T1 no Teste de Preferência de Estímulos (De Leon \& Iwata, 1996) e Cadeias Comportamentais Desenvolvidas e Ensinadas para $\mathrm{T} 1$.

Tabela 17- Seqüência dos Treinos e Testes para o Participante T1...........

Tabela 18 - Repertório Comportamental do Participante T2, na ocasião da coleta dos dados.

Tabela 19- Repertório Comportamental do Participante M1, na ocasião da coleta dos dados 
Tabela 20- Repertório Comportamental do Participante M2, na ocasião da coleta dos dados

Tabela 21- Itens Preferidos pelos Participantes T2, M1 e M2 no Teste de Preferência de Estímulos (De Leon \& Iwata, 1996) e Cadeias Comportamentais (Hall \& Sundberg, 1987) desenvolvidas e ensinadas para T2, M1 e M2

Tabela 22- Seqüência dos Treinos e Testes para os Participantes T2, M1 e M2.....

Tabela 23- Número de vezes que cada uma das Cadeias Comportamentais foi treinada com os Participantes T2, M1 e M2.

Tabela 24- Descrição do Repertório Comportamental de M3, na ocasião da coleta dos dados

Tabela 25- Itens Preferidos pelo Participante M3 no Teste de Preferência de Estímulos (De Leon \& Iwata, 1996) e Cadeias Comportamentais (Hall \& Sundberg, 1987) desenvolvidas e ensinadas para M3 ...................................................

Tabela 26- Seqüência dos Treinos e Testes para o Participante M3...........

Tabela 27- Esquema dos Operantes Tato (na condição de Teste) e Mando (na condição de Treino)

Tabela 28- Estímulos Antecedentes às Respostas Verbais Baseadas na Seleção e às Respostas Verbais Baseadas na Topografia, em Tato e em Mando.

Tabela 29- Topografias das Respostas Verbais Baseadas na Seleção de Estímulos e das Respostas Verbais Baseadas na Topografia e seus respectivos Eventos Conseqüentes, nas Condições de Tato e Mando 


\section{LISTA DE FIGURAS}

Figura 1- Ilustração da disponibilização dos materiais à mesa, no início de uma tentativa de Treino/Teste de Mando.............

Figura 2- Ilustração da disponibilização dos materiais à mesa, no início de uma tentativa de Treino/Teste de Tato................

Figura 3- Escores obtidos por T1 na Avaliação de Linguagem de Sundberg e Partington (1998).....................................

Figura 4- Desempenho do participante T1 no Treino de Tato dos itens caminhão, pilha, bola, quebra-cabeça e giz.....

Figura 5- Desempenho do participante T1 no Pré-Teste e Pós-Teste de Tato e Mando dos itens caminhão, pilba, bola, quebracabeça, controle-remoto, giz, bola de sabão e quebra-cabeça de números.............................................................

Figura 6- Escores obtidos pelos participantes T2, M1 e M2 na Avaliação de Linguagem proposta por Sundberg e Partington (1998)..................................................

Figura 7- Esquema dos Operantes Tato e Mando com seus respectivos Antecedentes e Conseqüentes, no Estudo 2..... Desempenho dos participantes T2, M1 e M2 no treino dos operantes tato (T2) e mando (M1 e M2)

Figura 9- Desempenho dos participantes T2, M1 e M2 no Pré-Teste e Pós-Teste para cada par de itens testado

Figura 10- Escores obtidos pelo participante M3 na Avaliação de Linguagem proposta por Sundberg e Partington (1998), na ocasião da coleta dos dados...

Figura 11- Desempenho do participante M3 nos Treinos de Mando para os itens gelo, espada, quebra-cabeça e DVD.

Figura 12- Número de respostas (baseadas na seleção de estímulos e vocais) emitidas por M3 nos testes, para os itens gelo, espada, quebra-cabeça e DVD.......................................... 
INTRODUÇÃ O........................................................... 01

MÉTODO GERAL ........................................................ 41

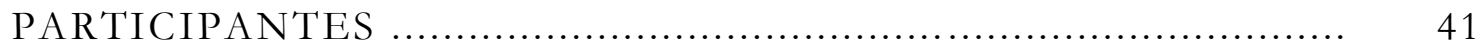

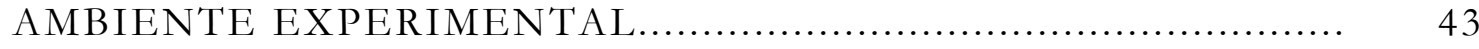

SESSÕES EXPERIMENTAIS ......................................... 44

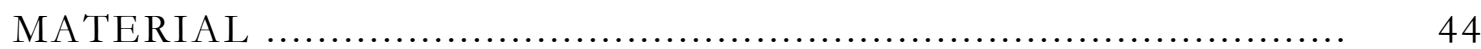

PROCEDIMENTO GERAL ........................................... 45

DELINEAMENTO EXPERIMENTAL ............................. 46

VARIÁVEIS EXPERIMENTAIS E VARIÁVEIS DE OBSERVAÇÃO.

PROCEDIMENTOS PRÉVIOS AO TREINO DOS OPERANTES VERBAIS E TREINO DE PRÉ-REQUISITOS - TESTE DE PREFERÊNCIA DE ESTÍMULOS (DE LEON \& IWATA, 1996) E TREINO DE CADEIAS COMPORTAMENTAIS (HALL \& SUNDBERG, 1897)

1. TESTE DE PREFERÊNCIA DE ESTÍMULOS (DE LEON E IWATA, 1996).

2. TREINO DE CADEIAS COMPORTAMENTAIS (HALL \& SUNDBERG, 1987)

TREINOS E TESTES DE MANDO E TATO

1. ESPECIFICIDADES DOS TREINOS E TESTES DE TATO E MANDO

1.A. TREINO E TESTES DE MANDO PROCEDIMENTO DE INTERRUPÇÃO DE CADEIA (HALL \& SUNDBERG, 1987)

1.B. TREINOS E TESTES DE TATO PROCEDIMENTO DE ESCOLHA DE ACORDO COM O MODELO...

2. PROCEDIMENTOS COMUNS NOS TREINOS E TESTES DE TATO E MANDO.

VALIDAÇÃO POR CONSENSO DAS RESPOSTAS EMITIDAS PELOS PARTICIPANTES E DO PROCEDIMENTO. 
MÉTODO 59

PARTICIPANTE 59

PROCEDIMENTOS PRÉVIOS AO TREINO DOS OPERANTES VERBAIS E TREINO DE PRÉ-REQUISITOS - TESTE DE PREFERÊNCIA DE ESTÍMULOS (DE LEON \& IWATA, 1996) E TREINO DE CADEIAS COMPORTAMENTAIS (HALL \& SUNDBERG, 1897) ..................................................... 60

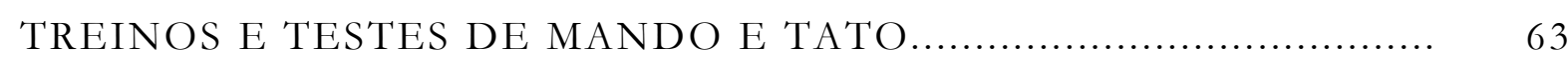

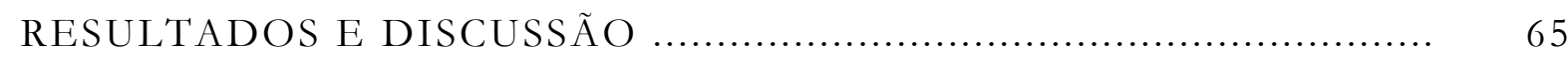

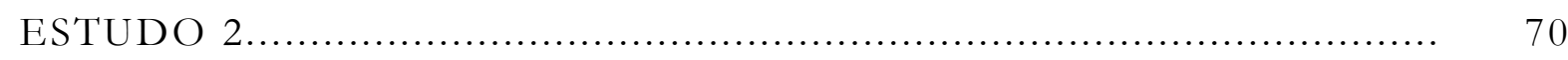

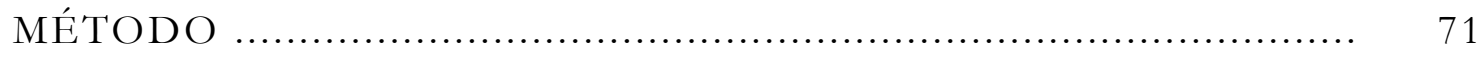

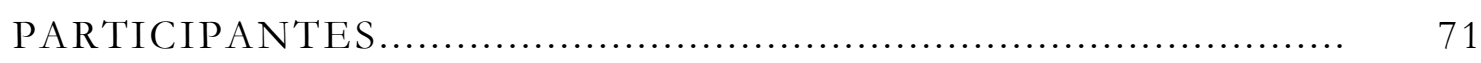

PROCEDIMENTOS PRÉVIOS AO TREINO DOS OPERANTES VERBAIS E TREINO DE PRÉ-REQUISITOS - TESTE DE PREFERÊNCIA DE ESTÍMULOS (DE LEON \& IWATA, 1996) E TREINO DE CADEIAS COMPORTAMENTAIS (HALL \&

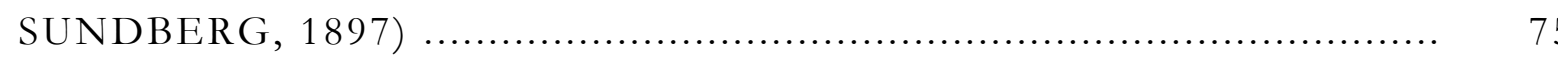

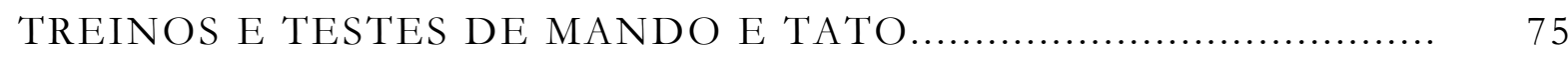

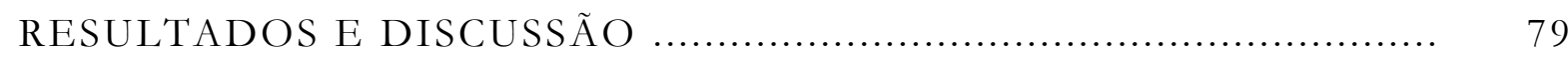

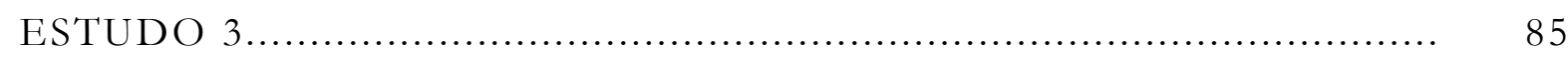

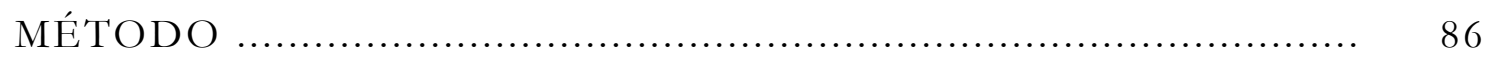

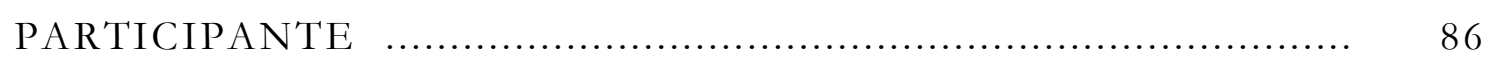

PROCEDIMENTOS PRÉVIOS AO TREINO DOS OPERANTES VERBAIS E TREINO DE PRÉ-REQUISITOS - TESTE DE PREFERÊNCIA DE ESTÍMULOS (DE LEON \& IWATA, 1996) E TREINO DE CADEIAS COMPORTAMENTAIS (HALL \& SUNDBERG, 1897) ...................................................... 88

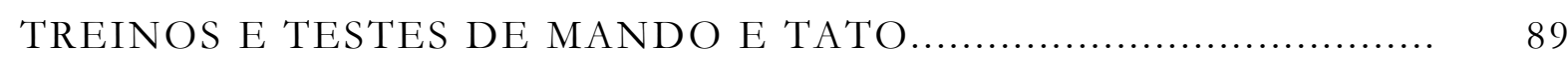

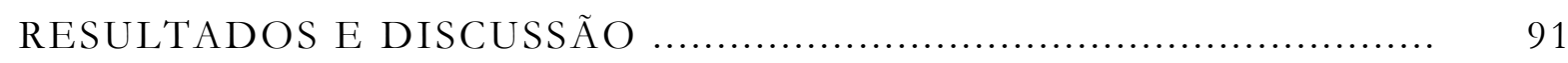

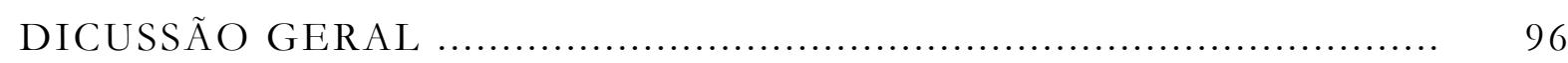

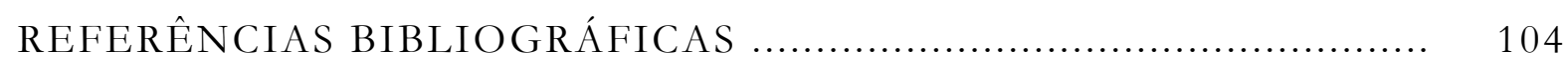


B. F. Skinner, em 1957, publicou o livro Verbal Behavior, propondo uma análise inovadora acerca do fenômeno que tradicionalmente é denominado de linguagem.

Segundo o autor, o comportamento verbal ${ }^{1}$ deve analisado como qualquer outro comportamento operante, sendo assim, também controlado por eventos antecedentes e conseqüentes às respostas (análise funcional do comportamento). No entanto, diferentemente dos demais comportamentos operantes, as conseqüências produzidas pela resposta verbal são mediadas por um ouvinte, especialmente treinado para tanto pela comunidade verbal.

Skinner (1957/1992) classificou as relações funcionais do comportamento verbal, de acordo com as diferentes relações de controle que as respostas verbais estabelecem com os estímulos antecedentes e/ou com os estímulos conseqüentes, ou seja, o autor classificou classes verbais de acordo com sua função. A cada uma dessas classes verbais Skinner denominou operante verbal ${ }^{2}$.

A seguir, são apresentadas as variáveis controladoras de dois operantes verbais definidos por Skinner (1957/1992) como mando e tato, aqui destacados por trazerem implicações conceituais e aplicadas importantes, especialmente para este estudo.

Skinner (1957/1992) definiu o mando como um operante verbal no qual uma determinada forma de resposta é controlada por condições antecedentes de privação ou estimulação aversiva e é reforçada por uma conseqüência específica. Em uma análise posterior, Michael (1993) complementou a definição de mando como um operante verbal controlado por uma operação estabelecedora (eventos,

\footnotetext{
1 A análise funcional da linguagem, conforme proposta pelo autor, contrapôs ao modelo tradicional que analisava a linguagem a partir de sua estrutura e seu significado. Justamente por isso, Skinner cunhou o termo comportamento verbal para distinguir seu objeto de estudo da "linguagem", estudada pelos lingüistas (que atribuem "às idéias", "ao significado" ou "às imagens" as "causas" do comportamento verbal).

2 Mando, tato, ecóico, intraverbal, comportamento textual, cópia e ditado são os nomes atribuídos a cada um dos principais operantes verbais.
} 
alterações, operações ambientais ou dadas condições de estímulos) que afeta o organismo por alterar momentaneamente: (a) o valor reforçador da conseqüência e (b) a força de respostas anteriormente reforçadas.

Michael (1993) fez, ainda, uma distinção entre dois tipos de operações estabelecedoras: operação estabelecedora incondicionada e operação estabelecedora condicionada. Na primeira, os eventos ou operações ambientais que alteram o valor reforçador ou a força de uma resposta são inatos. Por exemplo, a privação de água é uma operação estabelecedora inata, que, necessariamente, aumentará o valor reforçador da água e fortalecerá todas as respostas que produziram água no passado. No segundo, os eventos ambientais que alteram o valor reforçador de estímulos foram adquiridos (ou aprendidos) na história individual de cada organismo.

O tato foi definido como um operante verbal controlado por um estímulo antecedente não verbal, como um objeto ou evento ou por uma propriedade de um objeto ou evento. Ao contrário do mando, o tato não é reforçado por uma conseqüência específica, mas sim por um reforço generalizado ${ }^{3}$. Um exemplo de tato é uma criança verbalizar flor na presença de uma flor (estímulo discriminativo) e ter como conseqüência um elogio social (muito bem, por exemplo).

Embora os operante verbais tato e o mando (e outros operantes verbais) sejam diferentes entre si, uma mesma topografia de resposta pode tanto participar de um tato quanto de um mando. Por exemplo, quando uma criança verbaliza, diante de operações estabelecedoras específicas, bala e é conseqüenciada pela aquisição da mesma, podemos dizer que um mando foi emitido. A mesma criança pode verbalizar bala, na presença do objeto concreto bala e receber uma aprovação social, constituindo um tato. Neste exemplo,

\footnotetext{
${ }^{3}$ Reforçadores generalizados foram definidos por Skinner (1953) como sendo um reforçador condicionado que foi pareado com diversos reforçadores primários.
} 
pode-se dizer que a palavra bala tem duas funções distintas: uma de mando e outra de tato.

A análise do comportamento verbal, conforme proposta por Skinner (1957/1992), aponta que o uso do alfabeto fonético não estabelece nenhum compromisso acerca do significado funcional das respostas verbais, mas são as contingências de reforço estabelecidas entre falante e ouvinte que explicitam a função (significado) de cada resposta verbal. A seguinte citação de Skinner (1957/1992) explicita essa questão:

$\mathrm{Na}$ terminologia do significado, dizemos que a palavra boneca é usada, num momento, para "pedir uma boneca" e em outro "para descrever ou nos referirmos a uma boneca". Todavia, quando a resposta Boneca! foi adquirida como um mando, não esperamos que a criança possua espontaneamente um tacto correspondente de forma semelhante. (p. 187, grifo nosso) ${ }^{4}$.

Assim sendo, não é de se esperar que, uma vez estabelecida uma resposta verbal sob dadas condições de estímulos, que a mesma topografia seja emitida em outras condições de estímulos, o que foi denominado por Skinner (1957/1992) de independência funcional entre os operantes verbais.

No entanto, em condições naturais de observação, dificilmente conseguimos analisar o comportamento verbal em operantes verbais e, portanto, dificilmente reconhecemos a independência funcional entre os operantes verbais.

\footnotetext{
${ }^{4}$ In the terminology of meaning, we say that the word doll is used at one time to "ask for a doll" and at other to "describe or refer to a doll". When the response Doll! has been acquired as a mand, however, we do not expect that he child then spontaneously possesses a corresponding tact of a similar form. If we find both in the repertory of the child, we must account for them separately.
} 
Cotidianamente nos deparamos com respostas verbais fluidas e emitidas sob controle de diversas relações entre estímulos. Assim, parece-nos que as palavras têm seu significado próprio (não nos damos conta das relações que elas estabeleceram enquanto tal) e, assim, pode ser fortalecida a errônea concepção da palavra como uma ferramenta ou instrumento, que o homem "usa" para se comunicar. O trecho de Skinner (1957/1992) a seguir ilustra essa idéia

Todavia, uma resposta verbal de uma dada forma às vezes parece passar facilmente de um tipo de operante para outro. O falante comumente começa com um tacto e em seguida parece possuir um mando correspondente. Uma criança numa loja de brinquedos, incapaz de identificar um brinquedo particular, pergunta $O$ que é isso? e lhe respondem Um joão-bobo. Isso é estímulo para uma resposta ecóica ${ }^{5}$ - do tipo usado comumente para reforçar a resposta com um tacto. Mas a criança diz imediatamente Me compra um joão-bobo. Ela nunca fora reforçada a emitir essa resposta de maneira necessária para construir um mando ${ }^{6}$. (p. 188)

Neste exemplo, segundo Skinner, a resposta verbal João bobo em tato, não foi "transferida" espontaneamente para a condição de mando. Para o autor, o que determinou a emissão da resposta em mando foi o comportamento de transcrição ou translação ${ }^{7}$

\footnotetext{
${ }^{5}$ O operante ecóico foi definido por Skinner (1957/1992) como uma resposta verbal emitida sob controle de estímulos verbais cuja topografia de resposta corresponde ponto a ponto ao estímulo discriminativo. A conseqüência que mantém o comportamento ecóico é um reforço generalizado, como no tato (p. 55).

${ }^{6}$ However, a verbal response of given form sometimes seems to pass easily from one type of operant to another. The speaker commonly starts with a tact and then appears to possess a corresponding mand. The child in a toy store, unable to identify a particular toy, asks What is that? And is told $A$ doodler. This is a stimulus for an echoic response - of the sort which is then commonly used to reinforce the response as a tact. But the child immediately says Buy me a doodler! He has never been reinforced for this response in the manner required to construct a mand.

7 Transcription ou translation.
} 
O comportamento de "perguntar pela palavra necessária para pedir um brinquedo" é um mando reforçado (e assim especificado) pelo comportamento auditivo da parte do ouvinte, o qual, quando repetido, produz caracteristicamente, o brinquedo (p. $188-189)^{8}$.

Skinner, 1957/1992, especificou mais duas condições em que uma resposta ensinada em tato seja emitida na condição de mando e vice-versa. A primeira delas diz respeito aos eventos ambientais que reforçam a emissão de um mando; frequentemente os estímulos reforçadores produzidos pela resposta verbal em mando se assemelham aos estímulos discriminativos que controlam um tato ( $p$. 189). Outra condição possível "pode surgir do fato de que a presença de um objeto reforçador é uma condição ótima para o reforço" ${ }^{9 »}$ (p. 189). Assim, configura-se a aquisição ou a emissão de uma resposta sob controle dos estímulos que determinam ambos os operantes, tato e mando.

Por fim, Skinner (1958/1992) defende que

Classificações de respostas são úteis apenas na separação de vários tipos de relações de controle, e algumas respostas podem apresentar traços tanto de mando quanto de tato. De qualquer forma, temos que conhecer a história de uma forma particular de resposta e de todas as variáveis que adquiriram controle sobre ela. ... Se não há desenvolvimento espontâneo de um tipo de operante como resultado da montagem de outro, então o único problema que surge a partir da presença da mesma forma em operantes de diferentes tipos é um problema relacionado com a comunidade verbal. A "palavra", como unidade de análise, é mais apropriada às

\footnotetext{
8 The behavior of "asking for the word needed to ask for a toy" is a mand reinforced by (an hence specifying) auditory behavior on the part of the listener witch, when echoed, characteristically produces the toy.

${ }^{9}[\ldots]$ may arise from the fact that the events which reinforce a mand often resemble the discriminative stimuli which control a tact.
} 
práticas da comunidade do que o comportamento de cada falante (p. 189-190, grifo nosso $)^{10}$.

Assim sendo, de acordo com Skinner (1957/1994) não existe necessariamente transferência de relações de controle de um operante verbal para outro. Se considerássemos a existência do fenômeno da transferência de funções, estaríamos perpetuando a crença dos lingüistas de que as palavras têm seu significado a despeito da ocasião na qual são emitidas. O que existe, para Skinner, é o estabelecimento de respostas verbais sob controle de relações variadas entre estímulos, como citado no exemplo do João-bobo, sendo que, em diferentes instâncias algumas variáveis são mais (ou menos) relevantes na determinação das respostas verbais do que outras. Assim, se quisermos explicar o porquê de uma dada topografia ensinada em mando, por exemplo, ser emitida também na condição de tato (sem, aparentemente, ter sido ensinada para tanto), temos que olhar para a história de aquisição dessa resposta, para as relações de controle entre estímulos que estiveram presentes (e controlando a resposta) durante a aquisição da mesma.

Alguns autores vêm estudando, com procedimentos controlados, a independência funcional dos operantes verbais tato e mando (Lamarre \& Holland, 1985; Hall \& Sundberg, 1987; Sigafoos, Doss \& Reichle, 1989; Sigafoos, Reichle, Doss Hall e Pettitt, 1990; Twyman, 1996; Wallace, Iwata \& Hanley, 2006; Alves \& Ribeiro, 2007; Ziomek \& Rehfeldt, 2008).

10 Classifications of responses are useful only in separating various types of controlling relations, and some responses may show features of both mand and tact. In any case, we have to know the history of a particular form of response and of all the variables which have acquired control of it. ... If there is no spontaneous development of one type of operant as the result of setting another, then the only problem arising from the presence of the same form in operants of different types is a problem concerning the verbal community. The "word" as a unit of analysis is appropriate to the practices of the community rather than the behavior of the individual speaker. 
O primeiro grande marco do estudo da independência funcional entre os operantes tato e mando com humanos foi o experimento conduzido por Lamarre e Holland (1985), que teve o seguinte objetivo:

O presente estudo investigou as relações entre mandos e tatos que têm uma mesma forma de resposta. O estudo foi delineado para examinar a suposição de que um operante verbal não aparece simplesmente como resultado do estabelecimento de outro, com a mesma forma de resposta (p.7 $)^{11}$.

Neste experimento, os autores investigaram a relação entre mandos e tatos envolvendo as topografias de respostas à direita e à esquerda, com crianças préescolares. Nove crianças (três meninos e seis meninas, de idade média variando entre 3 anos e 5 meses a 5 anos) foram selecionadas a participar do estudo.

Os participantes foram divididos em dois grupos. Para cada grupo foi delineada uma seqüência específica de treinos verbais e testes de tato e mando, conforme é apresentado na Tabela 1. O Grupo 1 (4 participantes) iniciou o treino na condição de mando, e o Grupo 2 (5 participantes) iniciou o treino na condição de tato.

O estudo foi iniciado com o desenvolvimento de comportamentos prérequisitos, a saber: (a) apontar um objeto específico frente ao nome ditado pelo experimentador; (b) emitir tatos de objetos e; (c) frente à verbalização à direita e/ou à esquerda emitida pelo experimentador, o participante deveria comportar-se como um ouvinte, ou seja, deveria colocar um dado objeto à esquerda ou à direita de um outro objeto.

\footnotetext{
11 The present study investigated the relation of mands and tacts that have the same response form. It was designed to examine the claim that one verbal operant does not appear simply as the result of establishing another with the same response form.
} 
TABELA 1

Seqüencias dos Treinos e Testes do Estudo de Lamarre e Holland (1985)

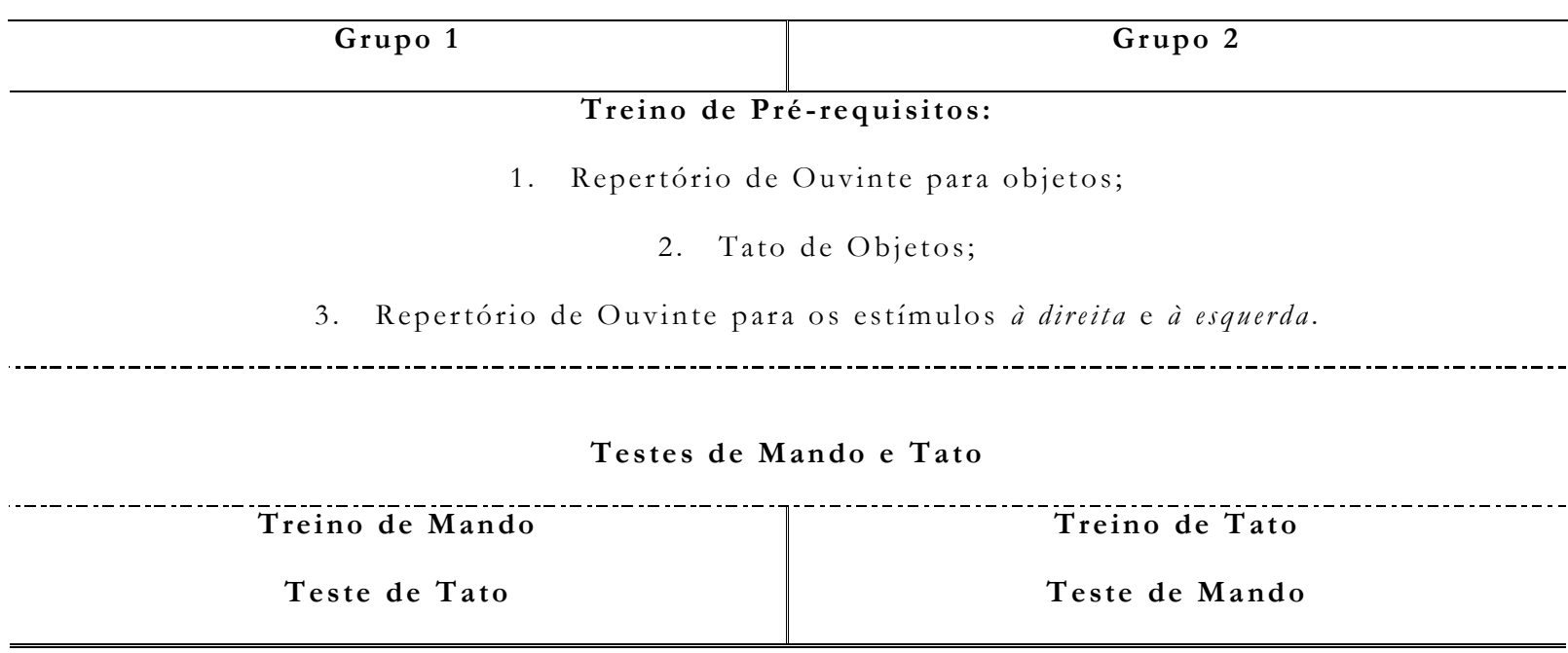

Treino de Pré-requisitos:

1. Repertório de Ouvinte para objetos;

2. Tato de Objetos;

Treino de Tato

Teste de Manutenção do Mando
Treino de Mando

Teste de Manutenção do Tato

\title{
Treino de Pré-Requisitos:
}

1. Repertório de Ouvinte para objetos;

2. Tato de Objetos;

\author{
Treino de Mando Reverso \\ Teste de Tato Reverso
}

\begin{abstract}
Treino de Tato Reverso
Teste de Mando Reverso
\end{abstract}

A emissão de tatos e mandos foi testada antes e depois do Treino de Tato/Mando por oito tentativas: quatro tentativas na condição de mando e quatro tentativas na condição de tato.

Cada tentativa de teste e treino era iniciada com a apresentação de dois objetos. No caso do mando, um objeto estava com o experimentador e o outro sobre a mesa e, no caso do tato, os dois objetos estavam sobre a mesa. Além disso, o experimentador emitia a questão Onde você quer que eu coloque esse objeto? (quando em mando), ou Onde está o objeto? (quando em tato). Apenas nas 
tentativas de treino, o experimentador apresentava, quando necessário, a resposta modelo (dica ecóica ${ }^{12}$ - Diga à esquerda, por exemplo) para que o participante ecoasse/repetisse em seguida.

Não havia conseqüências programadas para o responder (ou para a não emissão de respostas) dos participantes nos testes. Já nas tentativas de treino, a conseqüência prevista para o responder dos participantes em tato era a apresentação de um reforçador generalizado. Nas tentativas de mando, o experimentador colocava o objeto na posição solicitada pelo participante (se o experimentador colocasse o objeto na posição solicitada pelo participante, o experimentador recebia uma bolinha de gude do mesmo ${ }^{13}$ ). Na Tabela 2 são descritos os estímulos antecedentes e conseqüentes às respostas dos participantes nos treinos.

O treino de ambos os operantes verbais ocorriam com pares de objetos. O critério definido por Lamarre e Holland (1985) para aplicar o Treino de Mando para um novo par de objetos era que o participante respondesse por oito tentativas consecutivas corretas à pergunta Onde você quer que eu coloque o objeto?/ Onde está este... (objeto)? (incluindo as respostas de falar não, diante do erro do experimentador, nas tentativas de mando). Já o critério para finalizar a condição experimental de treino das topografias em mando ou tato era de que o participante emitisse respostas corretas com cinco pares de objetos nunca utilizados, sem a necessidade de treino.

\footnotetext{
12 Um comportamento verbal, para ser denominado de ecóico, deve apresentar um estímulo antecedente verbal oral, uma resposta verbal oral idêntica ao estímulo antecedente, ou seja, esta resposta deve corresponder ponto a ponto com o estímulo verbal anteriormente apresentado e uma conseqüência reforçadora generalizada. Por exemplo, nós brasileiros, ao aprender o inglês, somos expostos a contingências, nas quais devemos repetir as palavras pronunciadas pelos professores da mesma maneira que o modelo por eles apresentados: o professor verbaliza toy, nós repetimos toy. Repetir toy é um exemplo de operante ecóico.

13 A cada quatro mandos emitidos pelo participante, em média, o experimentador respondia de maneira errada, colocando o objeto em outra posição, que não a solicitada pelo participante. O participante, por sua vez, deveria corrigir o experimentador.
} 
Os procedimentos dos Treinos Reversos foram idênticos aos anteriores, com uma exceção: ocorreu uma inversão na disponibilização do reforço, ou seja, se antes o participante era reforçado a verbalizar à direita, frente à localização espacial de um objeto à direita e a verbalizar à esquerda, frente à localização espacial de um objeto à esquerda; na condição de tato reverso ele será reforçado a verbalizar à esquerda, quando o objeto estiver localizado à direita e vice-versa. O mesmo ocorreu no mando reverso.

TABELA 2

Eventos Antecedentes e Conseqüentes às Respostas Treinadas nas Condições de Tato e Mando (Lamarre \& Holland, 1985)

\begin{tabular}{|c|c|c|c|c|c|}
\hline \multicolumn{2}{|c|}{ Eventos Antecedentes } & \multicolumn{2}{|c|}{ Resposta Comum } & \multicolumn{2}{|c|}{$\begin{array}{c}\text { Conseqüências previstas nos } \\
\text { treinos }\end{array}$} \\
\hline MANDO & TATO & MANDO & TATO & MANDO & TATO \\
\hline $\begin{array}{l}\text { Dois objetos: } \\
\text { um sobre à } \\
\text { mesa e outro } \\
\text { nas mãos do } \\
\text { experimentador }\end{array}$ & $\begin{array}{l}\text { Dois objetos } \\
\text { sobre à mesa. }\end{array}$ & \multirow{3}{*}{\multicolumn{2}{|c|}{$\begin{array}{l}\text { Topografia comum: } \\
\text { à direita e à esquerda }\end{array}$}} & $\begin{array}{l}\text { O experimentador } \\
\text { colocava o objeto na } \\
\text { posição solicitada. } \\
\text { A cada quatro } \\
\text { tentativas (em } \\
\text { média), o } \\
\text { experimentador } \\
\text { colocava o objeto na } \\
\text { posição errada. }\end{array}$ & $\begin{array}{c}\text { Reforço } \\
\text { generalizado }\end{array}$ \\
\hline $\begin{array}{l}\text { exper } \\
\text { qude vocề quer } \\
\text { esse objeto? }\end{array}$ & $\begin{array}{l}\text { mitida pelo } \\
\text { entador: } \\
\text { Onde está o objeto } \\
\text { obome do } \\
\text { objeto)? }\end{array}$ & & & $\begin{array}{l}\text { Entregar uma } \\
\text { bolinha de gude para } \\
\text { o experimentador. }\end{array}$ & --- \\
\hline $\begin{array}{r}\text { Dicas ecóic } \\
\text { exper }\end{array}$ & $\begin{array}{l}\text { emitidas pelo } \\
\text { entador. }\end{array}$ & & & & \\
\hline
\end{tabular}


Os resultados descritos no estudo de Lamarre e Holland (1985) são apresentados a seguir:

1. Todos os participantes se comportaram como ouvintes diante das instruções coloque à direita e coloque à esquerda (Treino de Pré-Requisitos);

2. Todos os participantes atingiram o critério de aprendizagem nos treinos dos operantes verbais tanto na primeira condição de treino quanto nos Treinos Reversos.

3. Após o Treino de Mando e Tato, nenhum dos participantes emitiu respostas verbais nos testes do operante não diretamente treinado.

5. Apenas um participante do Grupo 1 emitiu tatos reverso (não diretamente treinados), nos testes, após o Treino de Mando Reverso.

6. Dois participantes do Grupo 2 emitiram mandos reversos (não diretamente treinados), após o Treino de Tato Reverso.

Lamarre e Holland (1985) concluíram que os resultados apresentados sugerem independência funcional em duas condições: (a) entre o repertório de ouvinte (instalado no Treino de Pré-Requisitos) e o repertório de falante (Testes iniciais de Tato e Mando) e (b) entre tato e mando de mesma topografia (demonstrado pelos resultados dos treinos e testes dos mesmos operantes).

Em relação à emissão das respostas reversas não diretamente treinadas, mas emitidas nos testes finais, Lamarre e Holland (1985) sugeriram que tais respostas foram emitidas como produto da história experimental dos participantes. Dito de outro modo, as contingências de instalação de tatos e mandos, conforme propostas no estudo, parecem explicar a emissão das respostas não diretamente treinadas (ou, nas palavras dos autores, desenvolvimento do tato/mando colateral). Os autores destacaram que os estímulos envolvidos nos treinos, como a posição dos objetos e as perguntas emitidas pelo 
experimentador, eram semelhantes tanto em tato quanto em mando e, portanto, esperava-se que o treino de um operante (mando ou tato) fosse suficiente para produzir a mesma topografia verbal no operante não diretamente treinado. Os autores apontam essa análise da seguinte forma

De uma certa maneira, é surpreendente que a maioria dos participantes não tenham revertido um operante como resultado do treino reverso do outro, porque a situação na qual o mando foi ensinado tinha muito em comum com a situação na qual o tato fora ensinado. A posição do estímulo que controlou o tato era idêntica a posição do estímulo que reforçou o mando. Também, ambas as frases preposicionais (relativamente não familiares a todos os participantes antes desse estudo) tinham sido ensinadas em tato e em mando antes de uma de suas funções terem sido revertidas ${ }^{14}$ (p.17).

Por fim, os autores enfatizaram as suposições de Skinner (1957) de que o significado das palavras é construído na relação das mesmas com os eventos antecedentes e conseqüentes:

Quando o comportamento verbal é analisado em termos das palavras e de seus significados, a distinção entre os operantes verbais é perdida. Uma criança que pede para alguém colocar alguma coisa à direita e reage apropriadamente às respostas é dita como alguém que conhece o significado da frase. O indivíduo poderia esperar que se a criança for agora solicitada a dizer a posição de um objeto que foi colocado à direita de um outro objeto, a criança poderia responder com a

\footnotetext{
${ }^{14}$ In one respect, it is surprising that the majority of the subjects did not reverse one operant as a result of reversal training with the other, because the situation in which the mand was taught had so much in common with the situation in which the tact was taught. The position of the stimuli that controlled the tact was identical to the position of the stimuli that reinforced the mand. Also, the prepositional phrases (relatively unfamiliar to all subjects prior to this study) had been taught both as tacts and as mands before one of their functions was reversed.
} 
frase "À direita". Se o indivíduo analisar o comportamento verbal em termos de palavras como unidades semânticas, como a maior parte da comunidade verbal o faz, o indivíduo não iria predizer o resultado do presente estudo, mas ao contrário, iria esperar que a palavra fosse "chamada" e usada quando necessário, seja para descrever algo ou pedir algo, ou repetir a verbalização de outro indivíduo ou cumprir uma instrução ${ }^{15}$. (p.18)

Twyman (1996) fez uma replicação sistemática do estudo de Lamarre e Holland (1985), tendo como objetivo investigar a independência funcional de tatos impuros e mandos impuros ${ }^{16}$ de propriedades abstratas de estímulos.

Foram participantes do estudo quatro crianças (dois meninos e duas meninas) com desenvolvimento atípico (atraso na linguagem) em idade préescolar (variando entre 4 anos e 4 meses a 4 anos e 10 meses).

Foi conduzido um delineamento experimental de Linha de Base Múltipla intra-participantes, detalhado na Tabela 3. Cada participante foi exposto a uma seqüência específica de treinos e testes dos operantes tato e mando. Os Participantes 1 e 2 foram inicialmente ensinados a emitir mandos, enquanto os Participantes 3 e 4 foram inicialmente ensinados a emitir tatos.

\footnotetext{
${ }^{15}$ When verbal behavior is analyzed in terms of words and their meanings, the distinction between different verbal operants is lost. A child who tells someone to put something on the right and rewards the responses appropriately is said to know the meaning of the phrase. One would expect that if the child were now asked the position of an object that had been placed on the right of another object, the child would respond with the phrase "On the right." If one analyzed verbal behavior in terms of words as general semantic units, as most of the verbal community does, one would not predict the results of the present study, but rather would expect that the word would be "called up" and used when needed, whether to describe something, to ask for something, to repeat another's utterance, or to comply with an instruction.

16 Tatos e Mandos Impuros foram definidos por Skinner (1957/1992) como sendo respostas emitidas sob controle de múltiplos estímulos. No caso do presente estudo, os Mandos e Tatos Impuros foram controlados por operações estabelecedoras e estímulos discriminativos e/ou conseqüenciadas por um reforço característico e um reforço generalizado: "Um resultado comum é a mistura de relações de controle características tanto de tato, quanto de mando" (Skinner, 1957/1994, p.151).
} 
Cada tentativa de Treino de Mando, bem como cada tentativa de Treino de Tato era iniciada enquanto o participante estivesse engajado em uma atividade (colorir com giz, construir uma casa com legos, montar quebra-cabeça de madeira ou brincar com massinha). O experimentador interrompia a atividade na qual o participante estivesse engajado e:

1) Nas tentativas de Treino de Mando Impuro, o experimentador retirava o item que deveria ser "pedido" (por exemplo, enquanto o participante estava pintando com o giz redondo, o experimentador retirava o giz de suas mãos). Eram apresentados, então, dois itens nas mãos do experimentador: o item a ser "pedido" (giz redondo) e o item "fora de padrão" (por exemplo, pedaço de gi quebrado). O participante deveria emitir o mando do estímulo com sua respectiva propriedade abstrata adicionado ao autoclítico ${ }^{18}$ por favor, em até cinco segundos da apresentação dos itens. O mando era consequenciado com o item necessário para a continuidade da atividade.

3) Nas tentativas de Treino de Tato Impuro, o experimentador solicitava que o participante olhasse para o experimentador, verbalizando olhe para mim ou colocava as mãos em cima da atividade. Em seguida, o experimentador apresentava sobre a mesa um dos quatro itens (giz redondo, massinha macia, quebracabeça de madeira ou lego grande) e o item fora de padrão e apontava para o item em relação ao qual o tato deveria ser emitido.

\footnotetext{
17 "Non-exemplar".

18 A resposta por favor foi categorizada pelo autor como sendo um operante verbal autoclítico. O autoclítico foi definido por Skinner como um comportamento verbal que descreve um outro comportamento verbal, produzindo um efeito importante e característico sobre o ouvinte, modificando a reação do ouvinte ao comportamento verbal do falante. No caso do estudo de Twyman (1996), a verbalização por favor, aumentava a chance do ouvinte reagir ao mando do participante (p.377).
} 
TABELA 3

Seqüencias dos Testes e Treinos do Estudo de Twyman (1996)

\begin{tabular}{|c|c|c|c|}
\hline Participante 1 & Participante 2 & Participante 3 & Participante 4 \\
\hline \multicolumn{4}{|c|}{$\begin{array}{c}\text { Testes de Mando e Tato, para os objetos giz, massinha, quebra-cabeça e lego } \\
\text { Testes de Mando e Tato, para as propriedades abstratas: giz redondo, massinha macia, quebra-cabeça d } \\
\text { madeira e lego grande. }\end{array}$} \\
\hline $\begin{array}{c}\text { Treino de Mando } \\
\text { Impuro } \\
\text { Teste de Tato } \\
\text { Estímulo: giz redondo }\end{array}$ & $\begin{array}{c}\text { Treino de Mando } \\
\text { Impuro } \\
\text { Teste de Tato } \\
\text { Estímulo: lego grande }\end{array}$ & $\begin{array}{c}\text { Treino de Tato } \\
\text { Impuro } \\
\text { Teste de Mando } \\
\text { Estímulo: quebra-cabeça } \\
\text { de madeira }\end{array}$ & $\begin{array}{c}\text { Treino de Tato } \\
\text { Impuro } \\
\text { Teste de Mando } \\
\text { Estímulo: massinba } \\
\text { macia } \\
\end{array}$ \\
\hline $\begin{array}{l}\text { Treino de Tato } \\
\text { Impuro } \\
\text { Estímulo: giz redondo }\end{array}$ & $\begin{array}{l}\text { Treino de Tato } \\
\text { Impuro } \\
\text { Estímulo: lego grande }\end{array}$ & $\begin{array}{c}\text { Treino de Mando } \\
\text { Impuro } \\
\text { Estímulo: quebra-cabeça } \\
\text { de madeira }\end{array}$ & $\begin{array}{c}\text { Treino de Mando } \\
\text { Impuro } \\
\text { Estímulo: massinba } \\
\text { macia }\end{array}$ \\
\hline \multicolumn{4}{|c|}{$\begin{array}{l}\text { Teste de Mando e Tato } \\
\text { assinha macia, quebra-cabeça de madeira e lego grande. }\end{array}$} \\
\hline $\begin{array}{c}\text { Treino de Tato } \\
\text { Impuro } \\
\text { Teste de Mando } \\
\text { Estímulo: massinba } \\
\text { macia } \\
\end{array}$ & $\begin{array}{c}\text { Treino de Tato } \\
\text { Teste de Mando } \\
\text { Estímulo: quebra-cabeça } \\
\text { de madeira }\end{array}$ & $\begin{array}{c}\text { Treino de Mando } \\
\text { Impuro } \\
\text { Teste de Tato } \\
\text { Estímulo: giz redondo }\end{array}$ & $\begin{array}{c}\text { Treino de Tato } \\
\text { Impuro } \\
\text { Teste de Mando } \\
\text { Estímulo: lego grande }\end{array}$ \\
\hline & $\begin{array}{l}\text { Treino de Mando } \\
\text { Estímulo: quebra-cabeça } \\
\text { de madeira }\end{array}$ & $\begin{array}{c}\text { Treino de Tato } \\
\text { Impuro } \\
\text { Estímulo: giz redondo }\end{array}$ & $\begin{array}{c}\text { Treino de Mando } \\
\text { Impuro } \\
\text { Estímulo: lego grande }\end{array}$ \\
\hline
\end{tabular}

Teste de Mando e Tato

Estímulos: giz redondo, massinha macia, quebra-cabeca de madeira e lego grande.

\begin{tabular}{|c|c|c|c|}
\hline $\begin{array}{c}\text { Treino de Mando } \\
\text { Impuro } \\
\text { Teste de Tato } \\
\text { Estímulo: quebra-cabeça } \\
\text { de madeira }\end{array}$ & ---- & ---- & ---- \\
\hline $\begin{array}{c}\text { Treino de Tato } \\
\text { Impuro } \\
\text { Estímulo: quebra-cabeça } \\
\text { de madeira }\end{array}$ & ---- & ---- & ---- \\
\hline $\begin{array}{l}\text { Teste de Mando e Tato } \\
\text { Estímulos: giz redondo, } \\
\text { massinba macia, quebra- } \\
\text { cabeça de madeira e lego } \\
\text { grande. }\end{array}$ & ---- & ---- & ---- \\
\hline $\begin{array}{c}\text { Treino de Tato } \\
\text { Impuro } \\
\text { Teste de Mando } \\
\text { Estímulo: lego grande }\end{array}$ & ---- & ---- & ---- \\
\hline $\begin{array}{c}\text { Treino de Mando } \\
\text { Impuro } \\
\text { Estímulo: lego grande }\end{array}$ & ---- & ---- & ---- \\
\hline $\begin{array}{l}\text { Teste de Mando e Tato } \\
\text { Estímulos: giz redondo, } \\
\text { massinba macia, quebra- } \\
\text { cabeça de madeira e lego } \\
\text { grande. }\end{array}$ & ---- & ---- & ---- \\
\hline
\end{tabular}

Nota. Os Participantes 2, 3 e 4 só foram ensinados a emitir as respostas verbais com dois estímulos, pois, segundo os autores, os mesmos apresentaram "Presença pouco freqüente e o final do ano letivo dificultou a conclusão das quatro condições pelos Estudantes 2 -4 ${ }^{19}$ " (Twyman, 1996, p.8).

19 "Infrequent attendence and the end of the school year hampered the completion of all four conditions for Students 2-4". 
As primeiras tentativas dos Treinos de Tato e Mando eram realizadas com dica ecóica, ou seja, o experimentador emitia a resposta para o participante repetir. Após a emissão de três respostas com dica ecóica, as tentativas seguintes eram apresentadas sem dica. Se o participante emitisse o tato/mando do objeto com a propriedade abstrata, o experimentador o elogiava e disponibilizava a atividade por mais cinco segundos. Seguia-se, então, o intervalo entre tentativas. Caso o participante não emitisse a resposta verbal, o experimentador perguntava "o que é isso?" (na contingência de tato) ou "o que você quer?”, quando na contingência de mando. Se, ainda assim, o participante não respondesse após cinco segundos da emissão da pergunta ou se ele emitisse erros, o participante perdia o acesso à atividade por cinco segundos. Caso o participante emitisse apenas o tato ou mando do objeto (sem a propriedade abstrata), o experimentador apontava para o estímulo "fora de padrão", no caso do tato e entregava o item fora do padrão, quando em mando. Na Tabela 4 é apresentado os estímulos envolvidos em cada um dos operantes treinados.

O critério de aquisição do repertório de tato impuro ou mando impuro para uma dada propriedade de estímulo abstrato foi de dez respostas corretas em dez tentativas, por duas vezes (ou sessões) consecutivas. O mesmo critério foi estabelecido para dizer que os participantes emitiram com consistência o operante não diretamente treinado nos testes (segundo o autor, Teste de Generalização ${ }^{20}$.

Antes de cada treino, conforme apresentado na Tabela 3, o participante era exposto às condições de teste, para verificar a emissão (ou não) de tatos e mandos para os quatro estímulos. Os testes eram realizados como descrito nas tentativas de treino, os acertos também eram conseqüenciados, mas não

20 "A generalization criterion was achieved when the student specified the target abstract stimulus property for 10 out of 10 trials in the untrained operant” (p.10). 
ocorriam as dicas ecóicas. Erros ou não respostas foram ignorados por três segundos, até uma nova tentativa ser apresentada.

TABELA 4

Eventos Antecedentes e Conseqüentes às Respostas de Tato e Mando no estudo de Twyman (1996)

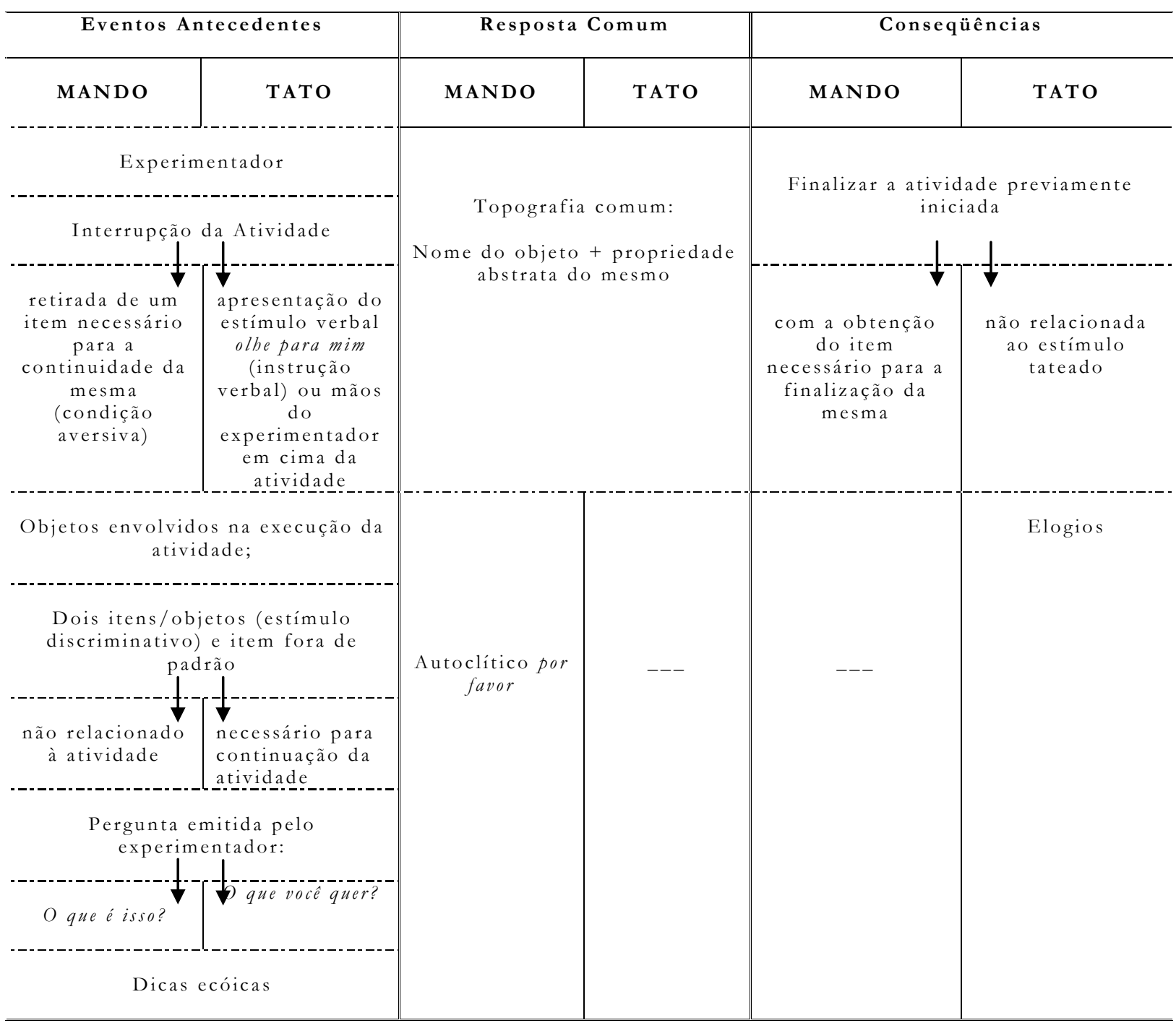

Os resultados do estudo de Twyman (1996) apontaram que todos os participantes atingiram critério de aprendizagem dos operantes tato impuro e 
mando impuro, especificando as propriedades do estímulo, quando treinados diretamente para tanto.

Em relação aos Treinos de Mando/Tato, o Participante 1 precisou de relativamente o mesmo número de tentativas de treino para atingir o critério de aprendizagem nos dois operantes. Nos testes, por outro lado, o Participante 1 emitiu mais respostas corretas nas tentativas de mando do operante não diretamente treinado. Os Participantes 2 e 3 emitiram mais respostas corretas no treino de mando. O Participante 4, por sua vez, emitiu um maior número de respostas corretas em tato e precisou de menos tentativas de treino para atingir o critério de aprendizagem no treino de tato, quando comparado com seu desempenho em mando.

Nos testes, apenas o Participante 1 atingiu o critério de generalização, no Teste de Mando para massinha macia.

Twyman (1996) discutiu que seus resultados estendem os achados da literatura de independência funcional entre os operantes verbais tato e mando que especificam as propriedades abstratas dos estímulos.

Twyman (1996) aponta, ainda, que o fato dos participantes, na história prévia, emitirem tatos e mandos de objetos concretos (sem a propriedade abstrata dos mesmos) parece não ter interferido na emissão dos operantes tato de objetos com suas respectivas propriedades abstratas, bem como do mando de objetos com suas respectivas propriedades abstratas, sem treino direto.

Por fim, pode-se dizer que os Treinos de Tato e Mando Impuros que envolviam, respectivamente, variáveis relacionadas a mando e tato também não parece ter interferido na emissão dos operantes não diretamente treinados. 
Embora Twyman (1996) supusesse que o treino de mando com a presença do estímulo discriminativo (de tato) pudesse facilitar a aquisição do tato (da mesma topografia), esta suposição confirmou-se apenas para o Participante 4.

Os resultados encontrados por Twyman (1996), bem como a interpretação de seus dados, corroboram a posição de Skinner (1957) em relação a independência funcional dos operantes verbais e, ainda, explicam os resultados em relação à emissão dos operantes não diretamente treinados, especialmente nos casos dos Particpantes 1 e 4.

Hall e Sundberg (1987) também conduziram um estudo que buscou identificar a independência funcional entre tatos e mandos. O Treino de Mando foi realizado com controle das operações estabelecedoras via procedimento de Interrupção de Cadeia. Esse procedimento favorece que o Treino de Mando ocorra sob controle dos estímulos de mando em sua forma mais pura (ou seja, sem a presença do estímulo discriminativo e sem a presença do intraverbal o que você quer?).

O estudo de Hall e Sundberg (1987) buscou responder às seguintes questões:

1) Se mandos poderiam ser ensinados em ambientes estruturados, possibilitando ao experimentador controlar a topografia a ser treinada com a manipulação das operações estabelecedoras;

2) Se o Treino de Mando com a manipulação de operações estabelecedoras produziria mandos generalizados (se mandos não treinados ocorreriam na presença dos mesmos ou de novos controles de estímulos ou mandos treinados ocorreriam sob novos controles de estímulos);

3) Se, ao estabelecer certas topografias na condição de tato, as mesmas topografias poderiam ser emitidas na condição de mando. 
4) Caso o estabelecimento de tatos não fosse suficiente para produzir mandos, qual procedimento seria mais efetivo para o Treino de Mando. O procedimento com dica imitativa ou o procedimento com dica de tato?

Participaram da pesquisa dois indivíduos surdos e diagnosticados como deficientes mentais, sendo um do sexo masculino, com 16 anos de idade (Participante 1) e outro do sexo feminino, com 17 anos de idade (Participante 2). Os participantes foram selecionados por emitirem pouca variabilidade de mandos e os mesmos eram emitidos em uma freqüência baixa. Além disso, os mandos nunca haviam sido emitidos sem a presença do estímulo discriminativo.

As respostas verbais estudadas eram da Linguagem de Sinais Americana.

Antes da introdução das variáveis experimentais, os participantes foram expostos ao Pré-Treino no qual cada participante foi ensinado a:

1) Completar quatro cadeias comportamentais que produziam um reforçador. $\mathrm{Na}$ Tabela 5 apresentam-se as cadeias comportamentais desenvolvidas com os Participantes 1 e 2.

2) Emitir tatos de todos os itens necessários para a execução de cada cadeia comportamental. Nessa condição, o experimentador apresentava um objeto/item para o participante e emitia a resposta na linguagem de sinais $O$ que é isso?. O participante, por sua vez, deveria emitir uma resposta de tato do item previamente apresentado. As respostas corretas eram conseqüenciadas com fichas (estímulo reforçador condicionado, que poderia ser trocado, posteriormente, por itens reforçadores). Se o participante não emitisse o tato correto, o experimentador apresentava o modelo da resposta e reapresentava o objeto/item, para que o participante emitisse novamente o tato. Este procedimento ocorreu até que o participante emitisse o tato correto em 100\% das tentativas, por duas sessões consecutivas. 
TABELA 5

Cadeias Comportamentais Desenvolvidas no Experimento de Hall e Sundberg (1987)

\begin{tabular}{|c|c|c|}
\hline & Participante 1 & Participante 2 \\
\hline Cadeia 1 & \multicolumn{2}{|c|}{ Fazer sopa instantânea } \\
\hline Objetos & \multicolumn{2}{|c|}{ Sopa instantânea, água quente, vasilha e colher } \\
\hline Tarefas & $\begin{array}{r}\text { 2. Colocar } \\
\text { 3. Coloca } \\
4 . \mathrm{M} \\
\text { 5. Tomar a }\end{array}$ & $\begin{array}{l}\text { opa na vasilha; } \\
\text { gua quente; } \\
\text { r a sopa; } \\
\text { a com a colher. }\end{array}$ \\
\hline Cadeia 2 & Abrir um & ata de frutas \\
\hline Objetos & Lata, abridor d & s, vasilha e colher \\
\hline Tarefas & $\begin{array}{l}\text { 2. Abrir a lata; } \\
\text { 3. Colocar as frutas na vasilha; } \\
\text { 4. Comer as frutas com a colher }\end{array}$ & $\begin{array}{l}\text { 1. Pegar o abridor de latas; } \\
\text { 2. Abrir a lata; } \\
\text { 3. Colocar as frutas na vasilha; } \\
\text { 4. Comer as frutas com a colher }\end{array}$ \\
\hline Cadeia 3 & Secar água da mesa & Fazer café instantâneo \\
\hline Objetos & Água e papel toalha & $\begin{array}{l}\text { Café instantâneo, água quente, xícara } \\
\text { e colher }\end{array}$ \\
\hline Tarefas & $\begin{array}{l}\text { 1. Pegar o papel toalha; } \\
\text { 2. Secar a água. }\end{array}$ & $\begin{array}{l}\text { 2. Pegar uma colher de chá de café; } \\
\text { 3. Colocá-la na xícara; } \\
\text { 4. Colocar a água quente na xícara; } \\
\text { 5. Mexer o café com a colher }\end{array}$ \\
\hline Cadeia 4 & $\begin{array}{l}\text { Operar uma máquina de auto- } \\
\text { vendas }\end{array}$ & Colorir uma figura grande \\
\hline Objetos & Máquina de auto-vendas e dinheiro & $\begin{array}{l}\text { Figura grande parcialmente colorida } \\
\text { e canetas coloridas }\end{array}$ \\
\hline Tarefas & $\begin{array}{l}\text { 2. Colocá-la no local apropriado; } \\
\text { 3. Pressionar o botão; } \\
\text { 4. Pegar o doce. }\end{array}$ & $\begin{array}{l}\text { 1. Pegar uma caneta de um pote; } \\
\text { 2. Colorir uma pequena parte da } \\
\text { figura. }\end{array}$ \\
\hline
\end{tabular}

Nota. Os itens em negrito foram aqueles disponibilizados como conseqüencia das respostas emitidas em mando (eram os itens "pedidos" pelos participantes).

Na Tabela 6, são apresentados os estímulos presentes no Treino de Tato. 
TABELA 6

Estímulos Envolvidos na Contingência de Treino de Tato do Pré-Treino, no

Experimento de Hall e Sundberg (1987)

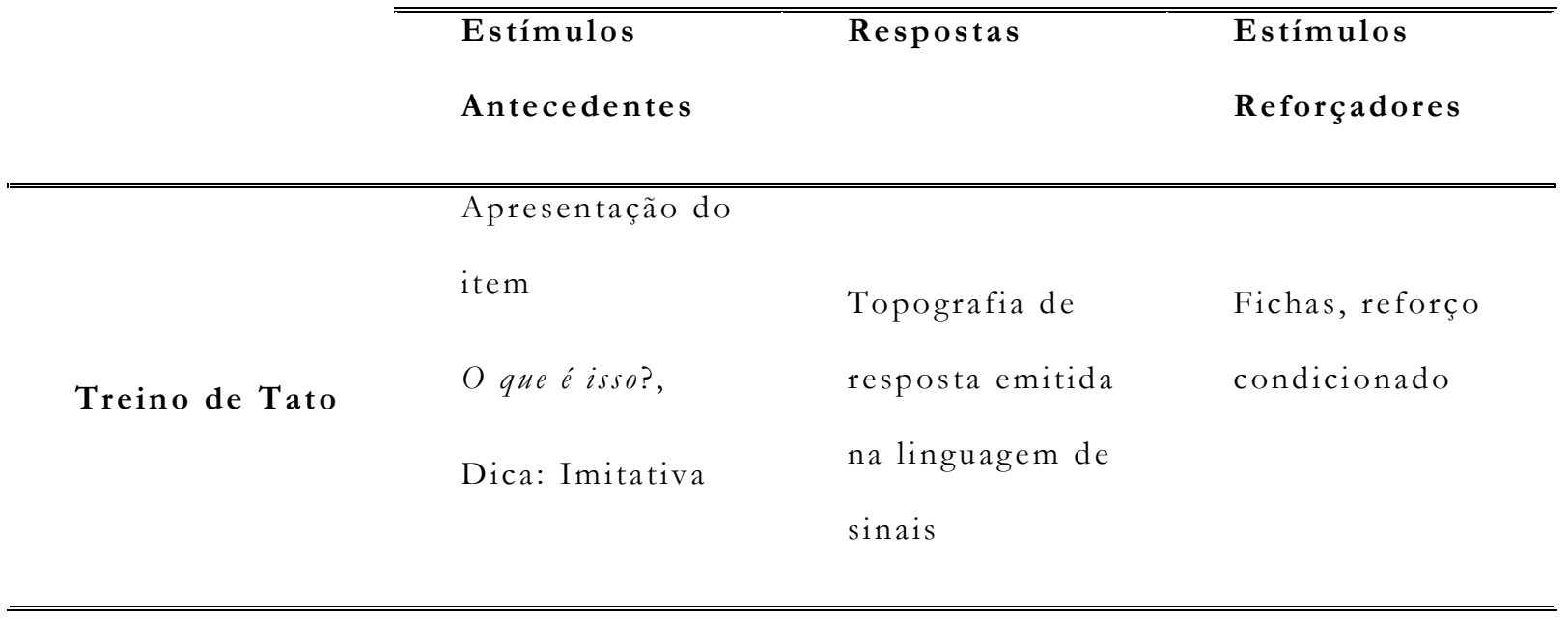

Uma vez realizado o Pré-Treino, Sundberg e Partington (1987) utilizaram um delineamento de Linha de Base Múltipla, entre participantes e entre comportamentos, com múltiplos elementos (dica imitativa e dica de tato, explicados adiante).

Cada participante foi ensinado a emitir mandos com dois pares de estímulos, sendo treinado um par de estímulos por vez, ou seja, primeiro foi ensinado aos participantes emitir mandos com o Par 1 e só então ensinou-se aos participantes a emitir tatos com o Par 2.

O Participante 1, por sua vez, foi ensinado a emitir mandos para os dois pares de estímulos, antes do Participante 2 (enquanto o Participante 1 estava sendo treinado em Tato para o par 1, o Participante 2 estava na condição de Linha de Base e, quando o Participante 1 iniciou o treino do Par 2, o Participante 2 iniciou o reino do Par 1). 
Por fim, os estímulos que compunham cada par de mando eram ensinados simultaneamente: um estímulo do par era ensinado na condição de mando com dica imitativa e o outro estímulo era ensinado na condição de mando com dica de tato.

$\mathrm{Na}$ Tabela 7, apresentam-se as seqüências dos Treinos e Testes de Mando e Tato realizadas com cada um dos participantes.

$\mathrm{Na}$ Linha de Base, o experimentador dispunha para os participantes todos os objetos necessários para a execução da cadeia comportamental, com exceção de um item e emitia a resposta verbal Faça sopa, se esse fosse o caso. O participante iniciava a execução da cadeia comportamental, mas, agora, com um item faltando. No momento em que o participante fosse utilizar o item que faltava, o experimentador não oferecia qualquer tipo de ajuda por um período de 10 segundos. Se o participante emitisse um mando em relação ao item ausente, o item era apresentado e o participante finalizava, então, a execução da cadeia. Nesta condição experimental, se nenhuma resposta fosse emitida, ou se o participante emitisse qualquer outra resposta que não o mando do item, todos os itens eram removidos e outros (de uma nova cadeia) eram apresentados. Assim, não havia nenhuma conseqüência programada para qualquer que fosse a resposta do participante (correta ou incorreta).

O procedimento de Treino de Mando ocorria de maneira similar ao procedimento da Linha de Base. Os itens de cada cadeia comportamental eram apresentados ao participante, com exceção de um item. No momento em que o participante precisasse do item ausente para finalizar a cadeia, se o participante não emitisse o mando (independentemente) em até 10 segundos, o experimentador disponibilizava as dicas de respostas (de tato ou imitativa). 
TABELA 7

Seqüências Intra Participantes e Entre Participantes dos Treinos e Testes de Mando no Experimento de Hall e Sundberg (1987)

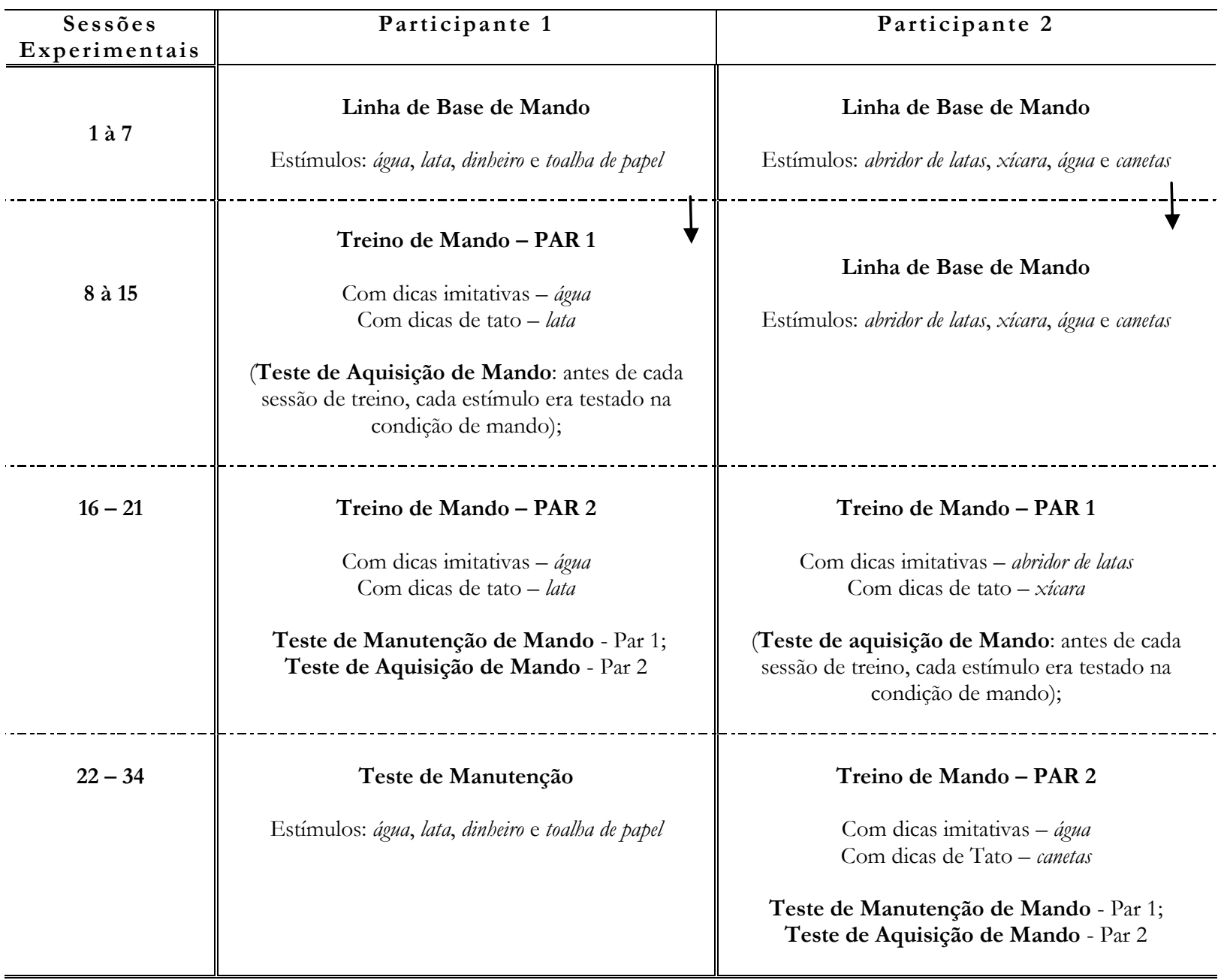

No Treino de Mando com dica de tato, o experimentador apresentava o estímulo discriminativo (item que estava ausente) para o participante e emitia a resposta verbal em linguagem de sinais $O$ que é isso?. O participante, por sua vez, deveria emitir o tato. Se o tato não fosse emitido pelo participante, o experimentador emitia o tato do item (isto é, a resposta modelo) e, em seguida, reapresentava a pergunta $O$ que é isso?. Uma vez emitido o tato pelo participante, o experimentado deixava o item próximo ao mesmo e perguntava $O$ que você 
quer?. O participante deveria emitir a topografia verbal, parte sob controle dos estímulos antecedentes de mando e parte sob controle do estímulo discriminativo do tato. Tendo emitido a topografia verbal sob controle das operações estabelecedoras e estímulos discriminativos, o experimentador retirava todos os itens da mesa e, passados cinco segundos, reapresentava-os, para que o participante emitisse, por fim, o mando sem dicas. Se assim ocorresse, então, era disponibilizado o item reforçador (que estava ausente) ao participante.

No Treino de Mando com dica imitativa o experimentador, no momento do participante utilizar o item ausente, dizia Faça isso, enquanto gesticulava, em linguagem de sinais, o nome do item. Após a emissão de uma resposta imitativa correta, o experimentador fazia o sinal $O$ que você quer? e esperava que o participante emitisse a resposta correta. Se, ainda assim, a resposta correta não ocorresse, o experimentador ajudava fisicamente o participante a emitir a resposta de mando. Para que o participante fosse consequenciado com a aquisição do item, o mesmo deveria emitir a resposta de mando, sem as dicas do experimentador, após a pergunta $O$ que você quer?.

Nota-se que as respostas de mando emitidas com dicas eram sempre conseqüenciadas com fichas. As respostas de mando, emitidas sem qualquer dica, eram conseqüenciadas pela apresentação do item.

Na Tabela 8 apresentam-se os estímulos envolvidos na contingência de treino de mando com dica de tato e com dica imitativa.

Após os participantes atingirem o critério de aprendizagem nos treinos (dois mandos consecutivos emitidos sem dica de resposta), foram conduzidos os Testes de Generalização. Nestes testes, os experimentadores verificaram se, 
frente a diferentes itens e frente a uma topografia de mando nunca treinada, o participante emitia um novo mando.

TABELA 8

Estímulos Envolvidos na Contingência de Treino de Mando com Dica de Tato e Dica Imitativa, no Experimento de Hall e Sundberg (1987)

\begin{tabular}{|c|c|c|}
\hline $\begin{array}{l}\text { Elementos do } \\
\text { Comportamento }\end{array}$ & $\begin{array}{c}\text { Treino de Mando com Dica de } \\
\text { Tato }\end{array}$ & $\begin{array}{c}\text { Treino de Mando com Dica } \\
\text { Imitativa }\end{array}$ \\
\hline $\begin{array}{c}\text { Estímulos } \\
\text { Antecedentes }\end{array}$ & $\begin{array}{c}\text { Itens da cadeia } \\
\text { comportamental, com } \\
\text { exceção de um item } \\
+ \\
\text { O que você quer? } \\
+ \\
\text { Dicas: apresentação do } \\
\text { estímulo discriminativo } \\
\text { (item) } \\
+ \\
\text { O que é isso? }\end{array}$ & $\begin{array}{c}\text { Itens da cadeia } \\
\text { comportamental, com } \\
\text { exceção de um item } \\
+ \\
\text { O que você quer? } \\
+ \\
\text { Dicas: } \\
\text { Faça isso!, emitido pelo } \\
\text { experimentador } \\
+ \\
\text { Apresentação da resposta } \\
\text { Modelo }\end{array}$ \\
\hline Respostas & \multicolumn{2}{|c|}{$\begin{array}{l}\text { Topografia de } \\
\text { resposta emitida } \\
\text { na linguagem de } \\
\text { sinais }\end{array}$} \\
\hline Consequentes & $\begin{array}{c}\text { Apres } \\
\text { Ficha } \\
\text { de } \\
\text { emi }\end{array}$ & $\begin{array}{l}\text { a do } \\
\text { caso } \\
\text { tas } \\
\text { om }\end{array}$ \\
\hline
\end{tabular}


O procedimento dos Testes de Generalização foi similar ao procedimento de Linha de Base e Treino a não ser pelos itens retirados que em algumas tentativas foram modificados. Por exemplo, o Participante 1 foi testado a emitir a topografia dinheiro, anteriormente treinada na cadeia de máquina de autovendas, diante uma máquina de auto-venda diferente daquela utilizada no treino. O Participante 2. que havia sido ensinado a emitir o mando água, durante a execução da cadeia comportamental de fazer sopa instantânea, o mesmo foi testado a emitir o mando para vasilha. Para uma explicação mais detalhada dos Testes de Generalização ver Anexo 1.

Em relação aos resultados, Hall e Sundberg (1987) descreveram que:

1. Apenas o Participante 2 pareceu ter adquirido o mando para água durante a Linha de Base.

2. O Treino de Mando com a manipulação das operações estabelecedoras foi efetivo para que os participantes emitissem as topografias pré-determinadas pelos autores, na condição de mando, antes da introdução das variáveis experimentais.

3. Não houve diferenças significativas na aquisição das topografias de mando entre os treinos com dica de tato e com dica imitativa.

4. Os Testes de Generalização apontaram que mandos foram emitidos a) diante diferentes condições de estímulos antecedentes; b) com topografias nunca anteriormente treinadas na contingência de mando; e c) nova topografias foram emitidas diante de estímulos completamente diferentes aos do treino.

Segundo Hall e Sundberg (1987), os resultados do estudo corroboram os achados do estudo de Lamarre e Holland (1985) da independência funcional entre os operantes verbais tato e mando. Assim, os autores apontaram que, para 
que uma mesma topografia treinada em tato apareça na condição de mando, há necessidade do treino direto em mando.

Os resultados obtidos nos Testes de Transferência de Função de tato para mando (Linha de Base) e nos Testes de Generalização, indicaram que "Para ambos os participantes, estes resultados indicam que a Independência Funcional estava presente quando os mandos foram inicialmente treinados, mas isso não foi mantido indefinidamente ${ }^{21 "}$ (Hall \& Sundberg, 1987, p.51).

Embora os resultados apresentados por Hall e Sundberg (1987) sejam similares aos resultados de Lamarre e Holland (1985) e de Twyman (1996), a interpretação dos dados obtidos pelos autores parece ser diferente. Enquanto Lamarre e Holland (1985) e Twyman (1996) parecem salientar a independência funcional dos operantes tato e mando e atribuem a variáveis da aprendizagem (história de aprendizagem dos operantes verbais sob controles múltiplos) a eventual emissão de respostas não diretamente treinadas em um dado operante, Hall e Sundberg parecem acreditar que a independência funcional entre os operantes tato e mando é mais transitória e aparece, especialmente, no momento da aquisição dos repertórios verbais Tato e Mando.

Outra pesquisa a ser discutida foi a desenvolvida por Ziomek e Rehfeldt (2008) que estudaram a independência funcional com respostas verbais em linguagem de sinais e $\operatorname{PECS}^{22}$ (Comunicação por Troca de Figuras) com os seguintes objetivos:

\footnotetext{
21 For both subjects, these results indicate that functional independence was present when mands were initially trained, but it was not maintained indefinitely.

22 O nome PECS é a abreviação de Picture Exchange Communication System, ou seja, é um Sistema de Comunicação por Troca de Figuras. Esse sistema foi desenvolvido por Frost e Bondy (1994) e teve como objetivo possibilitar uma alternativa à comunicação de crianças com desenvolvimento atípico que não desenvolveram a fala ou a desenvolveram de maneira muito rudimentar. Normalmente, indivíduos que se utilizam de tal sistema comunicativo entregam uma foto (disponível dentro de uma pasta ou álbum de fotos/figuras) para um ouvinte, produzindo, como conseqüência, um item reforçador (Mando). O PECS também
} 
1) Comparar o número de tentativas necessárias para que os participantes emitissem mandos com linguagem de sinais e com PECS;

2) Verificar a generalização (ou não) das topografias verbais adquiridas em mando com o uso do PECS em outros ambientes (diferentes do ambiente de treino) e com outras pessoas (não presentes durante o treino);

3) Verificar se, após o Treino de Mando com o PECS, os participantes emitiam as mesmas topografias verbais em tato e em intraverbal.

Foram participantes desse estudo três adultos com idade variando entre 41 anos e 52 anos, sendo um homem e duas mulheres. Todos os participantes apresentavam desenvolvimento atípico e deficiência mental.

Na Tabela 9 é apresentada, de maneira esquemática, a seqüência das etapas experimentais delineada por Ziomek e Rehfeldt (2008). Antes dos treinos e testes os autores identificaram dez itens possivelmente reforçadores, via entrevista e Teste de Preferência de Estímulos (DeLeon \& Iwata, 1996), para cada um dos participantes. Foram, então, conduzidos testes (mando, tato e intraverbal) e, na seqüência, foram ensinadas cinco topografias de mando com PECS e cinco topografias com linguagem de sinais concomitantemente. Por fim, foram conduzidos os Testes de Generalização e os Testes de Independência Funcional entre os operantes verbais.

possibilita que o indivíduo emita respostas verbais sob controle de outras relações entre estímulos, ou seja, como Tatos, Intraverbais ou outro operante verbal. 
TABELA 9

Seqüencia e Objetivos das Etapas Experimentais do Estudo de Ziomek e Rehfeldt (2008)

\section{TREINO DE MANDO DE ITENS PREFERIDOS}

(Participantes 1,2 e 3 )

Teste de Reforçadores: Identificação de dez itens possivelmente reforçadores.

Linha de Base: Teste da emissão de mandos antes da introdução das variáveis experimentais. Cinco topografias de mando foram testadas em PECS e outras cinco topografias de mando foram testadas em linguagem de sinais, em dois ambientes (de treino e de Teste de Generalização) e com dois experimentadores diferentes (um presente no treino e outro presente apenas em algumas tentativas da Linha de Base e no Teste de Generalização).

Testede Tato Testede Intraverbal: Teste da emissão das mesmas topografias verbais treinadas na condição de mando, nas condições de tato e intraverbal, antes da introdução das variáveis experimentais.

Treinos de Mando concomitantes: Treinou-se a emissão de mandos com o uso do PECS para cinco itens e em linguagem de sinais com outros cinco itens.

Teste de Generalização: Teste da emissão das topografias verbais que foram treinadas na condição de mando em outro ambiente (na cozinha do centro de atendimento) e com outro experimentador (adulto familiar aos participantes, mas não experimentador presente no Treino de Mando).

Teste de Tato Teste de Intraverbais: Teste da emissão das mesmas topografias verbais treinadas na condição de mando, nas condições de tato e intraverbal.

Treino de Mando sob controle de operações estabelecedoras condicionadas (OEC) (Participante 1)

Linha de Base: Três topografias de mando foram testadas em PECS e outras três topografias de mando foram testadas em linguagem de sinais, em dois ambientes (de treino e de teste de generalização) e com dois experimentadores diferentes (do treino e do teste de generalização).

\section{Testes de Tato e Intraverbal}

Treinos de Mando concomitantes

Teste de Generalização: teste da emissão das topografias verbais que foram treinadas na condição

de mando em outro ambiente (cozinha de sua residência) e com outro experimentador (adulto

familiar aos participantes, mas não experimentador das demais etapas do presente estudo). 
Foram propostas duas condições de testes e Treino de Mando. A primeira envolvia emitir mandos de itens reforçadores presentes e a segunda, que ocorreu apenas com o Participante 1, envolveu emitir mandos de itens ausentes, necessários para completar uma cadeia comportamental.

As tentativas de Linha de Base e Teste de Generalização eram iniciadas com a apresentação do item reforçador para o participante ou pela apresentação dos materiais necessários para a execução da cadeia comportamental com exceção de três itens ${ }^{23}$. O participante, por sua vez, deveria emitir a resposta de mando (com o uso do PECS ou em linguagem de sinais, este último apenas na condição de Linha de Base) em até cinco segundos da apresentação do item. Para a emissão das respostas com o uso do PECS os participantes tinham acesso a sua pasta de comunicação com as fotos dos cinco (ou três, no caso de respostas sob controle de operações reforçadoras condicionadas) itens preferidos e mais cinco (ou três) fotos de itens “distratores". Não havia conseqüências programadas para o responder do participante na Linha de Base e nos Testes de Generalização.

Os Testes de Tato envolviam a apresentação do estímulo discriminativo e a pergunta o que é isso? e o Teste do Intraverbal envolvia a apresentação de uma verbalização, emitida pelo experimentador. Antes dos Treinos de Mando, os Testes de Independência Funcional foram conduzidos em blocos de dez tentativas, duas tentativas para cada estímulo para ambas as modalidades de respostas (PECS ou linguagem de sinais). Não havia conseqüências programadas para o responder do participante nesses testes. Após o Treino de Mando, foram realizados dois blocos de dez tentativas de teste para cada item das respostas

${ }^{23}$ A cadeia comportamental utilizada no Treino de Mando com PECS foi fazer pudim instantâneo, sendo que os itens treinados em mando foram leite, jarra e vasilha. A cadeia comportamental utilizada no Treino de Mando em linguagem de sinais foi fazer chá instantâneo, sendo que os itens treinados em mando foram xicara, colber de pau e jarra. O Participante 1 já realizava as cadeias comportamentais antes de ser participante da presente pesquisa. 
apenas com PECS. No primeiro bloco de teste após o treino, não havia conseqüências programadas para o responder do participante. Já no segundo bloco de testes, o experimentador disponibilizava um reforço condicionado generalizado (elogio, por exemplo) quando o participante emitia a resposta correta.

Não havia, em nenhum dos testes descritos, disponibilização de dicas de respostas.

O Treino de Mando de itens reforçadores com o uso do PECS foi conduzido de maneira similar aos procedimentos propostos no manual de Frost e Bondy (1994). O procedimento de treino foi proposto em três fases.

$\mathrm{Na}$ primeira fase, o participante foi ensinado a pegar a foto do item presente, sendo que apenas esta foto estava presente na pasta de comunicação do participante e entregá-la para o experimentador. A tentativa de treino, nesta fase, era iniciada com a apresentação do item reforçador para o participante e, enquanto o participante tentasse pegar o item, o participante era ajudado a pegar a foto do item em sua pasta de comunicação e a entregá-la nas mãos do experimentador. O experimentador nomeava o item para o participante e, assim que a foto estivesse nas mãos do experimentador, o item reforçador era disponibilizado ao participante (itens comestíveis eram ingeridos e itens não comestíveis eram manipulados por até 15 segundos). A ajuda emitida pelo experimentador seguia uma hierarquia de dicas físicas, partindo de dicas mais intrusivas para dicas menos intrusivas. Para ser treinado na fase seguinte, o participante deve emitir mandos independentes, para os cinco itens, por dez tentativas consecutivas por item.

A segunda fase do Treino de Mando com PECS objetivou ensinar ao participante caminhar até sua pasta de comunicação, retirar a foto do item 
(apenas uma foto estava disponível na pasta) e entregá-la para o experimentador. A distância entre o participante e a pasta de comunicação, bem como a distância entre o participante e experimentador, foram gradualmente aumentadas. Para que o participante fosse treinado na terceira fase, o mesmo deveria emitir nove acertos (em blocos de dez tentativas) para cada um dos cinco itens treinados em PECS.

Por fim, a última fase do treino, teve por objetivo ensinar ao participante caminhar até sua pasta de comunicação (a $0,5 \mathrm{~m}$ de distância do mesmo), selecionar a foto do item diante de outras quatro fotos preferidas e cinco fotos de itens distratores. Os participantes foram inicialmente ensinados a diferenciar uma foto de um item reforçador de fotos de itens distratores: caso o participante pegasse uma das fotos dos itens distratores, o experimentador disponibilizava o item distrator, por outro lado, caso o participante selecionasse a foto do item reforçador, este era disponibilizado. Uma vez selecionada a foto, o experimentador verbalizava o nome do item e, com a foto em mãos, disponibilizava o item reforçador para o participante.

$\mathrm{Na}$ Tabela 10 apresentam-se os estímulos envolvidos nos treinos. Pelos dados da Tabela 10, percebe-se que o Treino de Mando de itens reforçadores, em ambas as modalidades de respostas, ocorreram sob controle de estímulos múltiplos. Neste, o estímulo discriminativo estava presente, constituindo um Treino de Mando-Tato.

O Treino de Mando de respostas em linguagem de sinais, parece ter ocorrido apenas sob controle das operações estabelecedoras, constituindo um Treino de Mando Puro. Já o mesmo treino com o uso do PECS, também ocorreu sob controle de estímulos discriminativos, mas, neste caso, com as fotos dos itens. 
TABELA 10

Estímulos Envolvidos nas Tentativas de Treino de Mando, na Pesquisa Conduzida por Ziomek e Rehfeldt (2008)

\begin{tabular}{|c|c|c|c|c|}
\hline \multicolumn{2}{|c|}{$\begin{array}{c}\text { Modalidade da } \\
\text { Resposta }\end{array}$} & Estímulos Antecedentes & Respostas & $\begin{array}{c}\text { Estímulos } \\
\text { Reforçadores }\end{array}$ \\
\hline PECS & $\begin{array}{l}\text { Itens sob } \\
\text { controle } \\
\text { de OEC }\end{array}$ & $\begin{array}{l}\text { Apresentação do item. } \\
\text { Pasta de comunicação com cinco } \\
\text { fotos de estímulos preferidos e cinco } \\
\text { fotos de estímulos distratores. } \\
\text { Dicas físicas } \\
\text { para a execução da Cadeia } \\
\text { comportamental, com exceção de três } \\
\text { Pasta de comunicação com três fotos } \\
\text { de estímulos preferidos e três fotos } \\
\text { de estímulos distratores. } \\
\text { Dicas físicas }\end{array}$ & $\begin{array}{l}\text { Selecionar a foto } \\
\text { correspondente ao } \\
\text { item reforçador e } \\
\text { entregá-la para o } \\
\text { experimenta-dor. }\end{array}$ & $\begin{array}{l}\text { Obtenção do item. } \\
\text { Nomeação vocal do } \\
\text { item por parte do } \\
\text { experimentador. }\end{array}$ \\
\hline SINAIS & $\begin{array}{c}\text { Itens } \\
\text { reforça- } \\
\text { dores } \\
\text { controle } \\
\text { de OEC }\end{array}$ & $\begin{array}{l}\text { Apresentação do Item. } \\
\text { Apresentação da resposta modelo por } \\
\text { parte do experimentador. } \\
\text { Dicas físicas. } \\
\text { para a execução da cadeia } \\
\text { comportamental, com exceção de três } \\
\text { itens. } \\
\text { Apresentação da resposta modelo por } \\
\text { parte do experimentador. } \\
\text { Dicas físicas }\end{array}$ & $\begin{array}{c}\text { Fazer o sinal do } \\
\text { item }\end{array}$ & $\begin{array}{l}\text { Obtenção do item. } \\
\text { Nomeação vocal do } \\
\text { item por parte do } \\
\text { experimentador. }\end{array}$ \\
\hline
\end{tabular}

Os resultados indicaram que nenhum dos participantes emitiu respostas corretas nos testes que antecederam à condição de treino. Além disso, todos os participantes aprenderam a emitir mandos com o uso do PECS. O Participante 1 adquiriu o mando do item presente após 340 tentativas de treino, enquanto o 
mando do item ausente foi adquirido de maneira consistente após 170 tentativas de treino. O Participante 2, que foi ensinado a emitir mando apenas com o item presente, adquiriu tal repertório após 150 tentativas de treino. O Participante 3, por sua vez, não adquiriu respostas em mando, nem com o uso do PECS, nem com linguagem de sinais. Este participante, durante o estudo, apresentou um quadro de demência precoce.

Os Participantes 1 e 2 não atingiram o critério de aprendizagem nos Treinos de Mando realizados com linguagem de sinais, ou seja, quando a topografia de mando foi adquirida com o uso do PECS, os participantes apresentaram menos de 50\% de acertos por dois blocos consecutivos, de dez tentativas cada.

Nos Testes de Generalização, realizados após os treinos, o Participante 1 emitiu $90 \%$ de acertos em mando de itens presentes e $85 \%$ de acertos em mandos de itens ausentes. O Participante 2, por sua vez, emitiu 90\% de acertos nestes testes.

Nos Testes de Independência Funcional, realizados ao final do estudo, o Participante 1 emitiu 90\% e 100\% de acertos, em cada bloco de testes, quando testado em tato (do item que estava presente no Treino de Mando). Em ambos blocos de Teste do Intraverbal, para o mesmo item, o Participante 1 emitiu 40\% de acertos nos dois blocos de testes. O Participante 2, por sua vez, emitiu 100\% de acertos em ambos blocos de Teste de Intraverbal. Os demais testes não apresentaram porcentagem de acertos significativas (menos de $10 \%$ ).

Ziomek e Rechfeld (2008) apontaram que o fato dos Participantes 1 e 2 terem atingido critério de aprendizagem nos Treinos de Mando com PECS não é suficiente para concluir que a comunicação com o uso do PECS é mais facilmente aprendido do que a comunicação com linguagem de sinais. Isso 
porque, nenhum dos participantes foi submetido a uma avaliação formal de prérequisitos (imitação de movimentos de coordenação motora fina, por exemplo), para verificar a possibilidade dos mesmos aprenderem a tarefa. Além disso, os procedimentos de ensino para topografias verbais em linguagem de sinais e com o uso do PECS eram distintos e incomparáveis.

Por fim, Ziomek e Rechfeld apontaram que a emissão de Tatos não diretamente treinados pelo Participante 1 e a emissão de intraverbais não diretamente treinados pelo Participante 2 com respostas verbais em PECS podem ser explicadas pelo fato de que o Treino de Mando com PECS foi realizado sob controle de estímulos múltiplos.

Outras pesquisas também estudaram a independência funcional entre os operantes tato e mando (Sigafoos, Doss \& Reichle, 1989; Sigafoos, Reichle, Doss Hall e Pettitt, 1990; Alves \& Ribeiro, 2007). Todas elas apresentam resultados similares aos resultados das pesquisas anteriores: no início do treino dos operantes verbais, as respostas de tato e mando apresentam-se funcionalmente independentes. No entanto, após uma história de treinos de respostas em tato e/ou mando, a mesma topografia passa a ser emitida sob controle de outros estímulos ou sob as condições do operante não diretamente treinado (pelo menos para aquela topografia).

Observa-se, entretanto, uma divergência na interpretação de tais dados entre os autores. Lamarre e Holland (1985), Hall e Sundberg (1987), Twyman (1996) e Ziomek e Rehfeldt (2008) parecem enfatizar o papel da história de aprendizagem de respostas verbais. Os demais autores parecem atribuir à transferência de funções/emergência entre os operantes tato e mando um papel ativo na emissão de novos repertórios verbais, a despeito dos múltiplos controles de estímulos presentes durante os treinos. 
Em relação aos estudos até então citados, concluímos que a independência funcional entre os operantes mando e tato foi identificada e apontada por todos os autores.

Por outro lado, foram apresentados dados nos quais uma determinada topografia foi ensinada na condição de tato (ou mando) e foi observada a emissão dessa mesma topografia na condição de mando (ou tato), nunca treinada diretamente.

Para entender esses dados, precisamos analisar as relações de controle estabelecidas por cada um dos autores nos treinos, a fim de identificar variáveis que possam ter determinado a emissão da topografia sob controle de outras relações entre estímulos. Sem dúvida, o tato e mando são repertórios independentes, mas temos que investigar que tipo de controle pode favorecer a emissão de uma resposta em uma condição nunca treinada diretamente.

$\mathrm{Na}$ Tabela 11 foram sistematizadas as variáveis de controle estabelecidas nos Treinos de Tato e Mando, em cada um dos estudos anteriormente descritos. A suposição aqui proposta é que tais variáveis podem ter facilitado a emissão de topografias de respostas nunca anteriormente treinadas em um dado operante. 
TABELA 11

Operantes Múltiplos Envolvidos nos Treinos de Mando e Tato nas Pesquisas de Lamarre e Holland (1985), Hall e Sundberg (1987), Twyman (1996) e Ziomek e Rehfeldt (2008)

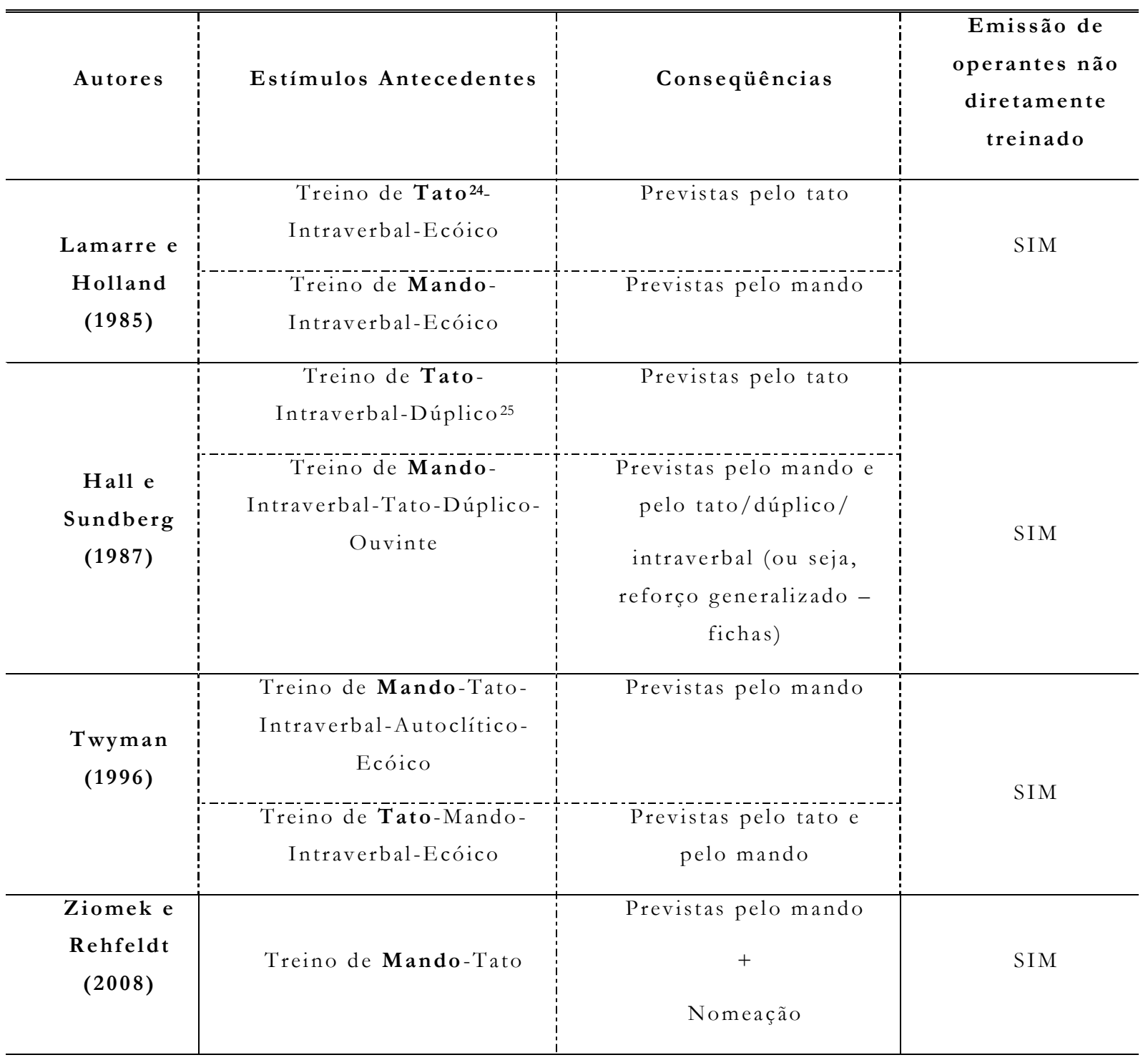

24 Os operantes em negrito foram os operantes que os autores objetivaram ensinar.

25 Michael (1982) ampliou a categorização do operante ecóico, proposta por Skinner (1957/1992), ao definir o operante duplico. O operante dúplico foi definido por Michael (1982) como sendo precedido por um antecedente verbal e a resposta tem uma correspondência formal com o estímulo controlador (p.3). Desta maneira, quando ocorre a imitação de respostas em linguagem de sinais, entende-se que ocorreu um comportamento dúplico. 
O presente estudo teve como objetivo estudar as relações entre tato e mando em respostas verbais baseadas na seleção de estímulos (fotos de itens). Para tanto, foram investigadas:

1) A independência funcional entre tatos e mandos de respostas verbais baseadas na seleção de estímulos. Como no Treino de Mando com PECS, descrito por Ziomek e Rehfeldt (2008), as respostas verbais baseadas na seleção de estímulos envolvem, necessariamente, a despeito do operante ensinado, respostas sob controle de estímulos discriminativos. Foi investigado, então, o papel dos estímulos discriminativos (fotos) na emissão das mesmas topografias de respostas no operante não diretamente treinado. Mais especificamente, se foi ensinado o tato com respostas verbais baseadas na seleção de estímulos, será que o estímulo discriminativo poderia exercer controle nas respostas de mando?

É plausível supor que, sendo os operantes verbais funcionalmente independentes, o treino de uma topografia verbal em uma dada condição (tato, por exemplo), não implicaria na emissão da mesma topografia verbal em uma outra condição (mando, por exemplo), sem o treino direto. No entanto, em se tratando de respostas emitidas sob controle de estímulos discriminativos comuns, além dos antecedentes específicos de cada um dos operantes tato e mando, poder-se-ia esperar que uma resposta treinada em tato, fosse emitida na condição de mando.

2) Caso o treino de tato de topografias de respostas baseadas na seleção de estímulos não fosse suficiente para produzir as mesmas topografias na condição de mando, quais variáveis poderiam ser acrescentadas aos treinos para que uma topografia treinada em tato possa ser emitida, sem treino direto, na condição de mando? E que variáveis poderiam ser acrescentadas ao treino de 
mando, além da apresentação do item estudada por Ziomek e Rehfeldt (2008), que poderiam produzir as mesmas topografias verbais na condição de Tato?

3) Por fim, este estudo buscou verificar o papel das respostas de nomeação, emitidas pelo experimentador, no treino de mando com respostas baseadas na seleção de estímulos, na emissão das mesmas topografias em tato e no desenvolvimento do repertório verbal do participante. 


\section{Método}

\section{Participantes}

Foram participantes da presente pesquisa cinco meninos: T1,com 4 anos de idade; T2,com 4 anos de idade; M1, com 7 anos de idade; M2, com 6 anos de idade; e M3, com 3 anos de idade ${ }^{26}$. Quatro destas crianças, que residiam na cidade de São Paulo, haviam sido diagnosticadas com autismo ${ }^{27}$ (T1, T2, M1 e M2), apresentando, assim, déficits importantes em três grandes áreas do desenvolvimento infantil: 1) linguagem; 2) interação social e 3) deficiências do comportamento (DSM-IV, 1994). O outro participante (M3), com 3 anos de idade, por sua vez, apresentava um atraso no desenvolvimento, principalmente no que diz respeito ao seu repertório verbal. Este participante residia na cidade de Campinas e não havia sido diagnosticado até a presente data.

Os cinco participantes foram selecionados em uma clínica particular, situada na capital, que atende crianças com desenvolvimento atípico na abordagem comportamental.

Todos os participantes freqüentavam escolas regulares da rede particular da cidade na qual residiam e estavam inseridos dentro do programa de inclusão da Educação Infantil.

Os participantes foram escolhidos de acordo com os seguintes critérios: 1) todos deveriam apresentar desenvolvimento atípico; 2) todos deveriam ter a disponibilidade de participar do estudo por, pelo menos, duas vezes na semana, 3) ter idade variando entre 3 e 7 anos.

26 A primeira letra da identificação do participante se refere ao ensino a que ele foi submetido: "T" para os participantes ensinados na condição de tato e "M" para os participantes ensinados na condição de mando. Os Treinos de Tato e Mando serão descritos adiante.

27 No Anexo 2 é apresentada uma descrição mais detalhada sobre o diagnóstico de autismo conforme o DSM-IV(1994). 
A participação de cada criança na pesquisa foi condicionada à autorização formal e por escrito de pelo menos um dos pais ou responsáveis, que assinaram um Termo de Consentimento Livre e Esclarecido (Anexo 3).

A caracterização dos participantes foi realizada a partir da Avaliação de Linguagem de Sundberg e Partington (1998), descrita e apresentada no Anexo 4.

$\mathrm{Na}$ Tabela 12 apresenta-se o currículo de treinamento realizado com cada um dos participantes, na terapia comportamental, na ocasião da coleta dos dados.

TABELA 12

Currículo Comportamental dos Participantes da Pesquisa na Ocasião da Coleta dos Dados

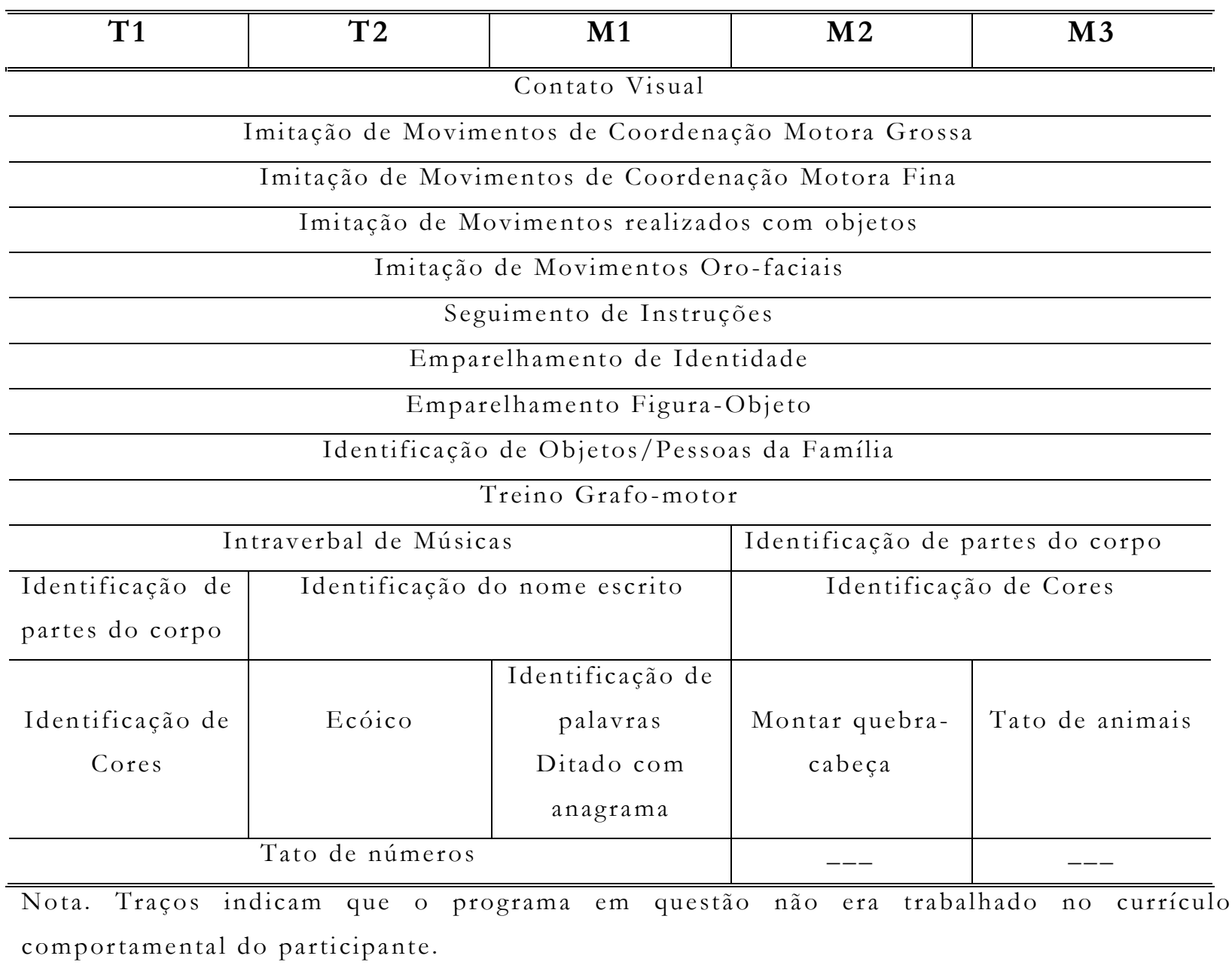




\section{Ambiente Experimental}

Tanto as sessões experimentais de T1 quanto de M3 ocorreram em suas próprias residências, na sala de televisão da casa, local em que comumente se aplicava a terapia comportamental, semanalmente, com ambas as crianças. Nesta sala havia uma mesa pequena com duas cadeiras, televisão e aparelho de DVD, apoiados num aparador. Atrás da mesa e das cadeiras havia um sofá, em ambas as residências. As salas mediam, aproximadamente, $5 \mathrm{~m} X 4 \mathrm{~m}$. Os materiais utilizados nas sessões de terapia comportamental (estímulos reforçadores, itens da cadeia comportamental, folhas de registros, caneta etc) ficavam armazenados dentro de caixas dispostas ao lado da mesa, onde experimentador e o participante se sentavam. As caixas ficavam fechadas durante toda a sessão experimental; ficavam ao alcance do participante apenas os materiais necessários para a presente coleta de dados (por exemplo, objetos da cadeia comportamental e folhas de registro).

As demais sessões experimentais, das quais os participantes T2, M1 e M2 participaram, ocorreram na clínica particular onde os mesmos eram atendidos, semanalmente, em duas salas distintas. T2 e M2 foram atendidos na mesma sala, do andar superior da clínica. Nesta sala encontrava-se uma mesa pequena com duas ou três cadeiras e, acima do alcance das crianças, encontravam-se duas prateleiras, nas quais estavam apoiados brinquedos (carrinhos, bonecas, casinhas, livros, giz, televisão e aparelho de disco digital de vídeo [DVD], etc.). Nesta sala havia ainda um sofá. A sala de coleta freqüentada pelo participante M1 era do mesmo tamanho que a citada anteriormente, também localizada no andar superior da clínica e apresentava uma mesa de tamanho médio, com duas ou três cadeiras. Nela, existia uma estante na qual ficavam apoiadas uma 
televisão e um aparelho de DVD. Os brinquedos e outros materiais ficavam guardados dentro da estante, fechados, estando, portanto, fora do alcance e do campo visual da criança.

\section{Sessões experimentais}

Cada sessão experimental durava, aproximadamente, dez minutos. Foram conduzidas de uma a dez sessões experimentais por dia de coleta. A coleta ocorreu de uma a três vezes na semana. Eram coletados dados durantes os dez minutos de sessão; a quantidade de dados coletados dependia de variáveis motivacionais do participante. Por exemplo, se o participante apresentasse um comportamento de birra, durante a sessão, menos dados eram coletados, pois a sessão experimental era encerrada e procedimentos terapêuticos eram iniciados (por exemplo, diminuição da demanda de trabalho, introduzindo uma tarefa mais simples para o participante, reforçamento de outros comportamentos, etc.). Por outro lado, se o participante apresentava-se colaborador, mais dados eram coletados.

Foram experimentadores dessa pesquisa quatro profissionais que atuam com crianças com desenvolvimento atípico. A coleta de dados sempre foi realizada em duplas de profissionais, com exceção do participante M3, que teve seus dados coletados apenas com a autora da pesquisa. As sessões experimentais (incluindo as sessões nas quais a autora estava presente) eram analisadas semanalmente, a partir do relato dos experimentadores, dos dados do registro e das imagens filmadas.

\section{Material}

- Câmera fotográfica e filmadora digital Canon Power Shot A95. 
- Termo de Consentimento Livre e Esclarecido (Anexo 3).

- Protocolo de Avaliação de Linguagem desenvolvido por Sundberg e Partington (1998) (Anexo 5).

- Itens (comidas ou brinquedos) que, segundo dados do Teste de Preferência de Estímulos, funcionam como estímulos reforçadores para os participantes.

- Folha de registro do Teste de Preferência de Estímulos (Anexo 6).

- Itens (utensílios, brinquedos, objetos) necessários para a execução da cadeia comportamental.

- Folha de registro da cadeia comportamental (Anexo 7).

- Fotos de itens, ampliadas no tamanho $10 \mathrm{~cm} \mathrm{X} 15 \mathrm{~cm}$.

- Folha para registro das respostas (tato e mando) emitidas pelos participantes (Anexo 8).

\section{Procedimento Geral}

Os seguintes cuidados foram tomados pela autora desta pesquisa no responder ao protocolo de Avaliação de Linguagem (Sundberg \& Partington, 1998): (a) Foram analisados os dados da intervenção comportamental de cada uma das crianças, procurando identificar os comportamentos-alvos que estavam sendo trabalhados na ocasião, bem como foram identificados os comportamentos já desenvolvidos no repertório comportamental de cada um dos participantes; (b) Cada um dos participantes foram observados por duas horas (duas sessões de uma hora cada, em dias alternados), durante as sessões de terapia comportamental, em que outros terapeutas estavam atuando. Nessas duas horas, os comportamentos descritos no protocolo de linguagem de cada participante da pesquisa puderam ser observados diretamente. 3) Por fim, foi realizada uma reunião com o profissional (terapeuta comportamental) que atuava com a criança 
na clínica em questão para responder ao protocolo. Essa reunião teve como objetivo verificar se ambas, experimentadora e terapeuta, respondiam ao formulário da mesma maneira, garantindo a consistência dos dados.

A Avaliação de Linguagem proposta por Sundberg e Partington (1998) foi aplicada com o objetivo de investigar que aspectos do repertório verbal do participante apresentavam-se menos desenvolvidos (ou em uma menor freqüência) e quais se apresentavam mais fortalecidos (ou em uma maior freqüência).

A mesma avaliação contemplou a identificação e quantificação de 12 classes comportamentais relacionadas ao repertório verbal do participante, categorizadas em cinco níveis de complexidade (nível 1 - ou escore 1 - descreve um comportamento verbal menos complexo e nível 5 - ou escore 5 - descreve um nível de repertório verbal mais complexo).

No Anexo 4, pode ser visualizado a descrição resumida dos critérios de atribuição de escores empregados no instrumento de Avaliação de Linguagem de Sundberg e Partington (1998).

\section{Delineamento Experimental}

Foi utilizado o delineamento de Pré-Teste, Treino e Pós-Teste: aplicou-se primeiramente um Pré-Teste e foi introduzida, em seguida, a variável experimental (Treino de Tato ou de Mando) e, seguiu-se, por fim, o Pós-Teste.

Com os participantes T1 e T2 foi realizado o Treino de Tato e com os participantes M1, M2 e M3 foi realizado o Treino de Mando. As respostas de mando e tato eram sempre testadas e treinadas aos pares, sendo que, para os participantes T1 e M3, treinou-se um par de estímulos por vez. 
TABELA 13

Delineamento Experimental Geral

\begin{tabular}{|c|c|}
\hline Participantes T1 e T2 & Participantes M1, M2 e M3 \\
\hline \multicolumn{2}{|c|}{ Teste de Preferência de Estímulos } \\
\hline \multicolumn{2}{|c|}{ Treino de cadeia comportamental } \\
\hline \multicolumn{2}{|c|}{ Pré-Teste de Mando e Tato (dois itens) } \\
\hline Treino de Tato (dois itens) & Treino de Mando (dois itens) \\
\hline
\end{tabular}

Variáveis Experimentais e Variáveis de Observação (Matos, 1990)

Todos os participantes foram expostos a uma condição experimental na qual se ensinava uma relação verbal (ou de tato ou de mando) e testava-se outra relação verbal (se fora ensinado a relação de tato, testava-se mando e viceversa), que não fora explicitamente ensinada pelo experimentador.

Neste estudo, define-se mando como uma classe de respostas que envolve uma operação estabelecedora condicionada, a resposta de seleção de uma foto e uma conseqüência reforçadora específica (obtenção do objeto da foto).

O tato, por sua vez, foi aqui definido por uma classe de respostas que envolve a apresentação de um item (estímulo visual), a resposta de seleção de uma foto (do item) e uma conseqüência reforçadora generalizada, que seria um elogio.

Os participantes M1, M2 e M3 foram ensinados a emitir mandos por determinados itens e foram testados, na emissão das mesmas topografias verbais, na condição de tato. Os participantes T1 e T2 foram ensinados a emitir tatos e testados, na emissão das mesmas topografias verbais, na condição planejada de contingências de mando. 
Observou-se, nos testes, se ocorria ou não a emissão do repertório não diretamente ensinado (se o ensino realizado com o participante era de mando, verificava-se a emissão da mesma topografia em tato e se o ensino realizado com o participante era de tato, verificava-se a emissão da mesma topografia em mando).

$\mathrm{Na}$ Tabela 14 é apresentado, de maneira esquemática, as classes de respostas envolvidas no estudo.

TABELA 14

Definição das Classes de Respostas Verbais

\begin{tabular}{|c|c|c|c|c|}
\hline \multirow[t]{2}{*}{$\begin{array}{c}\text { Operantes } \\
\text { Verbais }\end{array}$} & \multirow[t]{2}{*}{$\begin{array}{c}\text { Estímulos } \\
\text { Antecedentes }\end{array}$} & \multirow[t]{2}{*}{ Resposta do participante } & \multicolumn{2}{|c|}{$\begin{array}{c}\text { Estímulos } \\
\text { conseqüentes }\end{array}$} \\
\hline & & & $\begin{array}{l}\text { LBou } \\
\text { Teste }\end{array}$ & Treino \\
\hline Tato & $\begin{array}{c}\text { Apresentação de um } \\
\text { objeto/item } \\
\text { Presença do } \\
\text { experimentador. }\end{array}$ & $\begin{array}{l}\text { Selecionar, dentre } 2 \text { fotos } \\
\text { e um cartão em branco, a } \\
\text { foto correspondente ao } \\
\text { item apresentado (ou item } \\
\text { presente) }\end{array}$ & ---- & Elogio \\
\hline Mando & $\begin{array}{l}\text { Apresentação dos } \\
\text { itens necessários } \\
\text { para execução da } \\
\text { Cadeia } \\
\text { comportamental, } \\
\text { com exceção de um } \\
\text { item; } \\
\text { Presença do } \\
\text { experimentador. }\end{array}$ & $\begin{array}{l}\text { Selecionar, dentre } 2 \text { fotos } \\
\text { e um cartão em branco, a } \\
\text { foto correspondente ao } \\
\text { item ausente, necessário } \\
\text { para completar a cadeia } \\
\text { comportamental. }\end{array}$ & ---- & $\begin{array}{c}\text { Receber o } \\
\text { item/ } \\
\text { Objeto }\end{array}$ \\
\hline
\end{tabular}

Nota. Traços indicam que não eram disponibilizadas consequências reforçadoras nas condições experimentais em questão. 
Procedimentos prévios ao Treino dos Operantes Verbais e Treino de Pré-Requisitos - Teste de Preferência de Estímulos (De Leon \& Iwata, 1996) e Treino de Cadeias Comportamentais (Hall \& Sundberg, 1987).

1. Teste de Preferência de Estimulos (De Leon e Iwata, 1996)

Foram realizados, com cada um dos participantes, de um a quatro Testes de Preferência de Estímulos, conforme proposto por DeLeon e Iwata (1996) com estímulos múltiplos, sem reposição. Para cada testagem, o experimentador selecionou sete itens que, segundo observação prévia dos participantes, pareciam ser brinquedos/atividades "preferidos" pelos mesmos. Os sete itens eram disponibilizados um ao lado do outro, sobre a mesa, numa distância de $10 \mathrm{~cm}$ entre cada estímulo. A ordem de apresentação dos estímulos era aleatória. O experimentador dava a instrução pegue um ao participante e este, por sua vez, deveria pegar com suas mãos um dos estímulos apresentados. A resposta de pegar o objeto ou item foi definida por qualquer aproximação física em sua direção ao item (pegar com as mãos, tocar com os dedos, comer, etc.).

Após pegar o primeiro item (primeira tentativa de escolha), a criança podia manipular o objeto (no caso, brinquedo/atividade) por até 30 segundos e este era, então, retirado do acesso à criança. Os itens, uma vez escolhidos pelos participantes, não foram repostos na mesa para as tentativas seguintes. Assim, a cada tentativa de escolha havia um item a menos à mesa.

Nota-se que a ordem dos estímulos, a cada tentativa de escolha, foi modificada. Para tanto, o experimentador movia o item da esquerda da linha para a direita (primeiro item da linha). Este procedimento prosseguia até o participante não escolher nenhum dos itens em 30 segundos desde o começo da tentativa, ou até todos serem escolhidos. 
O primeiro item escolhido pelo participante foi considerado o preferido (possivelmente reforçador), o segundo foi seu segundo preferido e assim por diante. Todas as respostas foram registradas em folha de registro, apresentadas em anexo (Anexo 6).

Os dois itens preferidos eram utilizados nas sessões experimentais subseqüentes, para cada participante, durante o ensino de cadeia comportamental.

\section{Treino de Cadeias Comportamentais (Hall \& Sundberg, 1987)}

A cada participante foi ensinado completar de duas a oito cadeias comportamentais, envolvendo os brinquedos ou atividades possivelmente reforçadoras (pelo menos identificado como tal no teste de preferências de estímulos ${ }^{28}$, adaptando o procedimento utilizado por Hall e colaboradores (1987). O objetivo do ensino de cadeias foi arranjar contingências específicas de controle de operações estabelecedoras para os testes e ensinos de Mando que foram aplicados em um segundo momento.

Uma vez identificado o brinquedo/atividade preferida pela criança (Teste de Preferências de Estímulos), o experimentador desenvolvia uma cadeia comportamental para a manipulação apropriada do objeto ou da atividade preferida ${ }^{29}$. Assim, o experimentador fragmentou a cadeia (do brincar ou da atividade) em pequenos passos ou tarefas (análise de tarefas). Por exemplo, se o participante escolhesse, no Teste de Preferência de Estímulos, um caminhão, o experimentador planejava uma cadeia de brincar, na qual o participante deveria

\footnotetext{
28 Nota-se que para cada participante foram ensinadas diferentes cadeias comportamentais, determinadas pelo Teste de Preferência de Estímulos.

29 A Cadeia Comportamental desenvolvida para o participante foi elaborada a partir do conhecimento prévio das brincadeiras e atividades familiares a cada um dos participantes, envolvendo tais brinquedos/atividades.
} 
fazer com que o caminhão descesse uma rampa. Sempre a primeira tarefa, de todas as cadeias desenvolvidas e ensinadas, foi tocar com as mãos o brinquedo/atividade (possível indicativo de que as operações estabelecedoras estavam controlando o responder do participante). A segunda tarefa, nesse exemplo, seria pegar o caminhão; a terceira, levar o caminhão à rampa; a quarta, posicionar o caminhão de modo que ele pudesse descer e por fim, a quinta tarefa, soltar o caminhão na rampa.

As cadeias comportamentais foram planejadas e analisadas/fragmentadas em tarefas simples e passíveis de serem executadas (às vezes com alguma ajuda do experimentador) pelos participantes. No entanto, como as tarefas deveriam envolver os estímulos de preferência do participante (e não estímulos escolhidos pelo experimentador), no planejamento das cadeias nem sempre foi possível equalizar o nível de dificuldade entre as mesmas.

Para que o participante fosse ensinado a executar a cadeia comportamental, o experimentador dispunha todos os materiais ou equipamentos necessários para a execução da mesma e oferecia dicas físicas (ajudar pegando nas mãos do participante, ajudar apontando para os materiais necessários, ajudar dando um toque no cotovelo do participante, etc.) para o participante realizar cada uma das tarefas da cadeia comportamental. Não ocorreu qualquer tipo de instrução vocal (vocalizações como pegue isso, abra mais forte, etc.), já que no treino de cadeias comportamentais “...uma resposta comumente leva o estímulo à outra ${ }^{30} . "(K e l l e r \&$ Schoenfeld, 1950/1995, p.197), sem que seja necessário que o participante emita o comportamento de seguir instruções provindas do experimentador.

30 “... one response commonly produces the stimulus for another." 
As dicas físicas para a execução da cadeia foram apresentadas numa hierarquia, iniciando-se com uma dica mais intrusiva (o experimentador executava todos os movimentos junto com o participante, levando a mão do mesmo para a execução da tarefa), a uma menos intrusiva (apontar para os objetos necessários para execução da cadeia, por exemplo), até promover a independência na execução da tarefa (participante realizar a tarefa sem qualquer tipo de ajuda). O ensino da cadeia comportamental ocorreu até o participante realizar a primeira tarefa da cadeia comportamental de maneira independente, por três vezes consecutivas.

Não foi exigido que o participante realizasse todos os passos da cadeia comportamental de maneira independente, pois este poderia ser um critério muito difícil a ser atingido, mas apenas que a primeira tarefa da cadeia fosse realizada de maneira independente.

As respostas foram registradas em folhas de registros apropriadas (Anexo 7).

O objetivo do treino de cadeia foi preparar os participantes para os procedimentos de Treino e Testes de Mando, que serão descritos adiante.

Treinos e Testes de Mando e Tato

1. Especificidades dos Treinos e Testes de Tato e Mando ${ }^{31}$.

1.a. Treino e Testes de Mando - Procedimento de Interrupção de Cadeia (Hall \& Sundberg, 1987)

\footnotetext{
${ }^{31}$ Neste momento do texto, apenas descrições gerais dos testes e treinos são abordadas. As sequências exatas de cada teste e treino, bem como as especificações de cada contingência envolvida, seja no treino, seja no teste, serão apresentadas nos Estudos 1, 2 e 3, descritos adiante.
} 
Antes de iniciar uma tentativa de Treino/Teste de Mando, o experimentador esperava que o participante sentasse à mesa de atividades e chamava o participante pelo seu nome. Iniciava-se, então, a tentativa de Treino ou Teste de Mando.

Cada tentativa era iniciada com a apresentação dos itens necessários para a execução da cadeia comportamental (brinquedos/atividades) à mesa de trabalho (operação estabelecedora condicionada), com exceção de um item. Além disso, eram apresentados sobre a mesa, três estímulos visuais (duas fotos e um cartão em branco), dispostos lado a lado, que eram os estímulos de seleção. Na Figura 1 pode ser observada a disponibilização dos materiais à mesa, no início de uma tentativa de Treino/Teste de Mando.

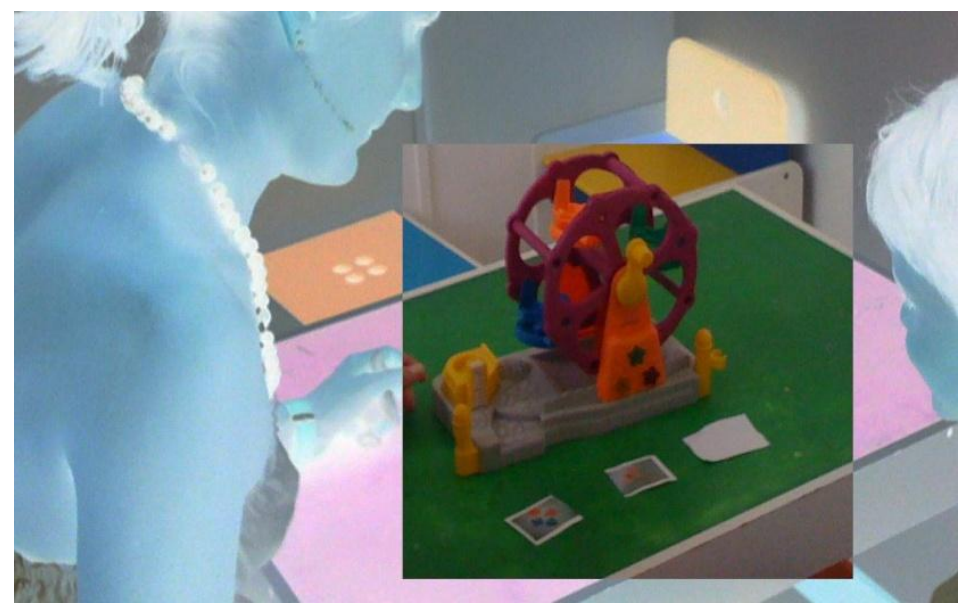

Figura 1. Ilustração da disponibilização dos materiais à mesa, no início de uma tentativa de Treino/Teste de Mando.

Uma vez iniciada a execução da cadeia comportamental, o participante poderia (ou não) emitir a resposta de pegar a foto correspondente ao item ausente dentre outros dois estímulos (a foto do segundo item do par de estímulos e um cartão em branco), em até dez segundos e entregá-la para o experimentador. 
Nas tentativas de treino, a conseqüência prevista para o responder correto (pedir o item com o uso da foto) foi o recebimento do item ausente. Com o item em mãos, o participante poderia finalizar a execução da cadeia comportamental. Ocorria, então, o intervalo entre tentativas (ITI) de 5 segundos.

Nas tentativas de teste, não havia conseqüências programadas para o responder dos participante: os itens apresentados no início de cada tentativa permaneciam à mesa (por até dez segundos) e o item ausente não era apresentado para o participante. Passado esse período, todos os materiais eram retirados da mesa e ocorria o ITI.

\section{1.b. Treinos e Testes de Tato - Procedimento de Escolha de Acordo com o}

\section{Modelo}

Quando o participante estivesse sentado à mesa e com contato visual estabelecido, o experimentador iniciava uma tentativa de tato apresentando de um estímulo visual (objeto/item), que ficava nas mãos do experimentador e três estímulos visuais (a foto do item a ser tateado, a foto do segundo item do par de estímulos em treinamento e um cartão em branco) dispostos lado a lado à mesa de atividades. Na Figura 2 apresenta-se uma ilustração de uma tentativa de tato.

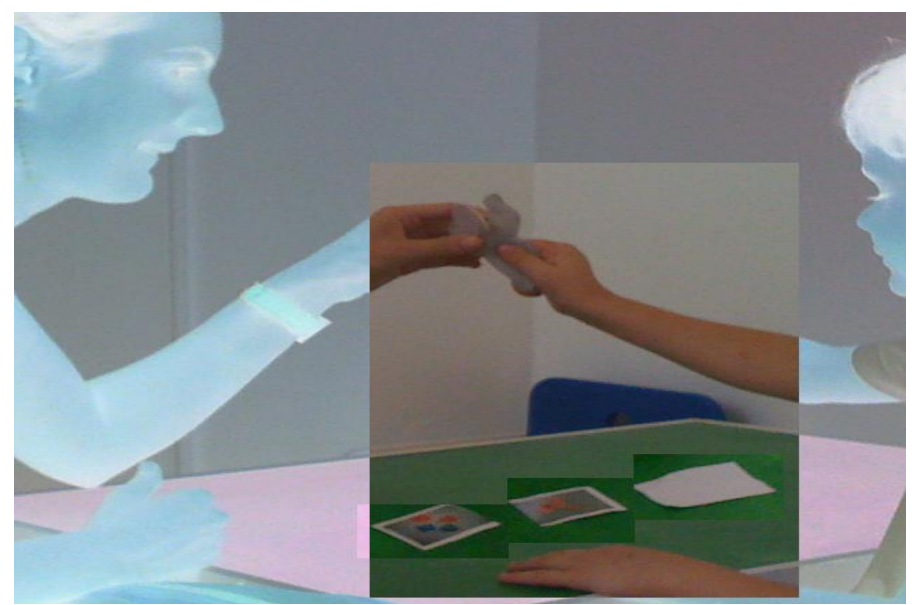

Figura 2. Ilustração da disponibilização dos materiais à mesa, no início de uma tentativa de Treino/Teste de Tato. 
Frente aos estímulos antecedentes, o participante deveria emitir a resposta de pegar a foto correspondente ao item apresentado em até 10 segundos e entregá-la para o experimentador.

A conseqüência reforçadora programada para o responder correto, nas tentativas de treino, era o elogio dado pelo experimentador. Nas tentativas de testes, não havia conseqüências programadas para o responder do participante, como nos Testes de Mando.

\section{Procedimentos comuns nos Treinos e Testes de Tato e Mando}

Antes dos treinos, os participantes eram expostos à condição de Pré-Teste, na qual quatro tentativas de cada relação verbal eram testadas para cada item. Nos testes, após o ITI, o experimentador solicitava ao participante a execução de uma demanda simples (por exemplo, pedia que o participante mandasse um beijo), para que outro comportamento do participante fosse reforçado com elogios e carinho (reforço generalizado). Para a coleta dos dados do Pré-Teste realizou-se duas sessões experimentais com cada um dos participantes.

O treino era conduzido se o participante não emitisse as respostas de mando e nem de tato nas tentativas de Pré-Teste, ou seja, se o participante não selecionasse a foto do item ausente (no caso do mando) e se ele não selecionasse a foto do item apresentado (no caso do tato).

As tentativas de treino ocorreram com os dois itens concomitantemente, ou seja, ora se apresentava uma tentativa com o Item 1, ora se apresentava uma tentativa com o Item 2 e, assim, sucessivamente. A seqüência da apresentação das tentativas com o item 1 e com o item 2 era randômica para que o participante não respondesse sob controle de uma seqüência de respostas previamente estabelecida. Além disso, a ordenação espacial (esquerda, centro e 
direita) da apresentação dos estímulos visuais de seleção dispostos à mesa, também era randômica, de modo a impossibilitar que o participante fosse controlado pela posição dos estímulos de seleção. A seqüência dos estímulos a serem treinados e sua ordenação dos estímulos eram previamente estabelecidos e discriminados na folha de registro (Anexo 8).

Para maximizar as chances de acerto das respostas dos participantes durante o procedimento de treino, o experimentador disponibilizava dicas de respostas (apontava para as fotos que os participantes deveriam pegar e entregar ou levava a mão do participante para a foto a ser escolhida). As dicas eram gradualmente retiradas à medida que o participante emitia a resposta de maneira independente.

Foi considerado um erro quando o participante selecionava a foto do item não referente àquele ausente na cadeia ou quando o participante se levantava da mesa de atividades ou fazia outra coisa, tal como comportamentos estereotipados (característicos do quadro diagnóstico de autismo). No primeiro caso de erro, seguia-se o procedimento de correção e no segundo caso, finalizava-se a apresentação da tentativa de ensino.

O procedimento de correção consistia em pegar na mão do participante e direcioná-la para a foto correspondente ao item em questão.

Acertos com dicas foram registrados como $(+d)$ e acertos sem dicas foram registrados como (+) e erros foram registrados como (-).

O treino era encerrado quando o participante atingia pelo menos três acertos consecutivos (em um bloco de oito tentativas), com cada um dos itens ensinados (critério de aprendizagem do ensino), sem dicas de respostas. 
Uma vez atingido o critério de aprendizagem do operante treinado, os participantes eram expostos a uma nova condição de teste. O procedimento do Pós-Teste foi exatamente o mesmo do Pré-Teste.

O objetivo do Pós-Teste foi de verificar se a relação verbal treinada pelo experimentador, com dois itens específicos, favoreceria o aparecimento de uma relação não explicitamente treinada com os mesmos itens. Era de se esperar que, uma vez que os operantes verbais são funcionalmente independentes, o treino de duas topografias verbais em uma dada condição, não implicaria na emissão da mesma topografia verbal em uma outra condição. No entanto, em se tratando de respostas emitidas sob controle de estímulos discriminativos comuns (fotos dos itens), poderia se esperar que uma resposta treinada em mando fosse emitida em tato e vice-versa.

Um segundo par de itens era introduzido e ensinado, caso o participante não emitisse as respostas verbais do operante no Pós-Teste do primeiro par. Foram treinados e testados de um a quatro pares de itens com os participantes do estudo.

\section{Validação por Consenso das Respostas emitidas pelos participantes e do Procedimento}

As sessões experimentais foram conduzidas por quatro profissionais: dois experimentadores principais e dois experimentadores coadjuvantes. A cada sessão experimental estavam presentes um experimentador principal e um experimentador coadjuvante. Os experimentadores principais (sendo um deles, a autora da presente pesquisa) executavam e registravam os procedimentos descritos desta pesquisa. Os experimentadores coadjuvantes filmavam (quando fosse o caso) e observavam as sessões experimentais. Apenas as sessões realizadas com o participante $\mathrm{M} 3$ foram conduzidas sem a presença de um 
experimentador coadjuvante. No entanto, as imagens foram observadas e analisadas pela equipe de profissionais da mesma maneira que as demais sessões filmadas.

Foram filmadas e analisadas $50 \%$ das sessões experimentais. Semanalmente cada filmagem era observada, analisada e registrada pela equipe de experimentadores. Nesse encontro era feito a fidedignidade dos registros realizados pelo experimentador principal.

Pelas filmagens pôde-se avaliar que:

1. As respostas emitidas pelos participantes foram emitidas tal e qual as registradas pelo experimentador, com concordância de $100 \%$.

2. O procedimento realizado pelo experimentador realizado foi fiel ao procedimento descrito em $95 \%$ das sessões filmadas.

A análise acima apresentada revela que o procedimento foi fidedigno ao descrito na sessão de método. 


\section{Estudo 1}

O Estudo 1 teve como objetivo verificar se topografias de respostas baseadas na seleção de estímulos, treinadas na condição de tato, seriam emitidas na condição de mando, sem treino direto. Para tanto, o participante foi ensinado a emitir cinco respostas em tato e testado, nas mesmas topografias, em mando.

\section{Método}

\section{Participante}

Foi participante deste estudo T1. Na Figura 3 são apresentados os escores obtidos pelo participante T1, por ocasião da coleta de dados, na Avaliação de Linguagem (Sundberg \& Partington, 1998). Comparando as diferentes habilidades de T1, observa-se que o mesmo apresentava um repertório mais desenvolvido em relação ao pareamento de estímulos visuais, seguido da imitação de movimentos de coordenação motora. Ambos os repertórios envolvem o responder sob controle de estímulos visuais. Nas demais habilidades, relacionadas ao responder sob controle de estímulos auditivos, T1 apresentava repertório mais deficitário. A interação social, por sua vez, provavelmente produto de tais dificuldades, era a habilidade menos desenvolvida. 


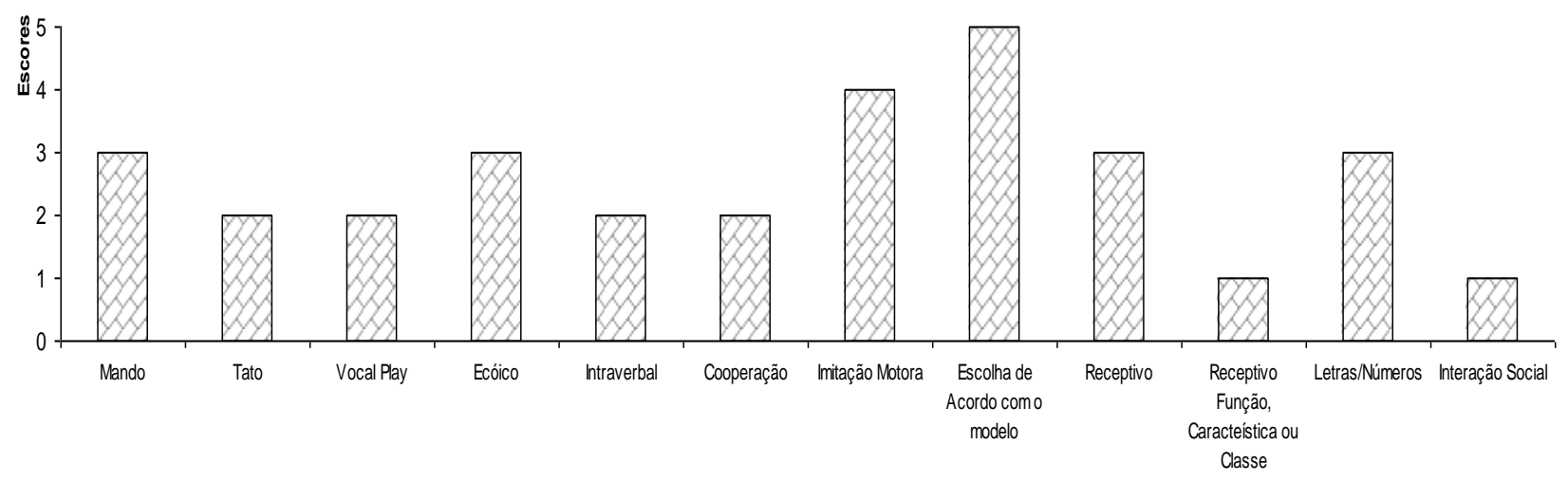

Figura 3. Escores obtidos por T1 na Avaliação de Linguagem de Sundberg e Partington (1998).

Na Tabela 15 destaca-se os estímulos visuais e auditivos para os quais T1 respondia com mais facilidade. Nota-se que T1 pareava, por exemplo, figuras/fotos de crianças entre si e adultos entre si. No entanto, quando questionado se uma determinada pessoa era uma criança ou um adulto, o mesmo não era capaz de nomear adulto ou criança, nem mesmo apontar para o adulto ou para criança, diante de uma instrução auditiva aponte para o adulto ou aponte para a criança.

Procedimentos Prévios e Treino de Pré-requisitos - Teste de Preferência de Estímulos (De Leon \& Iwata, 1996) e Treino de Cadeias Comportamentais (Hall \& Sundberg, 1987)

Foram realizados com T1 quatro Testes de Preferência de Estímulos e foi ensinado a T1 a completar oito cadeias comportamentais. Na Tabela 16 são apresentados os dois primeiros itens escolhidos em cada um dos testes de preferência de estímulos, bem como cada cadeia desenvolvida e ensinada para o participante. 
TABELA 15

Descrição do Repertório Comportamental de T1

Mando: Apontava para objetos que desejava, em algumas ocasiões verbalizava a palavra $/ d a /$, concomitante ao apontar. Seu livro de comunicação (PECS) tinha as figuras de banheiro, intervalo, chocolate e coca-cola, que eram utilizadas apenas com ajuda do terapeuta.

Tato: Diante de figuras/fotos ou miniaturas de leão, vaca e abelha, T1 emitia suas respectivas onomatopéias. Além disso, diante de sua mãe, emitia a verbalização $/ m a /$.

Vocal Play: Emitia o som de sílabas terminadas em $/ a /,|d a /| m, a /, \mid t a /$ em alguns momentos em que estava sozinho.

Ecóico: Repetia sílabas simples da língua portuguesa (/da/, /mel e onomatopéias).

Intraverbal: Quando lhe era perguntado seu nome, qual era sua escola e quantos anos tinha, T1 verbalizava a primeira sílaba de seu apelido, a primeira sílaba do nome de sua escola e /qual (referente a sua idade quatro).

Cooperação com adultos: Emitia uma resposta fácil e curta (imitava um bater palmas, em um procedimento de tentativa discreta ${ }^{32}$, por exemplo) quando disponível um item com alto valor reforçador.

Imitação Motora: Imitava movimentos de coordenação motora fina e grossa (abrir e fechar as mãos, levantar os braços, bater palmas e fazer tchau).

Escolha de acordo com o modelo: Emparelhava cores iguais entre si (amarelo, vermelho, verde e azul); as formas triângulo, círculo e quadrado; emparelhava as vogais A, E, I, O; os números 1, 2 e 3; figuras iguais de alguns personagens e animais. Categorizava, ainda, fotos de bebidas de fotos de comidas; separava fotos de animais de fotos de pessoas; separava objetos de adultos de objetos de crianças.

Repertório Receptivo: Seguia as instruçóes simples aponte, mande um beijo, sente, máos no colo e toque aqui.

Repertório Receptivo por função, característica ou classe: Não apontava para figuras ou objetos diante de estímulos auditivos do nome de tal categoria.

Letras e números: Identificava os números de um a cinco; nomeava os números 1,2 e 3 e identificava as vogais.

Interação social: Não iniciava qualquer interação social com seus pares ou adultos.

Nota: Repertório comportamental classificado de acordo com a Avaliação de Linguagem de Sundberg e Partington (1998).

32 Tentativa Discreta é o nome dado a um procedimento de ensino que envolve quatro passos sucessivos: a) instrução, b) resposta da criança, c) consequenciação (reforço positivo) e d) intervalo entre tentativas (Catania, 1999, p. 424). 
TABELA 16

Itens Preferidos pelo Participante T1 no Teste de Preferência de Estímulos (De

Leon \& Iwata, 1996) e Cadeias Comportamentais Desenvolvidas e Ensinadas para T1

\begin{tabular}{|c|c|}
\hline Itens Preferidos & Cadeias Ensinadas \\
\hline 1. Alfabeto Sonoro & 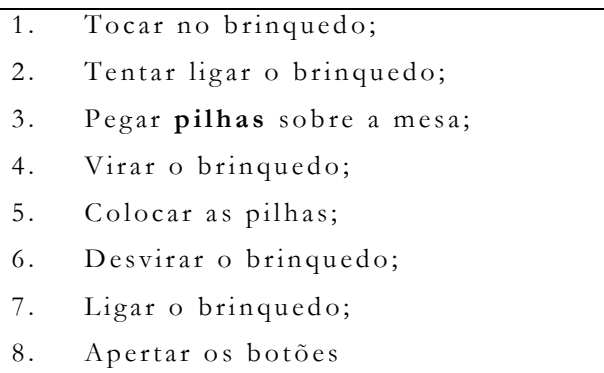 \\
\hline 2. Posto de Gasolina & $\begin{array}{l}\text { 2. Pegar caminhão; } \\
\text { 3. Descer carrinho na rampa. }\end{array}$ \\
\hline $\begin{array}{l}\text { animais. } \\
\text { and }\end{array}$ & $\begin{array}{l}\text { 2. Tirar a peças de dentro do plástico } \\
\text { e colocá-las sobre a mesa; } \\
\text { 3. Montar o quebra-cabeça. }\end{array}$ \\
\hline 4. Boliche & $\begin{array}{l}\text { 2. Colocar o primeiro pino em pé; } \\
\text { 3. Colocar o segundo pino em pé; } \\
\text { 4. Colocar o terceiro pino em pé; } \\
\text { 5. Colocar o quarto pino em pé; } \\
\text { 6. Se afastar dos pinos; } \\
\text { 7. Jogar a bola. }\end{array}$ \\
\hline 5. DVD Teletubies & $\begin{array}{l}\text { 2. Abrir a caixa; } \\
\text { 3. Pegar DVD; } \\
\text { 4. Colocar DVD no aparelho; } \\
\text { 5. Sentar-se na cadeira; } \\
\text { 6. Apertar o play do controle-remoto. }\end{array}$ \\
\hline 6. Papele giz de cera & $\begin{array}{l}\text { 2. Pegar o giz; } \\
\text { 3. Posicionar o papel; } \\
\text { 4. Ligar número } 1 \text { com número } 1 ; \\
\text { 5. Ligar número } 2 \text { com número } 2 ; \\
\text { 6. Ligar número } 3 \text { com número } 3 \text {. }\end{array}$ \\
\hline 7. Bola de sabão & $\begin{array}{l}\text { 2. Pegar tubo da bola de sabão; } \\
\text { 3. Abrir tubo; } \\
\text { 4. Soprar; } \\
\text { 5. Fechar tubo. }\end{array}$ \\
\hline $\begin{array}{l}\text { números } \\
\text { Quebra-cabeça }\end{array}$ & $\begin{array}{l}\text { A. Pegar peças; } \\
\text { 3. Montar o quebra-cabeça }\end{array}$ \\
\hline
\end{tabular}

Nota: Os itens em negrito foram os trabalhados nos Treinos/Testes de Tato e Mando. 
Treino de Tato e Testes de Mando e Tato

$\mathrm{Na}$ Tabela 17, apresenta-se a seqüência do procedimento de treino e testes, para cada par de itens, realizado com o participante T1. Além disso, na mesma Tabela são especificados quais foram os itens utilizados nos testes e nos treinos.

Os Treinos de Tato, por sua vez, foram realizados com cinco itens (pilha, caminhão, bola de boliche, quebra-cabeça de animais e giz de cera), pois já no Pré-Teste dos itens controle-remoto, bola de sabão e quebra-cabeça de números, o participante emitiu tatos para os três estímulos. Assim sendo, não foram realizados os treinos para esses itens/estímulos. 
TABELA 17

Seqüencia dos Treinos e Testes para o Participante T1

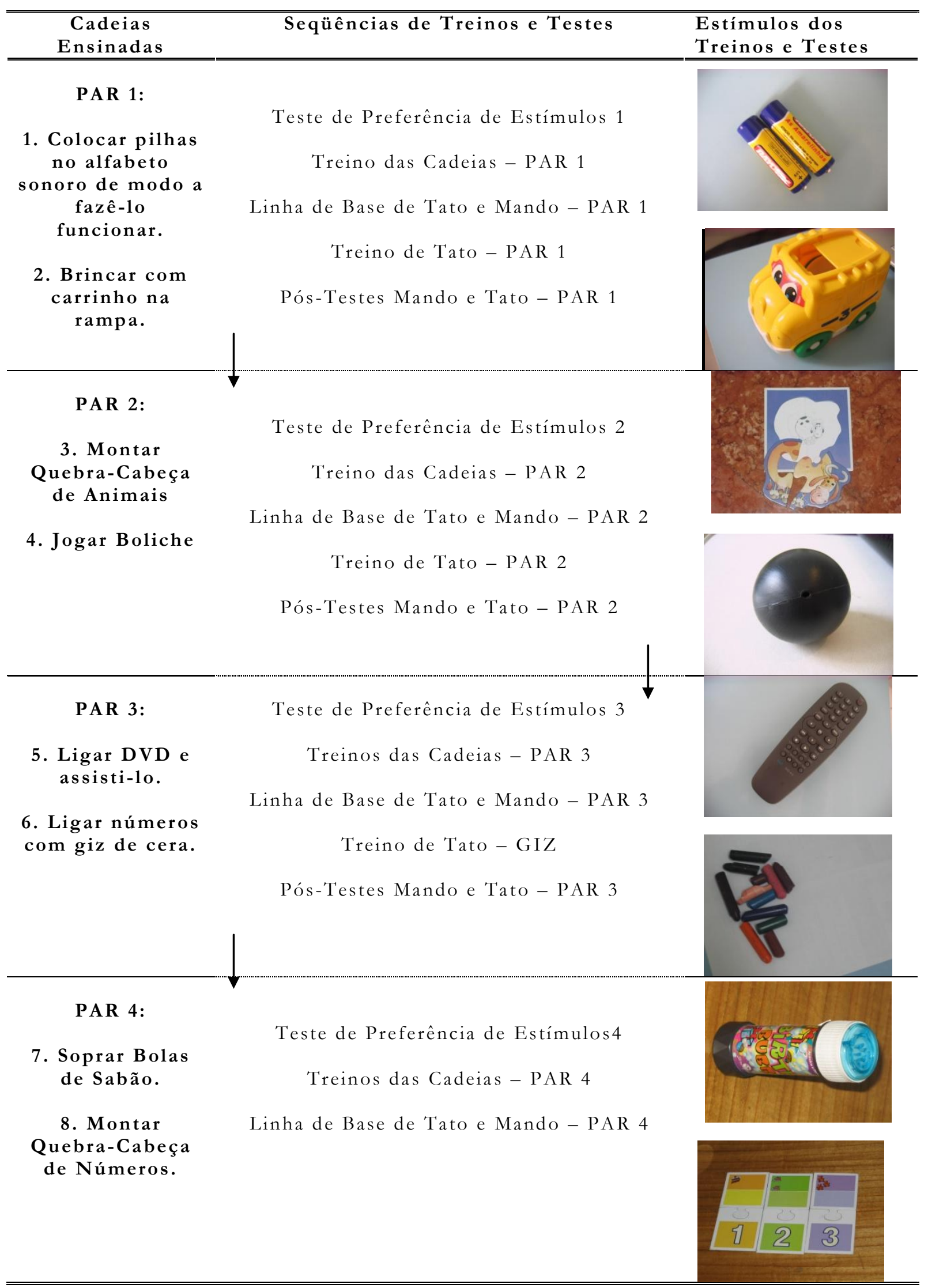




\section{Resultados e Discussão}

Para o Participante 1, foram necessários nove e dez treinos de cadeia para o participante atingir o critério de aprendizagem para as cadeias colocar pilhas no alfabeto sonoro e brincar de carrinho na rampa, respectivamente; seis e oito treinos de cadeia para jogar boliche e montar quebra-cabeça de animais, respectivamente; três e seis treinos de cadeia para ligar DVD e ligar numeros com giz de cera, respectivamente; e três treinos de cadeia para soprar bolinhas de sabão e montar jogo de números.

Na Figura 4 observa-se o desempenho do participante T1 em cada um dos cinco treinos de tato. Na mesma figura, nos gráficos de freqüência acumulada, observa-se a freqüência de acertos acumulados em cada um dos treinos de Tato, bem como distinguem-se as respostas emitidas com dicas (pontos cheios) das respostas emitidas sem dicas ou independentes (pontos vazios) e os erros ou ausência de respostas. No gráfico representado por barras, na mesma figura, é apresentado o total de acertos com dica, acertos independentes e erros, emitidos ao final de cada Treino de Tato. Observa-se que no Treino do primeiro par de tatos (caminhão e pilha) ensinado ao participante, o mesmo precisou de 28 tentativas de treino para cada um dos itens até atingir o critério de aprendizagem. O participante errou em duas tentativas do item pilha e não emitiu erros no Treino de Tato de caminhão. Em 17 tentativas de ensino do item caminhão foi necessária a apresentação de dicas de respostas, enquanto, para o item pilha, foram 13 tentativas com dica de respostas. Por fim, foram emitidas 11 respostas corretas independentes para caminhão, enquanto para pilha foram 13 respostas corretas independentes. 
Observa-se, ainda, que nas primeiras tentativas do Treino de Tato de caminhão e pilha, o participante emitiu mais respostas corretas com dicas. As dicas de respostas foram sendo menos necessárias no decorrer do treino, até o participante atingir o critério de aprendizagem na tarefa (cinco acertos independentes e consecutivos com o item caminhão e três acertos independentes e consecutivos com o item pilha).

O segundo par de itens treinado na condição de tato, com os itens bola e quebra-cabeça, foi finalizado após 16 tentativas de treino, para cada um dos itens. Apenas um erro foi emitido, em uma tentativa de ensino do tato do item bola. Em oito tentativas de ensino de tato de bola foram disponibilizadas dicas de respostas, enquanto no treino do item quebra-cabeca foram sete tentativas com dicas de resposta. Por fim, foram sete e nove tentativas de tatos emitidos de maneira independente, para os itens bola e quebra-cabeça, respectivamente.

Mais uma vez observa-se uma maior freqüência de acertos com dicas de respostas nas primeiras tentativas do treino, enquanto que, ao decorrer do treino, T1 passa a emitir mais respostas corretas independentemente.

Nos último item treinado em tato (giz) foram necessárias apenas quatro tentativas de treino. Já na primeira tentativa de treino, T1 emitiu um acerto independente. 

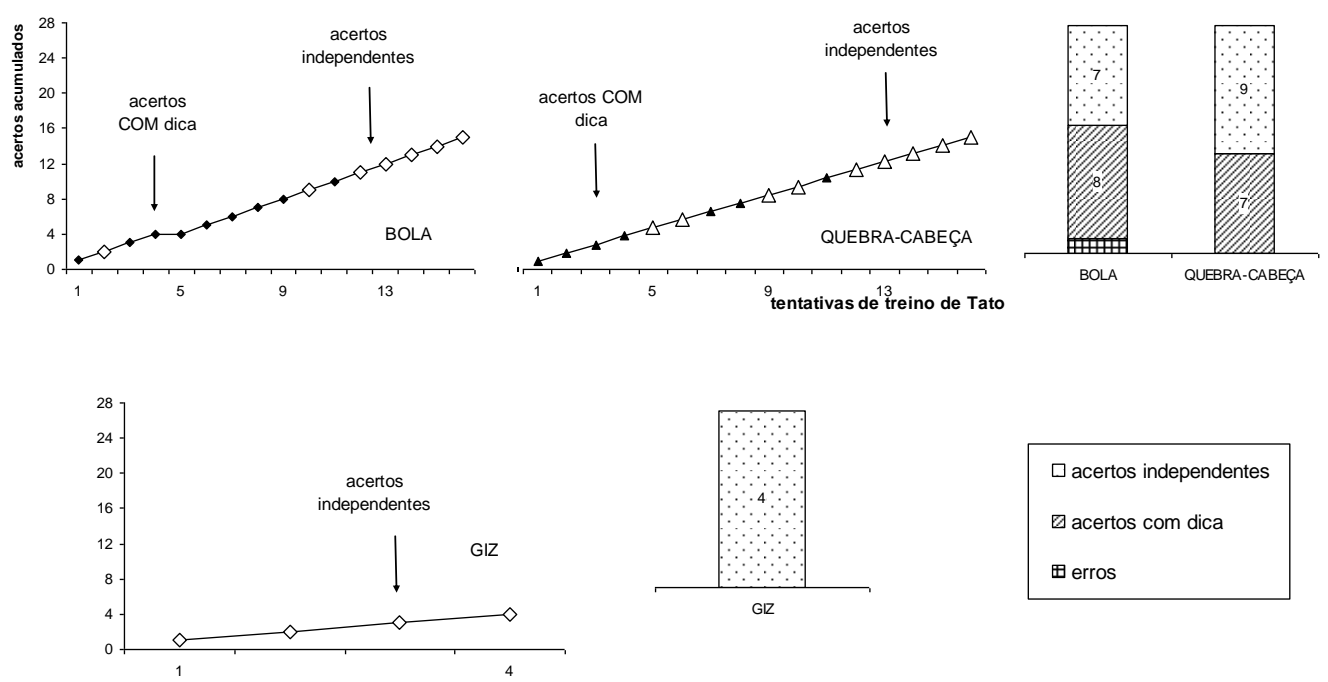

$\square$ acertos independentes

$\square$ acertos com dica

田erros

Figura 4. Desempenho do participante T1 no Treino de Tato dos itens caminhão, pilha, bola, quebra-cabeça e giz.

Na Figura 5 é apresentado o desempenho do participante T1 nas tentativas de Pré-Teste e Pós-Teste.

Em relação ao desempenho do participante T1 no Pré-Teste, verificou-se que os itens caminhão, pilha, bola de boliche, quebra-cabeça de animais e giz. não foram emitidos na condição de teste em tato, nem em mando. No Pré-Teste, quando o participante foi testado a tatear os itens controle-remoto, bola de sabão e quebracabeça de números, o mesmo emitiu respostas para essas topografias em todas as tentativas de teste. Ainda em relação ao Pré-Teste, o participante emitiu Mando em duas tentativas de teste para o item controle-remoto.

O participante T1 emitiu tatos em todas as tentativas do Pós-Teste, para todos os itens, sugerindo manutenção do repertório diretamente treinado. Já no Pós-Teste de Mando, não foram emitidas respostas para a maior parte dos estímulos testados; foram emitidas apenas duas respostas em mando para o item controle-remoto. 


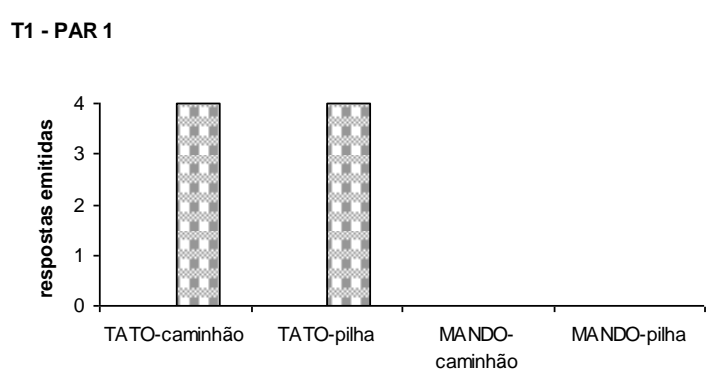

PAR 3

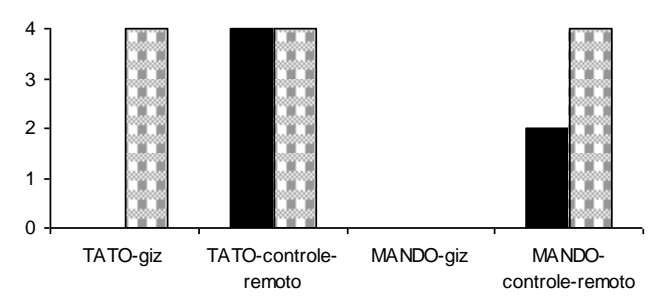

PAR 2

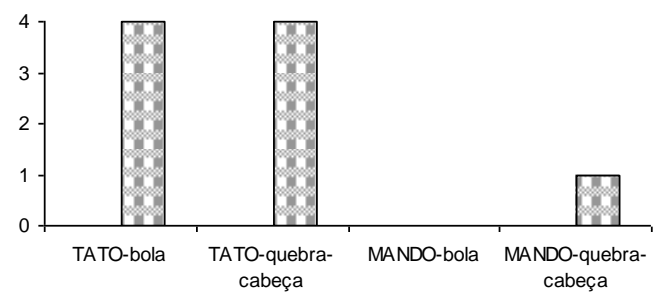

PAR 4

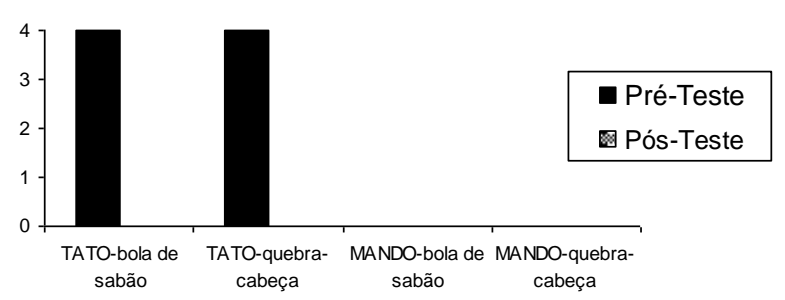

operantes verbais e estímulos

Figura 5. Desempenho do participante T1 no Pré-Teste e Pós-Teste de Tato e Mando dos itens caminhão, pilha, bola, quebra-cabeça, controle-remoto, giz, bola de sabão e quebra-cabeça de números.

Os dados de Pré-Teste e de Pós-Teste indicam que o Treino de Tato foi efetivo para que T1 aprendesse a emitir tatos com os cinco itens (caminhão, pilha, bola de boliche, quebra-cabeça de animais e giz,), com topografias de respostas baseadas na seleção de estímulos.

Além disso, parece ter ocorrido o fenômeno de learning set (ver Figura 4), uma vez que, a cada par de itens treinados, menos tentativas foram necessárias para que T1 atingisse o critério de aprendizado no treino do par seguinte. Por exemplo, o participante precisou de 28 tentativas de treino para o primeiro par de itens; de 16 tentativas de treino para o segundo par de itens; de quatro para um dos itens do terceiro par e nenhum treino foi necessário para que T1 emitisse tatos no outro item do terceiro par, bem como para os itens do quarto par de 
estímulos (uma vez que os Tatos desses itens foram emitidos já na condição de Pré-Teste).

Por fim, observou-se que o ensino de uma determinada topografia na condição de tato não foi suficiente para que a mesma fosse emitida na condição de Mando. Esse dado corrobora achados anteriores (Lamarre \& Holland, 1985, Hall \& Sundberg, 1987, Twyman, 1996) que apontaram independência funcional entre os operantes verbais tato e mando.

No Estudo 1, procuramos identificar se a resposta comum baseada na seleção de estímulos, treinada na condição de tato, poderia ser emitida na condição de mando, sem o treino direto. Existia uma hipótese de que a foto do item (disponível para que a resposta de seleção fosse emitida) pudesse funcionar como um estímulo discriminativo na condição de mando (além das operações estabelecedoras previstas no operante mando).

O Estudo 1 parece ter sido importante, também, para estender os achados de Ziomek e Rehfeldt (2008) de independência funcional entre operantes tato e mando para respostas verbais baseadas na seleção de estímulos. 
Uma vez observada, no Estudo 1, a independência funcional entre os operantes tato e mando com respostas baseadas na seleção de estímulos; no Estudo 2, buscou-se identificar variáveis que poderiam facilitar que uma mesma resposta ensinada em uma determinada condição (ou tato ou mando), fosse emitida sob controle de outros estímulos, sem o treino direto. Mais especificamente, foi investigado o efeito dos treinos de tato (para o participante T2) e mando (para os participantes M1 e M2) com conseqüências adicionadas às previstas pelos operantes verbais: elogios, para Mando e, aquisição de um brinquedo, para tato.

Assim sendo, no Estudo 2, investigou-se:

1) O efeito do treino de uma topografia verbal em tato, no Pós-Teste de mando, quando, a cada emissão de tato, durante o treino, era apresentado ao participante, além do elogio, um reforço condicionado (um brinquedo, que não o descrito pelo operante tato);

2) O efeito do treino de uma topografia verbal em mando, no Pós-Teste de Tato, quando a cada emissão de mando, o participante era elogiado pelo experimentador, além de obter o item específico (previsto pelo operante mando).

Caso o treino de um dado operante verbal com consequëncias adicionadas pudesse favorecer a emissão de um segundo operante, nunca anteriormente treinado, poder-se-ia dizer que o treino de um único operante verbal seria efetivo para que dois operantes fossem emitidos. 


\section{Método}

\section{Participantes}

T2, M1 e M2 foram os participantes desse estudo. Na Figura 6 são apresentados os escores obtidos por eles por ocasião da coleta de dados, na Avaliação de Linguagem (Sundberg \& Partington, 1998). Observa-se que T2 e M1 obtiveram escores mais baixos no repertório que envolve categorizações auditivo-visuais por função, característica ou classe. Enquanto T2 obteve escore mais baixo para habilidades envolvendo letras e números, M1 apresentou baixo escore para interação social. Os escores das demais habilidades variaram entre os escores 4 e 5, tanto para T2 quanto para M1. Já M2, por sua vez, não obteve escore maior que 3 em nenhum dos repertórios avaliados.

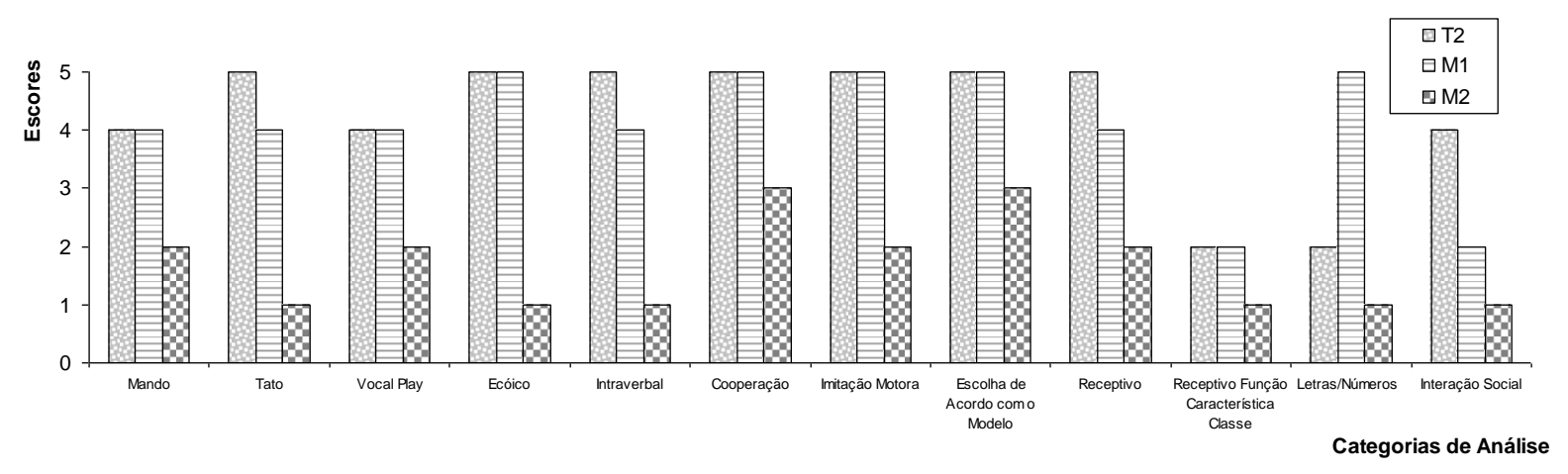

Figura 6. Escores obtidos pelos participantes T2, M1 e M2 na Avaliação de Linguagem proposta por Sundberg e Partington (1998).

Uma descrição mais detalhada dos repertórios comportamentais dos participantes é apresentada nas Tabelas 18, 19 e 20. Em cada uma dessas tabelas, especifica-se a quais estímulos cada um dos participantes respondiam, em cada um dos repertórios avaliados. 
TABELA 18

Repertório Comportamental do Participante T2, na ocasião da coleta dos dados

Mando: Emitia pedidos com as verbalizações me dá, eu quero, diante de cinco a dez itens reforçadores presentes (DVD de filmes e brinquedos).

Tato: Nomeava ações do cotidiano (tomar banho, comer, pular, brincar, etc.), personagens de desenhos animados e filmes, pessoas familiares e colegas de sala de aula.

Vocal Play: Emitia vocalizações freqüentes, com entonações variadas, por exemplo, cantarolava músicas.

Ecóico: Repetia qualquer palavra ou frase (simples) emitidas por outro.

Intraverbal: Respondia adequadamente quando questionado quanto ao nome de pessoas familiares e seu próprio nome, falava os dias da semana na seqüencia correta, bem como os meses do ano. Além disso, cantava trechos de músicas infantis.

Cooperação com adultos: Permanecia por dez minutos, sem apresentar comportamentos disruptivos, em condição de demanda.

Imitação Motora: Imitava facilmente qualquer movimento de coordenação motora fina ou grossa de maneira espontânea, principalmente em atividades reforçadoras como na aula de natação ou educação física.

Escolha de acordo com o modelo: Emparelhava estímulos tridimensionais ou bidimensionais iguais entre si (brinquedos, bonecos, pessoas, letras e números).

Repertório Receptivo: Seguia muitas instruçôes e apontava para mais de 100 itens, ações, pessoas ou adjetivos.

Repertório Receptivo por Função, Característica ou Ciasse: Comportava-se como um ouvinte diante de instruções aponte para o animal, aponte para o que é de comer/beber.

Letras e números: Identificava e nomeava os números 1,2 e 3 ; também identificava e nomeava as letras / P/, /E/ e /O/.

Interação social: Com a ajuda de um adulto, chamava crianças da escola para brincar e cumprimentava pessoas (vocalizava oi).

Nota: Repertório comportamental classificado de acordo com a Avaliação de Linguagem de Sundberg e Partington (1998). 
TABELA 19

Repertório Comportamental do Participante M1, na ocasião da coleta dos dados

Mando: Emitia de cinco a dez palavras para pedir por reforçadores. Vocalizava, por exemplo, me dá, vídeo, pintar, montar e outros.

Tato: Nomeava personagens preferidos, açốs do cotidiano, familiares e objetos de seu cotidiano.

Vocal Play: Repetia, com freqüência, falas de filmes e trechos de músicas preferidas.

Ecóico: Repetia qualquer palavra ou frases simples emitidas por outro.

Intraverbal: Era capaz de completar/continuar 20 frases ou responder a 20 questốes simples. Por exemplo: respondia às questões como qual o seu nome?, qual o nome de sua mãe?, quantos anos você tem?, etc.

Cooperação com adultos: Trabalhava bem numa mesa, em situação de demanda, por dez minutos, sem comportamentos disruptivos.

Imitação Motora: Imitava facilmente qualquer movimento de coordenação motora fina ou grossa, de maneira espontânea (sem ser solicitado para tanto).

Escolha de acordo com o modelo: Emparelhava diversas figuras e/ou objetos iguais entre si, números, letras e palavras. Além disso, emparelhava estímulos arbitrários como os números de um à cinco, com suas respectivas quantidades.

Repertório Receptivo: Seguia muitas instruçốs e apontava para pelo menos 25 itens (objetos, personagens de filmes, etc.).

Repertório Receptivo por Função, Característica ou Classe: Identificava poucos objetos frente a verbalizações de sinônimos ou função dos mesmos.

Letras e números: Nomeava e identificava pelo menos 25 palavras simples da língua portuguesa e identificava os numerais de um à dez.

Interação social: M1 aproximava-se fisicamente de adultos familiares para iniciar uma interação social. No entanto, não emitia verbalizações para iniciar uma interação social.

Nota: Repertório comportamental classificado de acordo com a Avaliação de Linguagem de Sundberg e Partington (1998). 
TABELA 20

Repertório Comportamental do Participante M2, na ocasião da coleta dos dados

Mando: Puxava as pessoas, apontava ou se posicionava a frente de itens reforçadores, para aquisição dos mesmos.

Tato: Não nomeava nenhum objeto, ação, personagens, etc.

Vocal Play: Emitia poucas, mas freqüentes, vocalizações de sons de letras/sílabas reconhecíveis como os da língua portuguesa, normalmente acompanhadas de estereotipias motoras.

Ecóico: Não repetia qualquer som ou palavra emitida por outro.

Intraverbal: Não era capaz de completar/continuar palavras, expressões ou frases iniciadas por outro.

Cooperação com adultos: Emitia até cinco respostas em condição de demanda, sem apresentar um comportamento disruptivo, com estímulos reforçadores sendo apresentados após a emissão de cada resposta.

Imitação Motora: Imitava movimentos simples de coordenação motora grossa, como bater palmas, levantar os braços e colocar as mãos sobre a mesa.

Escolha de acordo com o modelo: Emparelhava figuras de alimentos (banana, morango e cenoura) iguais entre si, bem como de objetos familiares a M2 como lego, caneta e carrinho.

Repertório Receptivo: Seguia até cinco instruções de açốes relacionadas às atividades da rotina. Por exemplo, seguia aos comandos dê descarga, lave as suas mãos, seque as suas mãos, jogue no lixo.

Repertório Receptivo por Função, Característica ou Classe: Não era capaz de identificar (apontar) itens a partir de informações verbais dadas sobre os mesmos.

Letras e números: Não nomeava, nem identificava letras (apontava para letra ditada pelo experimentador) e também não emitia tais respostas diante de estímulos numéricos.

Interação social: Não iniciava qualquer interação social com outros.

Nota: Repertório comportamental classificado de acordo com a Avaliação de Linguagem de Sundberg e Partington (1998). 
Procedimentos prévios e treino de pré-requisitos - Teste de Preferência de Estímulos (De Leon \& Iwata, 1996) e Treino de Cadeias Comportamentais (Hall \& Sundberg, 1987)

Foi realizado com cada um dos participantes (T2, M1 e M2) um Teste de Preferência de Estímulos de DeLeon e Iwata (1996) e foi ensinado a cada um deles a completar duas cadeias comportamentais, apresentados na Tabela 21.

Observa-se que as cadeias comportamentais são diferentes entre e intra participantes, com exceção de T2 e M1, que escolheram o mesmo brinquedo (encaixe de formas) no Teste de Preferência de Estímulos (DeLeon \& Iwata, 1996). Essa diferença ocorreu para contemplar a diversidade dos estímulos escolhidos por cada um dos participantes.

Treinos e Testes de Tato (para T2) e Mando (para M1 e M2)

Conforme apresentado na Tabela 22, T2 foi ensinado a emitir Tatos de dois itens e M1 e M2 foram ensinados a emitir mandos de dois itens cada um. Na Tabela 22, pode-se observar a seqüencia dos treinos e testes, para cada par de itens, realizada com cada um dos participantes. Além disso, na mesma tabela são especificados quais foram os itens utilizados nos testes e nos treinos dos operantes tato e mando com T2, M1 e M2.

Os testes de tato e mando realizados com os participantes foram conduzidos conforme descrição na sessão Método Geral. 
TABELA 21

Itens Preferidos pelos Participantes T2, M1 e M2 no Teste de Preferência de Estímulos (De Leon \& Iwata, 1996) e Cadeias Comportamentais (Hall \& Sundberg, 1987) desenvolvidas e ensinadas para T2, M1 e M2

\begin{tabular}{|c|c|c|}
\hline Participantes & Itens Preferidos & Tarefas da Cadeia Comportamental \\
\hline T2 & Encaixe de Formas & $\begin{array}{l}\text { 1. Tocar na roda; } \\
\text { 2. Ligar o botão; } \\
\text { 3. Pegar elefante; } \\
\text { 4. Colocar elefante na cadeira; } \\
\text { 5. Girar a roda } \\
\text { 1. Abrir a porta do brinquedo; } \\
\text { 2. Pegar as formas dentro do brinquedo; } \\
\text { 3. Fechar a porta; } \\
\text { 4. Encaixar a primeira forma; } \\
\text { 5. Girar a manivela; } \\
\text { 6. Encaixar a segunda forma; } \\
\text { 7. Girar a manivela; } \\
\text { 8. Encaixar a terceira forma } \\
\text { 9. Girar a manivela; } \\
\text { 10. Encaixar a quarta forma; } \\
\text { 11. Girar a manivela. }\end{array}$ \\
\hline M1 & Encaixe de Formas & $\begin{array}{l}\text { 1. Pegar a pasta; } \\
\text { 2. Abrir a pasta; } \\
\text { 3. Pegar o livro; } \\
\text { 4. Folhar o livro. } \\
\text { Idem T2. }\end{array}$ \\
\hline M2 & Bola de borracha verde. & $\begin{array}{l}\text { 1. Pegar pote; } \\
\text { 2. Desrosquear a tampa; } \\
\text { 3. Pegar a bola; } \\
\text { 4. Apertar a bola por } 3 \text { vezes. } \\
\text { 1. Pegar o boneco; } \\
\text { 2. Colocar no carrinho; } \\
\text { 3. Empurrar o carrinho. }\end{array}$ \\
\hline
\end{tabular}

Nota: Os itens em negrito foram os trabalhados nos Treinos/Testes de Tato e Mando. 
TABELA 22

Seqüencia dos Treinos e Testes para os Participantes T2, M1 e M2

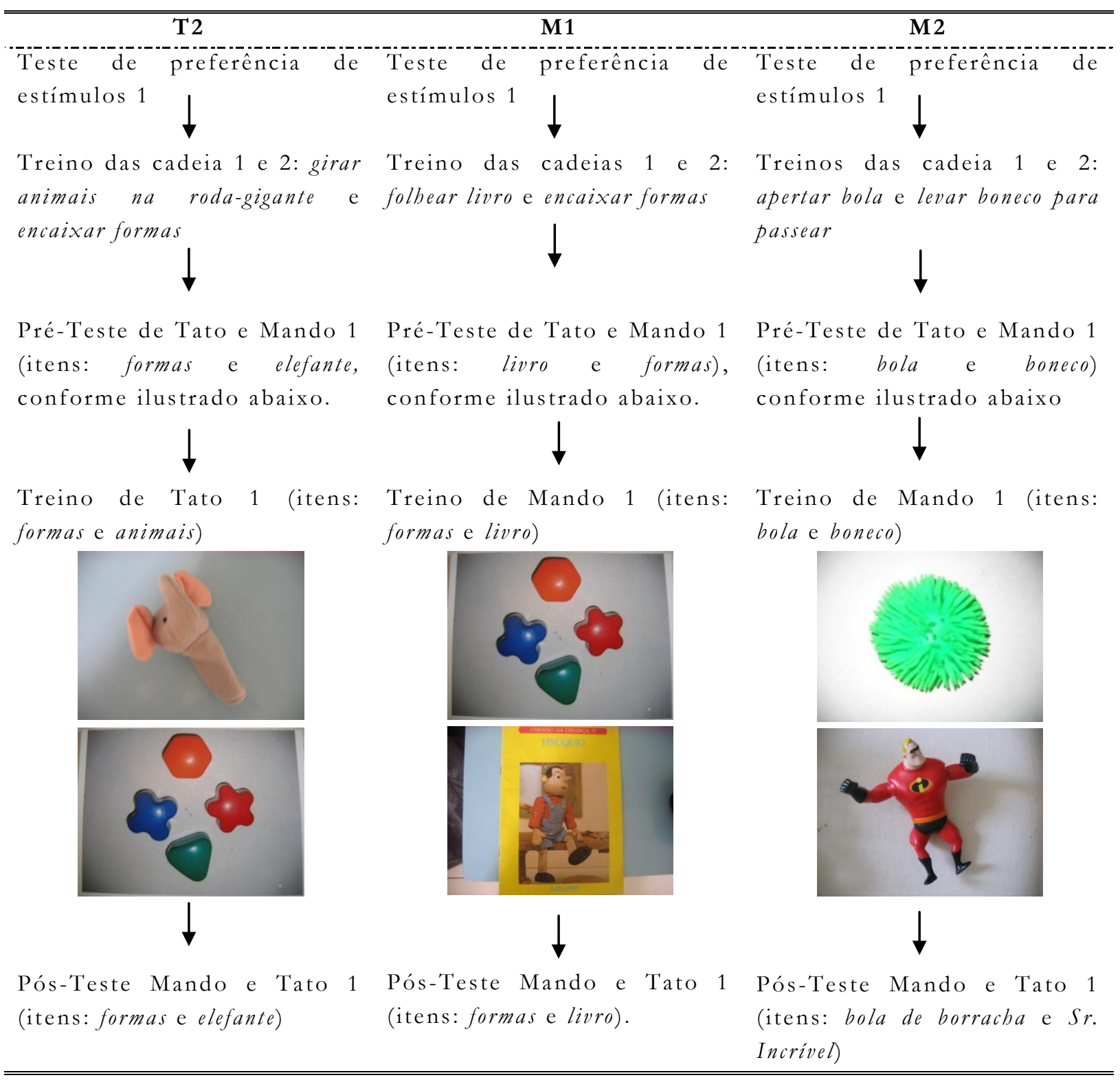

Na Figura 7 foi esquematizado o treino dos operantes tato e mando para destacar os antecedentes e conseqüentes às respostas no Estudo 2. No Treino de Tato, realizado com o participante T2, foram disponibilizadas duas conseqüências para o responder do participante: (a) elogio (previsto na própria definição do operante) e (b) apresentação de um brinquedo (não o brinquedo ao qual seria emitido um tato, mas um outro brinquedo, que deveria ter a função de um reforçador condicionado) para o participante. Essa última conseqüência foi 
disponibilizada por dois motivos: primeiro, para verificar o efeito da mesma no teste do operante mando; segundo, por uma necessidade prática ou, em outras palavras, o brinquedo apresentado como reforçador condicionado mantinha o participante sentado à mesa de atividades durante as sessões de ensino, tornando a atividade mais reforçadora para o responder do mesmo (e evitou comportamentos disruptivos durante o treino).

O Treino de Mando, realizado com os participantes M1 e M2, foi o mesmo descrito na sessão Método Geral, com a seguinte diferença: além dos participantes obterem o item específico após a emissão do mando, o experimentador disponibilizava um reforço generalizado, neste caso, um elogio.

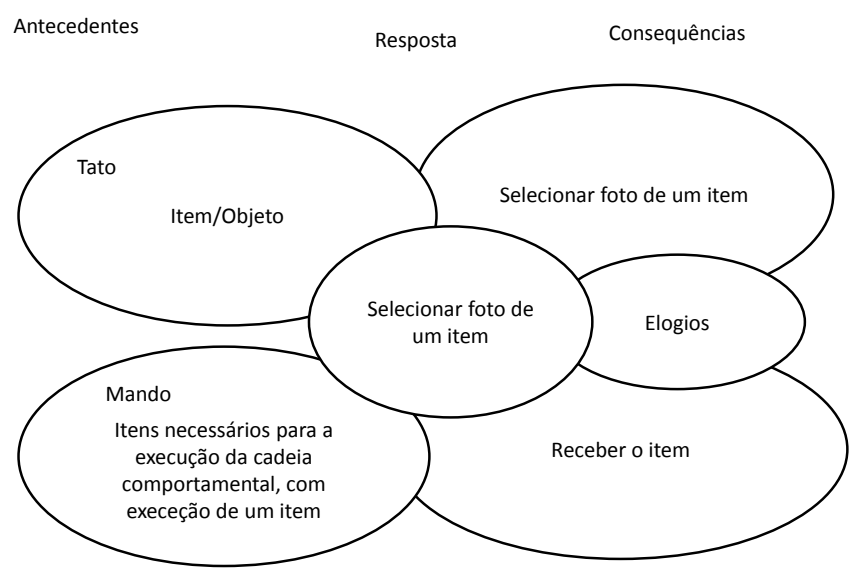

Figura 7. Esquema dos Operantes Tato e Mando com seus respectivos Antecedentes e Conseqüentes, no Estudo 2. 
Todos os participantes deste estudo aprenderam a desenvolver as cadeias comportamentais descritas na Tabela 21. Embora as cadeias desenvolvidas fossem diferentes intra e entre participantes, o aprendizado das mesmas parece não ter sido influenciado por tal diferença.

$\mathrm{Na}$ Tabela 23 é apresentado o número de vezes em que cada uma das cadeias comportamentais foi treinada por cada um dos participantes até que os mesmos atingissem o critério de aprendizagem na tarefa.

TABELA 23

Número de vezes que cada uma das Cadeias Comportamentais foi treinada com os Participantes T2, M1 e M2

\begin{tabular}{ccc}
\hline \hline Participantes & Cadeias Comportamentais & Tentativas de Treino \\
\hline \hline T2 & Roda-Gigante & 5 \\
Encaixe de Formas & 5 \\
\hline L1 & Livero & 3 \\
M2 & Bola de borrachaverde. & 3 \\
\hline \hline
\end{tabular}

$\mathrm{Na}$ Figura 8 é apresentado o desempenho dos participantes T2 (no primeiro painel de gráficos), M1 (segundo painel de gráficos) e M2 (terceiro painel de gráficos), nos Treinos de Tato (T2) e Mando (M1 e M2).

Nos gráficos de freqüência acumulada, observam-se os acertos emitidos pelos participantes nos treinos. Os pontos cheios representam acertos com dicas 
de respostas e os pontos vazios representam os acertos sem dicas de resposta, ou seja, independentes.

Em cada gráfico de barras é apresentado o número total de acertos com dicas, acertos independentes e o número de erros emitidos por cada um dos participantes nos treinos.

Os dados apresentados na Figura 8 indicam que o treino foi efetivo para o que os participantes emitissem os operantes tato (T2) e mando (M1 e M2).

Na Figura 8, observa-se o desempenho dos participantes em cada tentativa do treino. No tocante aos acertos com dica de resposta, T2 emitiu 13 e 11 acertos com dica (de um total de 24 tentativas de treino), para os itens formas e elefante, respectivamente. M1 emitiu três e dois acertos com dicas (de um total de oito tentativas), para os itens livro e formas, respectivamente. M2, por sua vez, emitiu sete acertos (de um total de 16 tentativas) com dicas para ambos os itens bola e boneco.

Em relação aos acertos independentes, observou-se que T2 emitiu 11 e 13 acertos independentes (de um total de 24 tentativas de treino), para os itens formas e elefante, respectivamente. M1 emitiu seis e quatro acertos independentes (de um total de 16 tentativas) para ambos os itens livro e formas, respectivamente. M2 emitiu nove acertos independentes para ambos os itens bola e boneco, de um total de 16 tentativas de treino.

Nenhum dos participantes emitiu erros durante os treinos.

Observa-se, por fim, que os participantes T2, M1 e M2 foram expostos a 24, oito e 16 tentativas de treino, respectivamente, até atingirem o critério de aprendizagem na tarefa. 

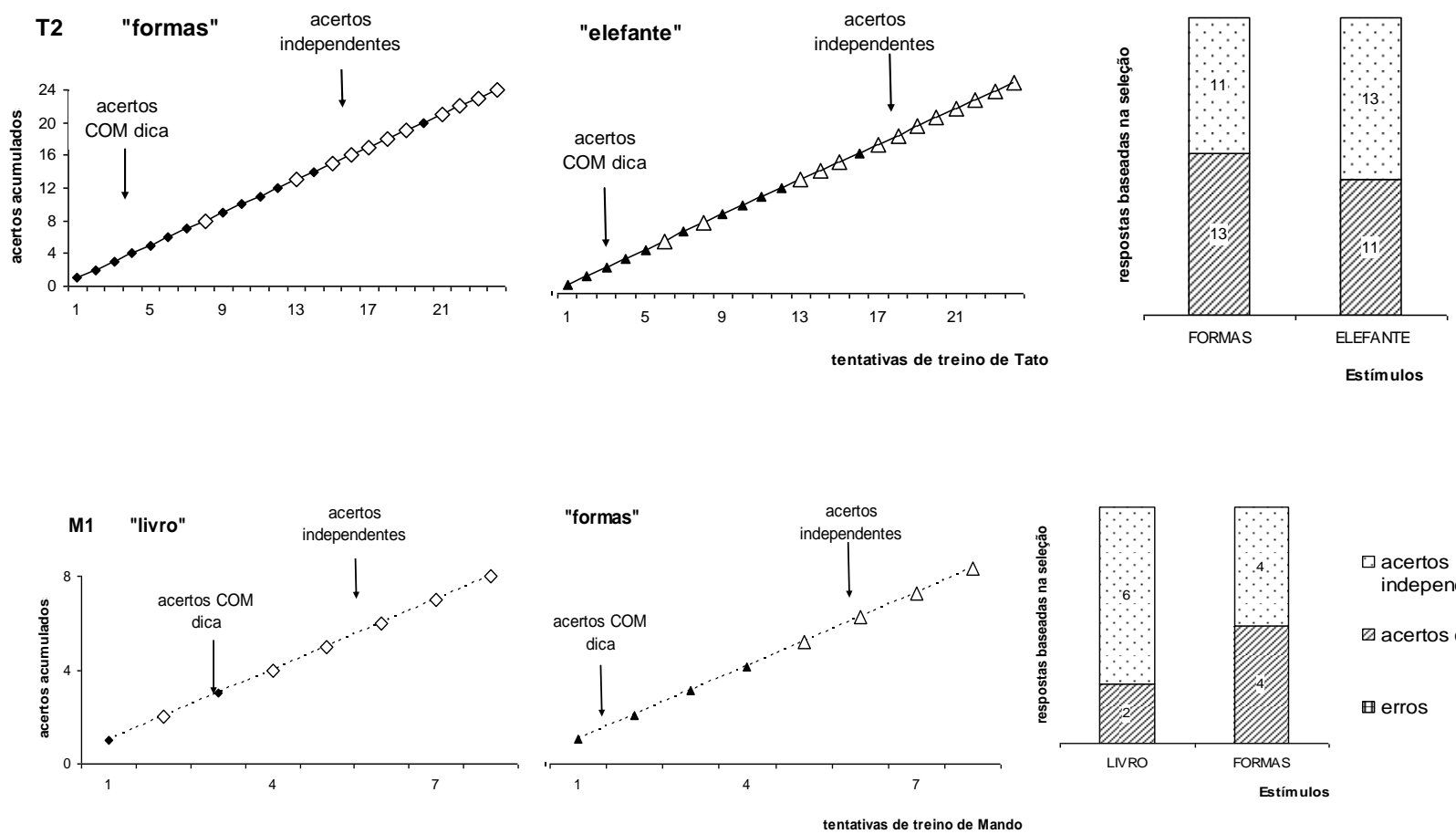

$\square$ acertos independentes

acertos com dica $\mathbb{\mathbb { B }}$ erros
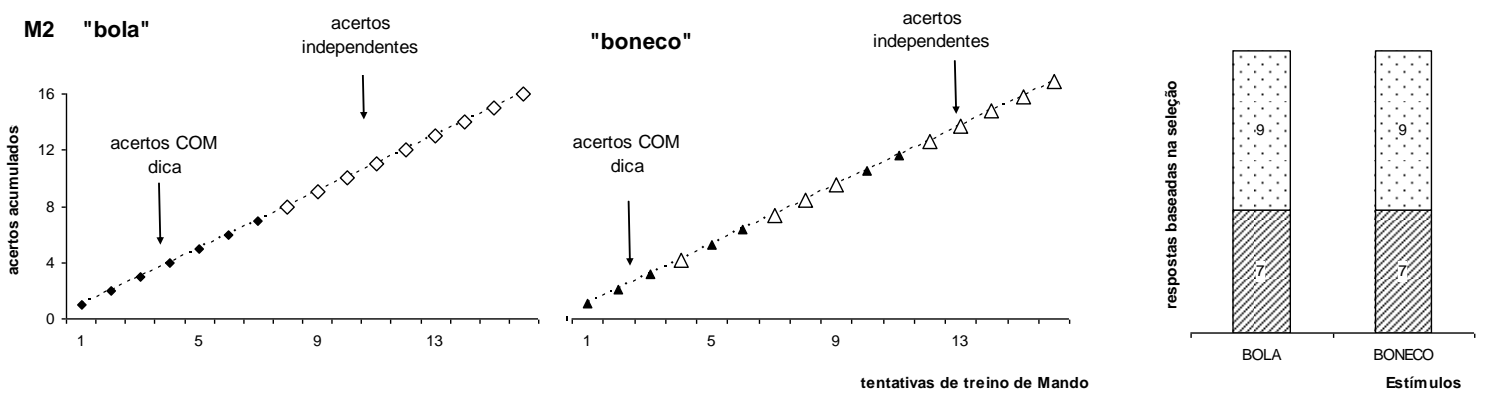

Figura 8. Desempenho dos participantes T2, M1 e M2 no treino dos operantes tato (T2) e mando (M1 e M2).

$\mathrm{Na}$ Figura 9 apresenta-se o desempenho dos participantes nos testes de mando e tato para cada par de estímulos testados, tanto no Pré-Teste quanto no Pós-Teste. Conforme ilustrado na Figura 7, observa-se que nenhum dos participantes emitiu tatos ou mandos nas tentativas de Pré-Teste.

Já nas tentativas de Pós-Teste (com os itens formas e elefante) quando T2 foi exposto às operações estabelecedoras, o mesmo emitiu mandos, sem o treino 
direto. Os participantes M1 e M2, quando expostos aos estímulos discriminativos do tato, no Pós-Teste, emitiram tais respostas sem treino direto.

Por fim, observa-se que todos os operantes ensinados diretamente aos participantes foram emitidos na condição de Pós-Teste (apenas T2 emitiu um Tato errado - de três tentativas - para o item formas no Pós-Teste). Esses dados demonstram, mais uma vez, que o treino foi efetivo para que os participantes adquirissem o repertório verbal previamente definido.

Além disso, os dados do Pós-Teste (acertos nas tentativas de teste do operante diretamente treinado) parecem sugerir que o critério de aprendizagem (três acertos consecutivos, independentes, para cada um dos itens treinados), descrito na presente pesquisa, foi adequado para garantir que o repertório em treino fosse realmente estabelecido.

Observa-se que para todos os participantes, o treino do operante verbal com conseqüências comuns parece ter sido suficiente para que os mesmos emitissem respostas corretas nos testes do operante não diretamente treinado. Em outras palavras, T2 emitiu mandos no Pós-Teste tendo sido treinado a emitir tatos; M1 e M2 emitiram tatos no Pós-Teste, tendo sido treinados a emitir mandos, com a mesma topografia.

T2

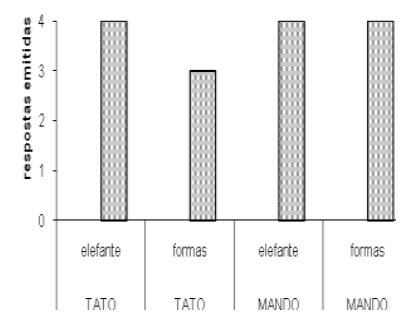

m1

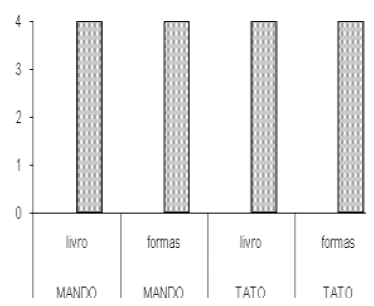

M2

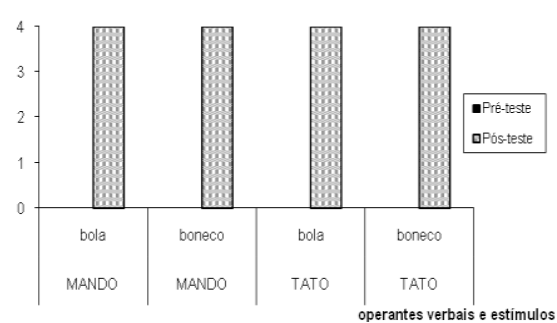

Figura 9. Desempenho dos participantes T2, M1 e M2 no Pré-Teste e Pós-Teste para cada par de itens testado. 
Assim, observou-se que o participante T2 fora ensinado e emitir tatos (selecionar a foto correspondente) para os estímulos formas e elefante, na presença dos próprios itens. A conseqüência para o responder de T2 foi a emissão de um elogio, emitido pelo experimentador e um brinquedo (que não aquele tateado pelo participante). Diferentemente do participante do Estudo 1 (T1), T2 emitiu mandos diante das operações estabelecedoras sem o treino direto da topografia verbal na condição de mando. A variável importante para esse achado parece ter sido o acréscimo do brinquedo ou estímulo reforçador condicionado como conseqüência no Treino de Tato.

Ainda em relação ao Estudo 2, observou-se que o Treino de Mando, com o acréscimo de elogios às conseqüências do responder pareceu favorecer os participantes M1 e M2 emitirem tatos, sem o treino direto desse operante (sem o controle dos estímulos discriminativos que antecedem respostas de tato), com a mesma topografia verbal.

Comparando os resultados do Estudo 1 com os resultados obtidos no Estudo 2, verificou-se que o ensino dos operantes tato e mando, sob controle de conseqüências comuns, parece ser mais econômico e eficiente para produzir novos operantes verbais.

Além disso, quando comparamos o número de tentativas necessárias para o aprendizado da tarefa entre os participantes do Estudo 1 e do Estudo 2, notase que foram necessárias menos tentativas de treino para T2, M1e M2 (pelo menos no primeiro par de itens treinados), do que para T1, que foi treinado sob condições de "tato puro"33".

Por fim, observa-se que a particularidade dos repertórios dos participantes (Avaliação de Linguagem, Sundberg \& Partington, 1998) não pareceu interferir

33 Entende-se por "tato puro" "Um tacto estabelecido com um reforço completamente generalizado pode ser chamado de "puro" ou de “objetivo."(Skinner, 1957/1992, p. 83). 
nos desempenhos dos participantes do Estudo 2, nem nos treinos, nem nos testes: Todos os participantes aprenderam as tarefas treinadas, bem como emitiram respostas verbais não treinadas. Esse dado permite-nos hipotetizar que o treino, tal como proposto no Estudo 2, é eficaz para produzir novas respostas verbais em crianças diagnosticadas com autismo, com padrões comportamentais distintos: M2 era uma criança com repertório comportamental mais deficitário que M1 e T2 e, ainda assim, o treino beneficiou-o tanto quanto aos outros participantes (ver Figura 7). 
Estudo 3

No Estudo 2, foi observado que as respostas treinadas em tato foram emitidas na condição de mando no Pós-Teste, sem o treino direto; e as respostas treinadas em mando foram emitidas na condição de tato no Pós-Teste, também sem treino direto. Tal fenômeno parece ter sido observado uma vez que, no Estudo 2, as conseqüências produzidas nos treinos de cada um desses operantes foram manipuladas (a cada emissão de tato T2 recebia um reforço condicionado/brinquedo, além de um elogio e, a cada emissão de mando, M1 e M2 recebiam, além do item especificado na forma da resposta, um elogio).

O Estudo 3, por sua vez, teve como objetivo investigar o efeito do pareamento entre a topografia vocal do mando emitida pelo experimentador durante o treino de mando, na aquisição do mando e na aquisição (ou não) do tato.

A resposta verbal vocal foi emitida pelo experimentador por três motivos: (a) verificar o efeito da mesma na aquisição de repertório de mando; (b) verificar o efeito da mesma no repertório de tato (operante não diretamente treinado); (c) verificar o efeito da mesma no repertório verbal vocal do participante M3 (operantes tato e mando). 


\section{Método}

\section{Participantes}

Foi participante deste estudo M3. Na Figura 10 apresentam-se os escores obtidos pelo participante M3, na ocasião da coleta de dados, na Avaliação de Linguagem (Sundberg \& Partington, 1998). Observa-se que as habilidades mais deficitárias no repertório de M3 centravam-se nas habilidades de pareamento de acordo com o modelo, identificação, nomeação e relações com letras, palavras e números e interação social. Por outro lado, o vocal play e o ecóico eram os repertórios mais desenvolvidos em M3.

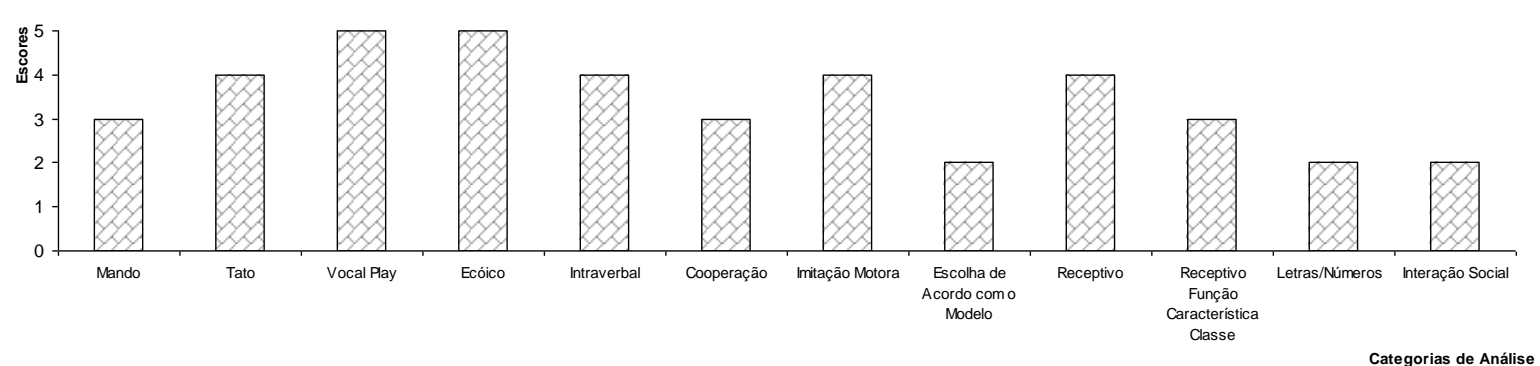

Figura 10. Escores obtidos pelo participante M3 na Avaliação de Linguagem proposta por Sundberg e Partington (1998).

Uma descrição mais detalhada do repertório comportamental de M3 na ocasião da coleta de dados é apresentada na Tabela 24; especifica-se a quais estímulos o participante M3 respondia, em cada um dos repertórios avaliados. 
TABELA 24

Descrição do Repertório Comportamental de M3, na ocasião da coleta dos dados

Mando: Utilizava gestos (apontar ou levar a adulto até o item) para solicitar um item reforçador e verbaliza ua para solicitar por água e que quando queria pedir por pão-dequeijo.

Tato: Nomeava personagens de filmes e de desenhos animados, figuras em livros infantis, nomeava apenas a ação caiu, quando um objeto era derrubado ou caía, nomeava alguns animais e algumas cores.

Vocal Play: Emitia vocalizações freqüentes, com entonações variadas, muitas irreconhecíveis enquanto palavras.

Ecóico: Repetia qualquer palavra emitida por um adulto familiar.

Intraverbal: Continuava trechos de músicas iniciadas por um adulto; músicas estas, familiares ao participante. Também verbalizava a última sílaba ou palavras de algumas parlendas e expressões verbais como 1,2, 3 e já.

Cooperação com adultos: Emitia até cinco respostas em condição de demanda, sem apresentar um comportamento disruptivo.

Imitação Motora: Imitava vários movimentos de coordenação motora (fina ou grossa) quando requisitado. Por exemplo, imitava coreografias de músicas.

Escolha de acordo com o modelo: Emparelhava uma ou dus figuras e/ou objetos iguais entre si.

Repertório Receptivo: Ídentificava objetos utilizados em seu cotidiano (fralda, roupas, sapatos), frutas, alimentos de maneira geral, pessoas, personagens de filmes e desenho animado, etc.

Repertório Receptivo por função, característica ou classe: Identificava os diferentes meios de transportes, frutas e animais.

Letras e números: Identificava e nomeava os números 1,2 e 3 .

Interação social: Iniciava interaçôes sociais se aproximando fisicamente do outro.

Nota: Repertório comportamental classificado de acordo com a Avaliação de Linguagem de Sundberg e Partington (1998). 
Procedimentos Prévios e Treino de Pré-requisitos - Teste de Preferência de Estimulos (De Leon \& Iwata, 1996) e Treino de Cadeias Comportamentais (Hall \& Sundberg, 1987)

Foram realizados com o participante M3 dois Testes de Preferência de Estímulos e foi-lhe ensinado a completar quatro cadeias comportamentais.

Na Tabela 25 são apresentados os itens escolhidos no Teste de Preferência de Estímulos (primeira coluna), bem como as cadeias comportamentais desenvolvidas e ensinadas para os participantes (segunda coluna).

TABELA 25

Itens Preferidos pelo Participante M3 no Teste de Preferência de Estímulos (De Leon \& Iwata, 1996) e Cadeias Comportamentais (Hall \& Sundberg, 1987) desenvolvidas e ensinadas para $M 3$

\begin{tabular}{|c|c|}
\hline Itens preferidos & Tarefas das Cadeias Comportamentais \\
\hline 1. Quebra-gelo & $\begin{array}{l}\text { 1. Pegar a caixa; } \\
\text { 2. Abrir a caixa; } \\
\text { 3. Pegar a base do brinquedo; } \\
\text { 4. Retirar os cubos de gelo da caixa } \\
\text { 5. Encaixar os cubos de gelo na base; } \\
\text { 6. Encaixar o urso; } \\
\text { 7. Martelar até o urso cair. }\end{array}$ \\
\hline 2. Pula-pirata & $\begin{array}{l}\text { 1. Abrir a caixa; } \\
\text { 2. Pegar o barril, as espadas e o pirata; } \\
\text { 3. Encaixar o pirata; } \\
\text { 4. Encaixar as espadas, uma a uma; } \\
\text { 5. Ver o pirata pular. }\end{array}$ \\
\hline $\begin{array}{l}\text { Einstein } \\
\text { Ein Baby- }\end{array}$ & $\begin{array}{l}\text { 2. Assistir ao DVD } \\
\text { 24 }\end{array}$ \\
\hline $\begin{array}{l}\text { Quckyardigans } \\
\text { backe }\end{array}$ & $\begin{array}{l}\text { 2. Tirar a peças de dentro da caixa e coloca-las sobre a } \\
\text { mesa; } \\
\text { 3. Montar o quebra-cabeça. }\end{array}$ \\
\hline
\end{tabular}

Nota: Os itens em negrito foram os trabalhados nos Treinos/Testes de Tato e Mando.

\footnotetext{
${ }^{34}$ Nesta cadeia especificamente, o DVD/filme já estava ligado à televisão, em "pause", mas com a televisão desligada. Uma vez sentado à cadeira, o participante selecionava a foto da capa do DVD e a entregava para o experimentador. A TV era, então, ligada e o filme era assistido pelo participante (obtenção do item reforçador).
} 
Treinos e Testes de Mando

Conforme apresentado na Tabela 25, foi ensinado a M3 a emitir mandos de quatro itens. Na Tabela 26, pode-se observar a seqüência dos treinos e testes, para cada par de itens, realizada com o participante, bem como os itens utilizados nos testes e nos treinos do operante Mando.

TABELA 26

Seqüência dos Treinos e Testes para o Participante M3

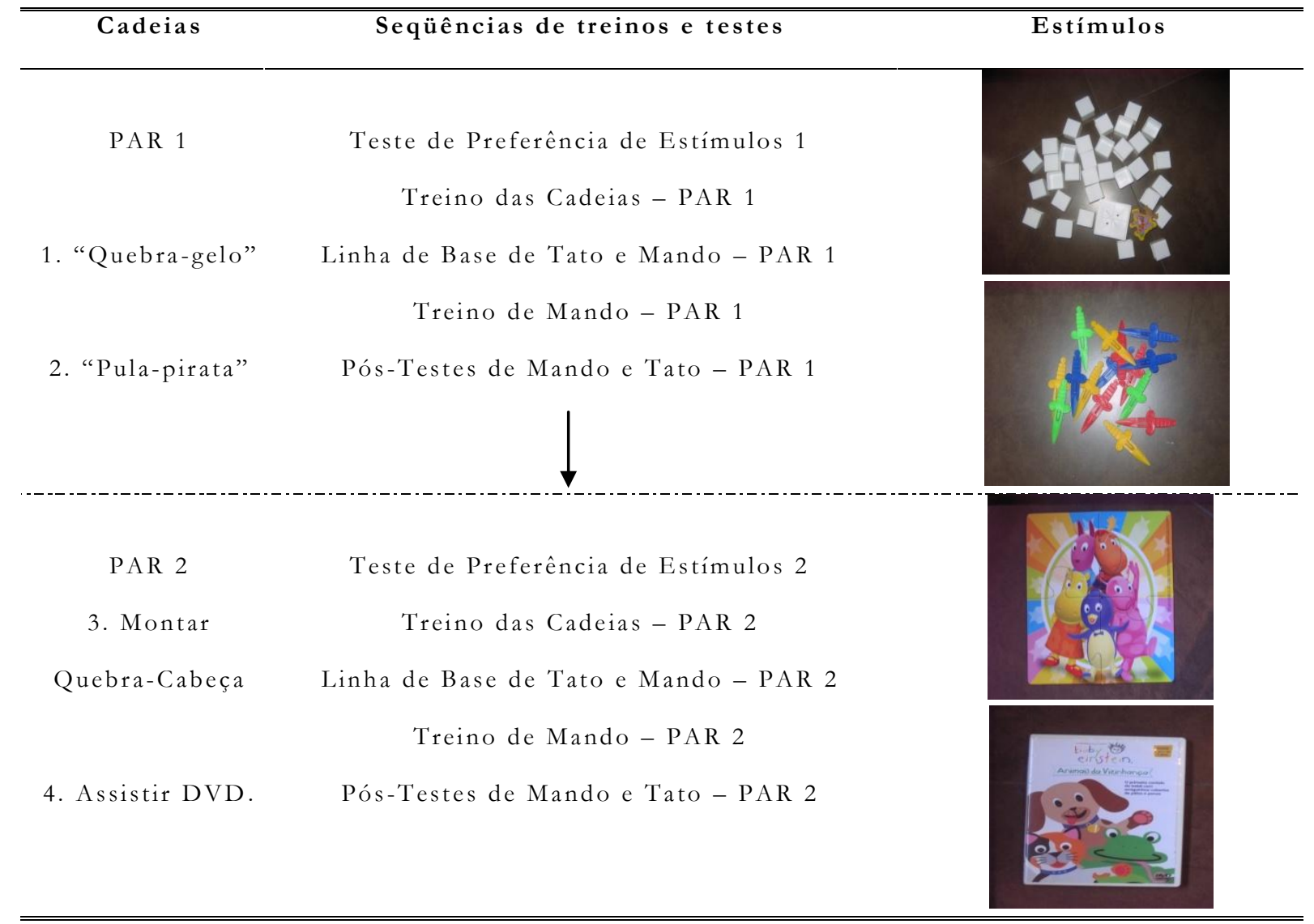

Os testes de mando e tato (Pré-Teste e Pós-Teste) realizados com M3 foram conduzidos conforme descrito na sessão Método Geral, assim como o Treino de Mando. No entanto, este último, por sua vez, apresentou uma particularidade: assim que o participante emitisse a resposta de selecionar a foto do item a ser pedido e a entregasse ao experimentador, este emitia a topografia 
da resposta vocalmente, ou seja, o experimentador nomeava a foto do item para o participante. Na Tabela 28 esquematizaram-se os estímulos envolvidos no Treino de Mando no Estudo 3, bem como os estímulos envolvidos na condição de teste de tato.

Essa nomeação ocorria da seguinte forma: o experimentador recebia a foto do item que estava sendo pedido pelo participante, segurava-a perto de sua boca e nomeava-a, pausadamente.

Uma vez emitida a resposta vocal pelo experimentador, o participante recebia o item pedido, independente de ter emitido ou não a resposta vocal, já que esta já havia sido previamente emitida. Em outras palavras, pode-se dizer que a emissão da resposta verbal vocal do experimentador era pareada com a entrega do estímulo de seleção. O participante não precisava emitir o ecóico para receber o item. As respostas verbais vocais emitidas por M3 no Treino de Mando foram registradas nas folhas de registros apropriadas (Anexo 8).

\section{TABELA 27}

Esquema dos Operantes Tato (na condição de Teste) e Mando (na condição de Treino)

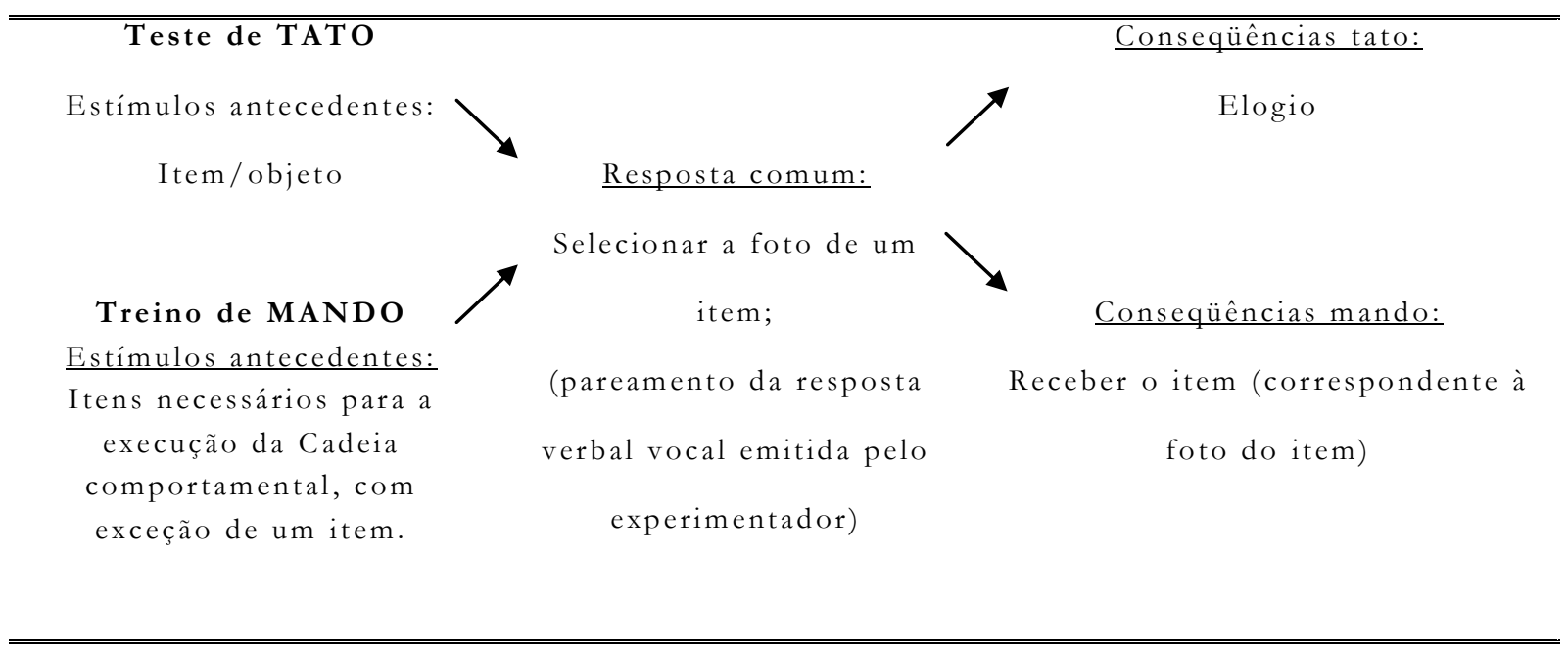


Resultados e Discussão

O Participante M3 precisou de três treinos de cadeia comportamental para atingir o critério de aprendizagem na tarefa, tanto para colocar espadas no barril e ver o pirata pular, quanto montar jogo quebra-gelo e martelar. Para atingir o critério de aprendizagem nas cadeias comportamentais para montar quebra-cabeça e ligar DVD e assistir sentado, M3 também precisou de três treinos para cada uma das cadeias.

Na Figura 11 é apresentado o desempenho do participante M3 no Treino de Mando. Em cada um dos gráficos de freqüência acumulada, existem duas curvas; uma referente às respostas baseadas na seleção de estímulos e a outra, referente às respostas emitidas pelo participante baseadas na topografia (respostas verbais vocais). Ainda, nos gráficos de freqüência acumulada, podem ser observados os acertos acumulados pelo participante nos treino. Os pontos cheios representam acertos com dica de respostas e os pontos vazios representam os acertos sem dica de resposta, ou seja, independentes, para cada item treinado. Nos histogramas, é apresentado o número total de acertos com dica, acertos independentes e o número de erros emitidos pelo participante M3 no treino de respostas baseadas na seleção de estímulos.

Os dados apresentados na Figura 11 indicam que o treino foi efetivo para que M3 emitisse mandos com as quatro topografias, tanto com respostas verbais baseadas na seleção de estímulos, quanto com respostas verbais vocais. Observou-se um aumento na freqüencia de emissões de mandos vocais para todos os itens treinados; já no início do treino dos itens gelo e espada, observouse a emissão de respostas vocais e ao final do treino dos itens quebra-cabeça $e$ DVD, quando as respostas baseadas na seleção começaram a ser emitidas independentemente. 
No treino do segundo par de estímulos, observa-se uma diminuição no número de tentativas necessárias para que o participante atingisse o critério de aprendizagem na tarefa. Para que M3 atingisse o critério de aprendizagem no treino do primeiro par de estímulos, foram necessárias 28 tentativas de treino, sendo que para o segundo par de itens treinados foram necessárias 16 tentativas. Esse dado nos permite hipotetizar que o fenômeno de learning set (também apresentado e discutido para o participante T1) pode ter ocorrido após o treino do primeiro par de estímulos treinados em mando.

Por fim, na Figura 11, observa-se que os acertos com dicas preponderaram no treino, seguido de acertos independentes (que sempre ocorreram na seqüência final das tentativas de treino: nas cinco últimas tentativas do treino do item gelo; nas oito últimas do item espada, com exceção da antepenúltima tentativa; nas seis últimas do item quebra-cabeça, com exceção da $12^{a}$; e nas quatro últimas tentativas do item $D V D$ ) e ocorreram erros para todos os itens treinados (três erros no treino do estímulo gelo, seis erros no estímulo espada, um erro no estímulo quebracabeça e dois erros no estímulo DVD). Os erros emitidos por M3 representam momentos nos quais o participante jogava contra o chão as fotos dos itens e levantava-se da mesa. 

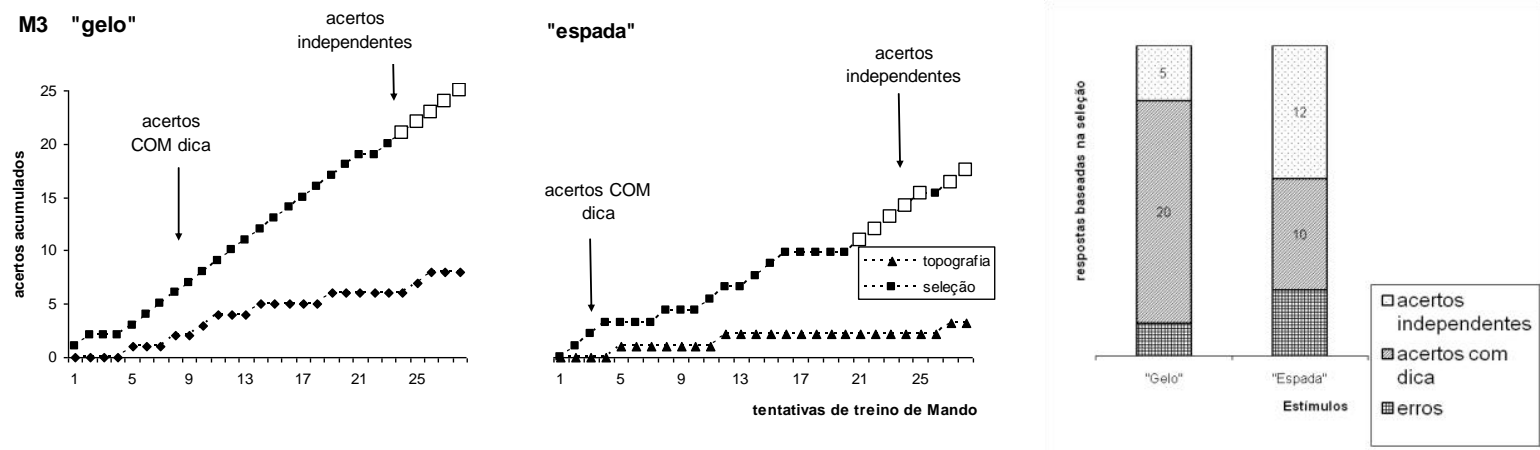

"quebra-cabeça"

"DVD"
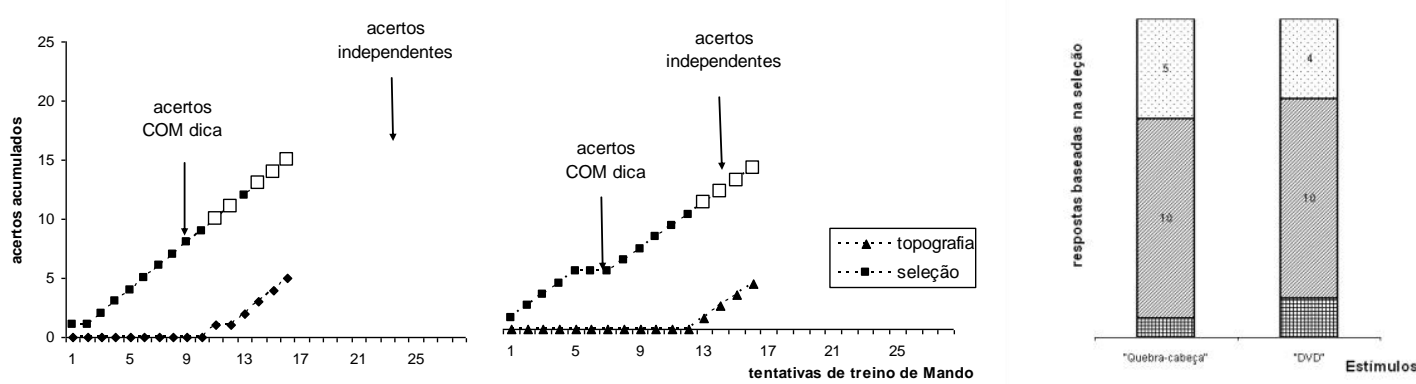

Figura 11. Desempenho do participante M3 nos Treinos de Mando para os itens gelo, espada, quebra-cabeça e DVD.

Na Figura 12, é apresentado o desempenho do participante M3 no PréTeste e Pós-Teste. Observa-se que M3 não emitiu respostas corretas nas tentativas de Pré-Teste de Mando e Tato, tanto para o primeiro par quanto para o segundo par. Nas tentativas de Pós-Teste, observa-se que todas as respostas testadas em mando (operante treinado) foram emitidas corretamente para todos os estímulos, em ambas as topografias de respostas (respostas baseadas na seleção de estímulos e respostas baseadas na topografia de estímulos). Isso ocorreu, provavelmente, porque as respostas verbais baseadas na seleção de estímulos, até então reforçadas no treino, passaram a não produzir mais o item reforçador específico, produzindo uma variabilidade no responder do participante; a variabilidade parece ter ido na direção do modelo vocal emitido pelo experimentador (e algumas vezes pelo próprio participante) nas tentativas de treino. 
Nas tentativas de Pós-Teste de Tato, observa-se a emissão de tato com respostas de seleção e com respostas vocais, sendo que a maior freqüência de emissões de tato foi para respostas vocais: duas emissões de tatos vocais para o item gelo e nas demais tentativas de teste dos outros três itens, M3 emitiu tatos vocais. Nas quatro tentativas de teste de tato do item quebra-cabeça, por exemplo, o participante não selecionou nenhuma foto, mas verbalizou sempre o nome do item apresentado.
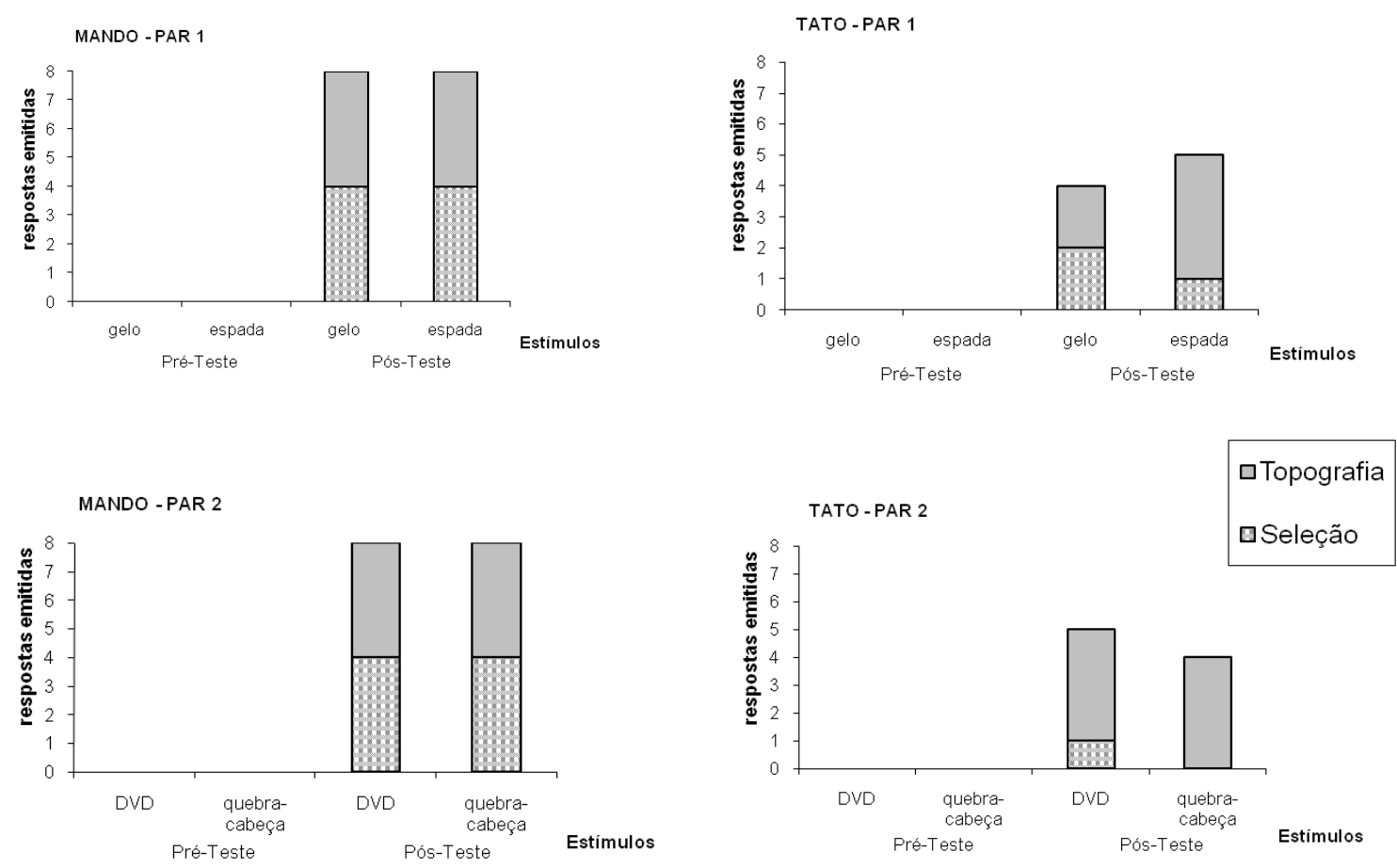

Figura 12. Número de respostas (baseadas na seleção de estímulos e vocais) emitidas por M3 nos testes, para os itens gelo, espada, quebra-cabeça e DVD.

Os dados acima descritos corroboram os achados já levantados por Charlop-Christy, Carpenter e LeBlanc (2002) de que ensino de topografias verbais com o respostas verbais baseadas na seleção de estímulos(ou PECS), concomitante à apresentação da emissão da topografia verbal vocal (disponibilizada pelo experimentador) parece favorecer o desenvolvimento de 
respostas verbais vocais. Além disso, o pareamento da resposta vocal parece ter favorecido a emissão das topografias de respostas vocais na condição de tato (operante não diretamente treinado), no Pós-Teste.

Deve-se considerar, ainda, que o repertório comportamental do participante M3, conforme os dados provindos da Avaliação de Linguagem de Sundberg e Partington (1998), aponta um desenvolvimento do repertório ecóico já fortalecido. Os operantes tato, mando e intraverbal, ainda estavam em desenvolvimento no repertório do participante, embora fossem emitidos com alguma freqüência e variabilidade. Assim, M3 pareceu ser um participante que apresentava pré-requisitos comportamentais necessários para o desenvolvimento da topografia de resposta verbal vocal, a partir do procedimento de ensino conforme descrito no Estudo 3. 


\section{Discussão Geral}

Esta pesquisa teve como objetivo estudar as relações funcionais entre os operantes tato e mando com topografia de respostas baseadas na seleção de estímulos. Tendo em vista a independência funcional entre os operantes tato e mando com respostas verbais vocais e com respostas verbais emitidas na linguagem de sinais, previamente identificada por Lamarre e Holland (1985), Hall e Sundberg (1987) e Twyman (1996), procuramos identificar se a independência funcional entre os operantes verbais tato e mando também poderia ser entendida para respostas verbais baseadas na seleção de estímulos, dando continuidade, de uma certa maneira, à pesquisa desenvolvida por Ziomek e Rehfeldt, 2008.

Michael (1985) diferenciou o comportamento verbal vocal ou gestual do comportamento verbal de respostas baseadas na seleção de estímulos. As respostas verbais vocais ou em linguagem de sinais foram categorizadas por Michael (1985) como comportamento verbal baseado na topografia (topographybased verbal behavior) e, o comportamento verbal de selecionar fotos/estímulos visuais, como comportamento verbal baseado na seleção de estímulos (selectionbased verbal behavior).

Michael (1985) categorizou tais comportamentos de acordo com os controles de estímulos envolvidos em cada um deles. Na Tabela 29, diferenciamse os estímulos antecedentes envolvidos no comportamento verbal baseados na seleção dos estímulos envolvidos no comportamento verbal baseados na topografia. 
Conforme apresentado na Tabela 28, observa-se que os controles de estímulos envolvidos nas respostas verbais baseadas na seleção e na topografia são distintos, tanto em tato quanto em mando.

As respostas verbais baseadas na seleção de estímulos em tato envolvem estímulos de segunda ordem ou estímulos condicionais, enquanto o tato com respostas verbais baseadas na topografia envolvem controle de estímulos discriminativos. O primeiro requer que o participante responda sob controle de discriminações condicionais, enquanto o segundo, requer que o participante responda sob controle de discriminações simples.

No caso do mando, as respostas verbais baseadas na seleção são emitidas sob controle de operações estabelecedoras e estímulos discriminativos (foto), enquanto o mando de respostas verbais baseadas na topografia envolvem apenas operações estabelecedoras.

Com base nesta tese, nossa suposição era de que, embora tatos e mandos sejam repertórios verbais independentes, quando o participante T1 fosse ensinado a emitir tatos com respostas verbais baseadas na seleção de estímulos, o estímulo discriminativo em tato, também presente nos estímulos antecedentes de mando (ou seja, a presença da foto), poderia funcionar como um facilitador para a emissão de mandos não diretamente treinados. No entanto, tal fenômeno não ocorreu. A presença do estímulo discriminativo comum em tato e em mando não foi suficiente para levar T1 a emitir mandos com as mesmas topografias treinadas em tato. 
TABELA 28

Estímulos Antecedentes às Respostas Verbais Baseadas na Seleção e às Respostas Verbais Baseadas na Topografia, em Tato e em Mando

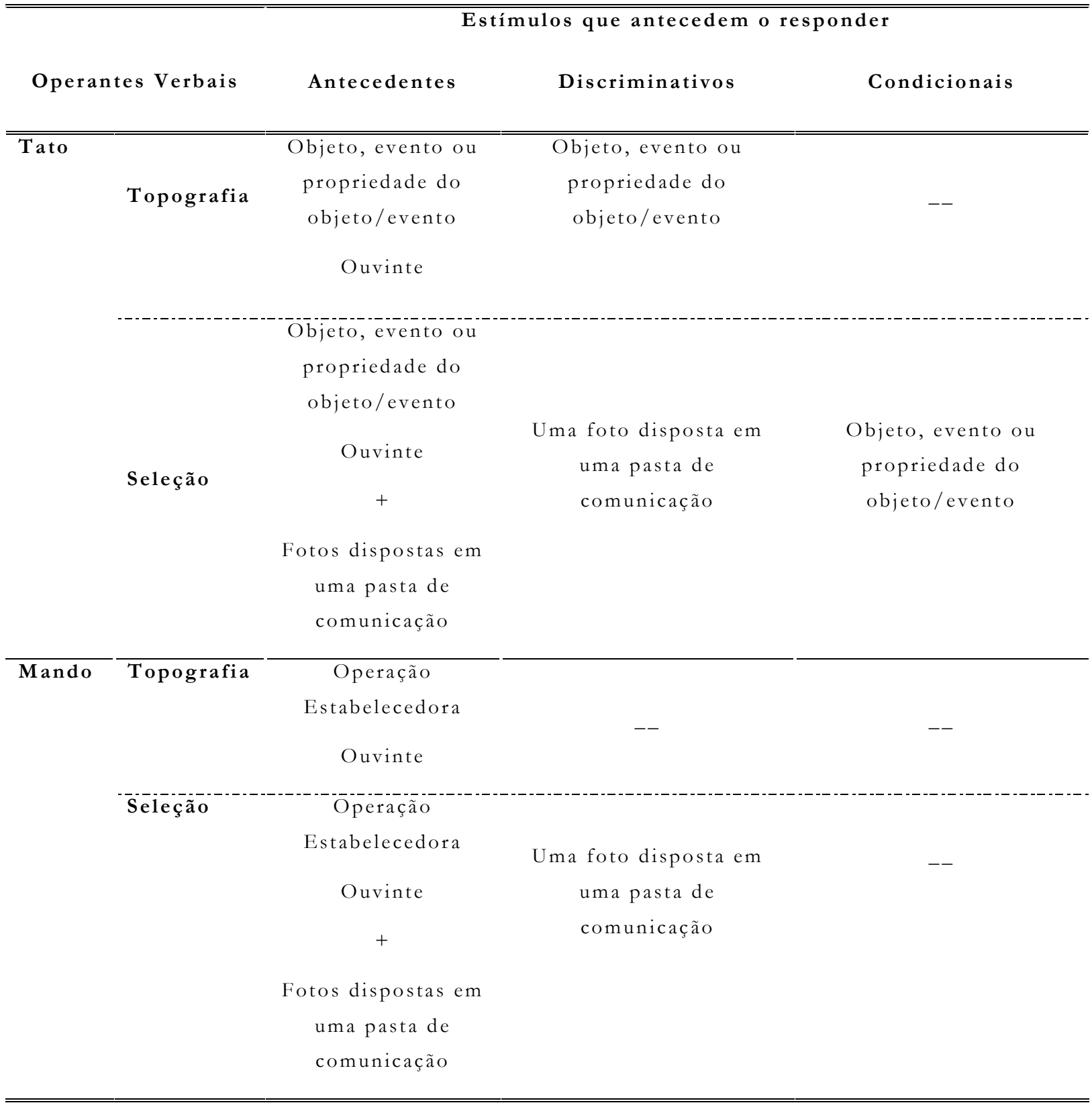

Na Tabela 29, diferencia-se o comportamento verbal de respostas baseadas na seleção do comportamento verbal baseado na topografia. Observa-se que enquanto nas respostas verbais baseadas na topografia, existe uma infinidade de variações topográficas; nas respostas verbais baseadas na seleção, apresenta-se apenas uma única topografia. Além disso, enquanto as respostas verbais baseadas 
na topografia envolvem discriminações simples, as respostas verbais baseadas na seleção envolvem discriminações condicionais. Supõe-se, por fim, que as respostas verbais vocais podem ser adquiridas mais facilmente que as respostas verbais baseadas na seleção por envolverem controle de estímulos menos complexos.

TABELA 29

Topografias das Respostas Verbais Baseadas na Seleção de Estímulos e das Respostas Verbais Baseadas na Topografia e seus respectivos Eventos Conseqüentes, nas Condições de Tato e Mando

\begin{tabular}{|c|c|c|}
\hline Operantes Verbais & Topografia & Estímulos conseqüentes \\
\hline \multirow{5}{*}{$\begin{array}{l}\text { Tato e } \\
\text { Mando }\end{array}$} & Vocal e variada & \\
\hline & Gestual e variada & \\
\hline & $\begin{array}{c}\text { Selecionar uma foto dentre } \\
\text { outros dois estímulos (uma } \\
\text { segunda foto e um cartão em } \\
\text { branco) }\end{array}$ & Reforço Generalizado em Tato \\
\hline & $\begin{array}{c}\text { Entregar a foto para o } \\
\text { ouvinte }\end{array}$ & Reforço específico em Mando \\
\hline & $\begin{array}{c}\text { Resposta é sempre a mesma, } \\
\text { o que muda é a foto } \\
\text { selecionada }\end{array}$ & \\
\hline
\end{tabular}

As diferenças de controle de estímulos bem como as diferenças topográficas entre as respostas verbais baseadas na topografia e na seleção não pareceram ser importantes para levar T1 a emitir respostas verbais previamente adquiridas em mando, no operante não diretamente treinado em tato. Esses dados foram apresentados no Estudo 1.

Diante dos dados do Estudo 1, procuramos identificar que variáveis poderiam ser facilitadoras na emissão de topografias verbais treinadas em uma 
determinada condição de estímulo (ou tato ou mando) sob controle de outra relação entre estímulos (se fora treinado em tato, emitido em mando e viceversa). Essas variáveis foram estudadas no Estudo 2. Tendo em vista que no estudo de Lamarre e Holland (1985), Hall e Sundberg (1987) e Twyman (1996) foram conduzidos treinos sob controle de estímulos antecedentes e conseqüentes múltiplos, neste estudo procuramos isolar o efeito dos conseqüentes múltiplos na emissão de um operante não diretamente treinado (reforço específico e elogios, para Mando e elogios e aquisição de um brinquedo, para tato).

Assim, ao treino de tato de respostas baseadas na seleção de estímulos adicionamos a apresentação de um reforçador condicionado (brinquedo) e um reforçador generalizado (elogios) à emissão de respostas em mando, configurando um Treino de Tato-Mando no primeiro caso e um Treino de Mando-Tato no segundo caso.

A manipulação dos conseqüentes em ambos os treinos pareceu ter sido facilitadora da emissão de respostas verbais no operante não diretamente treinado. Tal efeito foi observado a despeito do repertório comportamental dos participantes na ocasião do estudo: M2 era um participante com um maior déficit comportamental, quando comparado com os repertórios de M1 e T2 e, ainda assim, M2 emitiu o tato não diretamente treinado com topografias de respostas anteriormente treinadas em mando.

Por fim, buscamos identificar o efeito do pareamento da resposta verbal baseada na topografia (modelo vocal emitido pelo experimentador) no treino de topografias verbais baseadas na seleção de estímulos em mando e na emissão do tato (operante não diretamente treinado). Os resultados obtidos com o Estudo 3 indicaram que, além do participante M3 emitir respostas no operante não 
diretamente treinado, o mesmo passou a emitir respostas verbais baseadas na topografia, ou seja, M3 emitiu mandos e tatos vocais. Esse resultado replicou os achados do estudo de Charlop-Christy, Carpenter, Le, LeBlanc e Kellet (2002).

As análises até aqui descritas elucidam alguns pontos importantes em relação ao desenvolvimento de respostas verbais em crianças com atraso de linguagem ou diagnosticadas com autismo. Todos os participantes do estudo emitiram novas topografias verbais em tato e em mando com o uso de fotos, topografias estas tanto treinadas diretamente, quanto indiretamente. Além disso, as respostas verbais vocais, emitidas pelo participante M3, sugerem que o treino de mando de respostas baseadas na seleção pode ser um facilitador para a emissão de respostas verbais baseadas na topografia, quando acrescentado o pareamento de respostas verbais vocais emitidas pelo experimentador.

Os procedimentos utilizados nos Treinos de Mando e Tato (Interrupção de Cadeia e Escolha de Acordo com o Modelo) foram efetivos para ensinar aos participantes a emitirem os operantes verbais previamente definidos. O procedimento de Treino de Tato foi suficiente para levar T1 e T2 a emitir tatos de maneira consistente. O procedimento de Interrupção de Cadeia, utilizado no Treino de Mando, também mostrou ser efetivo para que os participantes M1, M2 e M3 emitissem respostas verbais baseadas na seleção de estímulos sob controle de operações estabelecedoras condicionadas.

Em relação ao desenvolvimento das cadeias comportamentais que foram ensinadas aos participantes da pesquisa, não conseguimos desenvolver cadeias com tarefas comparáveis nem intra-participante e nem entre participantes; tampouco pôde-se uniformizar a posição do estímulo a ser treinado/testado (item ausente). Nossa proposta foi a de atender a diversidade de interesses e 
preferências sugeridas no Teste de Preferência de Estímulos (DeLeon \& Iwata, 1996). Apesar dessas variáveis não terem sido controladas no presente estudo, o desempenho dos participantes nos treinos e testes não parece ter sido influenciado por tais variáveis, já que não ocorreram diferenças significativas na aquisição (ou emissão) das diferentes topografias com um mesmo participante.

Dados de observação de sessão, no entanto, sugerem que o procedimento de Interrupção de Cadeia foi difícil de ser conduzido, de maneira geral, com os participantes. As cadeias comportamentais foram delineadas a partir do Teste de Preferência de Estímulos. As topografias de respostas treinadas (ou testadas) em mando dependiam do engajamento do participante na cadeia comportamental. Quando os itens necessários para a execução da cadeia comportamental eram dispostos à mesa, o participante se engajava (ou não) na primeira tarefa da cadeia. Quando o participante não o fazia, o Treino (ou Teste) de Mando não era possível de ser conduzido, já que as operações estabelecedoras não estariam controlando o responder dos participantes. Em alguns momentos, os experimentadores não podiam coletar os dados da pesquisa ou os coletava com poucas tentativas por sessão experimental. O acréscimo do reforço generalizado no Estudo 2 às respostas emitidas em mando pareceu minimizar o efeito temporário dos reforçadores condicionados (brinquedos) com as crianças do Estudo 2 .

O Treino de Tato, por sua vez, também foi de difícil condução, por se tratar de crianças com baixa sensibilidade a reforçadores sociais (ou generalizados). Assim, no Estudo 2, precisamos recorrer ao uso de reforçadores condicionados (brinquedos), selecionados a cada sessão, para manter o participante T2 sentado à mesa. A decisão tomada foi importante, pois favoreceu que o repertório de tato fosse adquirido prontamente por T2 e, ainda, pareceu 
favorecer a emissão do operante não diretamente treinado. T1, que não foi exposto a uma condição de treino de tato com o uso de reforçadores condicionados (brinquedos), precisou de mais tentativas de treino para adquirir as topografias de tato em questão.

A análise aqui apresentada não pretende esgotar a complexidade da compreensão e do ensino de relações verbais. Apenas ilustra algumas possibilidades de aplicação, investigação e interpretação do comportamento verbal à luz dos princípios de B. F. Skinner (1957), no relevante e desafiante contexto de ensino a crianças com déficits comportamentais importantes. 


\section{REFERÊNCIAS BIBLIOGRÁFICAS}

Alves, C., \& Ribeiro, A. F. (2007). Relações entre tatos e mandos durante a aquisição. Revista Brasileira de Terapia Comportamental e Cognitiva, Vol. IX, 2, 289-305.

Catania, C. (1999). Aprendizagem: Comportamento, Linguagem e Cognição. Artes Médicas, Porto Alegre, RS.

Charlop-Christy, M. H., Carpenter, M., Le, L., LeBlanc, L. A., \& Kellet, K. (2002). Using the Picture Exchange System (PECS) with children with autism: assessment of PECS acquisition, speech, social-communicative behavior, and problem behavior. Journal of the Applied Behavior Analysis, 35, $213-231$.

American Psychiatric Association. (1994). Diagnostic and Statistical Manual of Mental Disorders ( $4^{\text {th }}$ ed.). Washington, DC: Author.

De Leon, I. G. \& Iwata, B. (1996). Evaluation of multiple-stimulus presentation format for assessing reinforcer preferences. Journal of Applied Behavior Analysis, 29, 519-533.

Frost, L. A., \& Bondy, A. S. (1994). The Picture Exchange Communication System Training Manual. Cherry Hill, NJ: Pyramid Educational Consultants.

Hall, G., \& Sundberg, M. L. (1987). Teaching mands by manipulating conditioned establishing operations. The Analysis of Verbal Behavior, 5, 41 53. 
Keller, F. S., \& Schoenfeld, W. N.(1950/1996). Principles of Psychology: A Systematic Text in the Science of Behavior. New York: Appleton-CenturyCrofts.

Lamarre, J., \& Holland, J. G. (1985). The functional independence of mands and tacts. Journal of the Experimental Analysis of Behavior, 43, 5-19.

Matos, M. A. (1990). Controle experimental e controle estatístico: A filosofia do caso único na pesquisa comportamental. Ciência e Cultura, 42 (8), 585 592.

Michael, J. L. (1982). Skinner's elementary verbal relations: Some new categories. The Analysis of Verbal Behavior, 1, 1-3.

Michael, J. L. (1985). Two kinds of verbal behavior plus a possible third. The Analysis of Verbal Behavior, 3, 1-4.

Michael, J. (1993). Establishing Operations. The Behavior Analyst, 16, 191-206.

Sigafoos, J., Doss, S. \& Reichle, J. (1989). Developing Mand and Tact Repertories in persons with severe developmental disabilities using graphic symbols. Research in Developmental Disabilities, 10, 183-200.

Sigafoos, J., Reichle, J., Doss, S., Hall, K., \& Pettitt, L. (1990). "Spontaneous" transfer of stimulus control from tact to mand contingencies. Research in Developmental Disabilities, 11, 165-176.

Skinner, B. F. (1953). Science and Human Behavior. The Free Press, New York. Collier-Macmillan limited, London

Skinner, B. F. (1957/1992). Verbal Behavior. B.F. Skinner Foundation, Cambriged: Massachusetts. 
Sundberg, M. L \& Partington, J. W. (1998). Teaching Language to Children with Autism or other Developmental Disabilities. Pleasant Hill, CA: Behavior Analysts, Inc.

Twyman, J. S. (1996). The functional independence of impure mands and tacs of abstract stimulus properties. The Analysis of Verbal Behavior, 13, 1-19.

Wallace, M.D., Iwata, B. A., \& Hanley, G. P. (2006). Estabilishment of mands following tact training as a functional of the reinforcer strength.Journal of the Applied Bahavior Analysis, 39, 17-24.

Ziomek, M.M., \& Rehfeldt, R. A.( 2008). Investigating the acquisition, generalization, and emergence of untrained verbal operants for mands acquired using the picture exchange communication system in adults with severe developmental disabilities. The Analysis of Verbal Bebavior, 24, 15-30. 
ANEXO 1 
Estímulos e respostas envolvidas no teste de generalização de Sundberg e Partington (1987).

\begin{tabular}{|c|c|c|c|c|}
\hline & $\begin{array}{l}\text { Itens da cadeia } \\
\text { comportamental }\end{array}$ & $\begin{array}{l}\text { Respostas } \\
\text { Treinadas }\end{array}$ & $\begin{array}{c}\text { Respostas } \\
\text { testadas na } \\
\text { generalização }\end{array}$ & $\begin{array}{l}\text { Desempenho } \\
\text { nos testes de } \\
\text { generalização }\end{array}$ \\
\hline \multirow{6}{*}{ 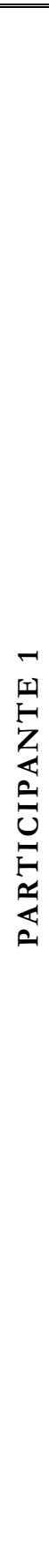 } & $\begin{array}{c}\text { Itens da cadeia de sopa, } \\
\text { com exceção da vasilha; } \\
\text { A instrução para iniciar a } \\
\text { cadeia era a mesma do } \\
\text { treino. }\end{array}$ & "água" & "vasilha" & $\varnothing$ \\
\hline & $\begin{array}{c}\text { Itens para cadeia de lata de } \\
\text { frutas, com exceça do } \\
\text { abridor de latas; } \\
\text { A instrução para iniciar a } \\
\text { cadeia era a mesma do } \\
\text { treino. }\end{array}$ & "lata" & "abridor de latas" & + \\
\hline & $\begin{array}{c}\text { Itens da cadeia de máquina } \\
\text { máquina diferente da } \\
\text { utilizada no treino; } \\
\text { A instrução para iniciar a } \\
\text { cadeia era a mesma do } \\
\text { treino. }\end{array}$ & "dinbeiro" & "dinbeiro" & + \\
\hline & $\begin{array}{c}\text { Itens da cadeia de secar a } \\
\text { mesa, sendo a mesa } \\
\text { diferente da utilizada no } \\
\text { treino; } \\
\text { A instrução para iniciar a } \\
\text { cadeia era a mesma do } \\
\text { treino. }\end{array}$ & "papel toalha" & "papel toalha" & + \\
\hline & $\begin{array}{c}\text { Cão treinada). Itens } \\
\text { utilizados era a coca-cola e } \\
\text { xícara. } \\
\text { A instrução emitida pelo } \\
\text { experimentador era "Beba } \\
\text { coca. Comece". }\end{array}$ & --- & "xícara" & + \\
\hline & $\begin{array}{c}\text { Mesa sem itens; } \\
\text { Sem instrução verbal } \\
\text { emitida pelo } \\
\text { experimentador; } \\
\text { Período após a sessão } \\
\text { experimental. }\end{array}$ & $\begin{array}{l}\text { "sopa", "agua", } \\
\text { "vasilha", } \\
\text { "colber", } \\
\text { "lata", } \\
\text { "abridor de } \\
\text { latas", "papel } \\
\text { toalha", } \\
\text { "dinbeiro", } \\
\text { "caminhar", } \\
\text { "correr", } \\
\text { "sentar"e } \\
\text { "comer". }\end{array}$ & $\begin{array}{l}\text { "sopa", "água", } \\
\text { "vasilba", } \\
\text { "colber", "lata", } \\
\text { "abridor de, } \\
\text { latas", "papel } \\
\text { toalha", } \\
\text { "dinbeiro", } \\
\text { "caminhar", } \\
\text { "correr", "sentar", } \\
\text { e "comer". }\end{array}$ & + , para todos \\
\hline
\end{tabular}


Estímulos e respostas envolvidas no teste de generalização de Sundberg e Partington (1987), cont.

\begin{tabular}{|c|c|c|c|c|}
\hline & $\begin{array}{l}\text { Itens da cadeia } \\
\text { comportamental }\end{array}$ & $\begin{array}{l}\text { Respostas } \\
\text { Treinadas }\end{array}$ & $\begin{array}{c}\text { Respostas } \\
\text { testadas na } \\
\text { generalização }\end{array}$ & $\begin{array}{l}\text { Desempenho } \\
\text { nos testes de } \\
\text { generalização }\end{array}$ \\
\hline \multirow{4}{*}{ 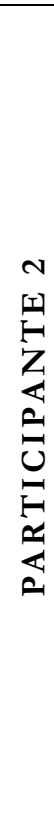 } & $\begin{array}{l}\text { Itens da cadeia de sopa, com } \\
\text { exceção da vasilha; } \\
\text { A instrução para iniciar a } \\
\text { cadeia era a mesma do treino. }\end{array}$ & "água" & "vasilha" & + \\
\hline & $\begin{array}{c}\text { Itens para a cadeia do ca fé } \\
\text { instantâneo, com exceção do } \\
\text { café; } \\
\text { cadeia era diferente da do } \\
\text { treino. }\end{array}$ & "xicara" & "café" & $\varnothing$ \\
\hline & $\begin{array}{l}\text { Itens da cadeia de lata de } \\
\text { frutas, com exceção da lata; } \\
\text { A instrução para iniciar a } \\
\text { cadeia era a mesma do treino. }\end{array}$ & $\begin{array}{l}\text { "abridor de } \\
\text { latas" }\end{array}$ & "lata" & + \\
\hline & $\begin{array}{c}\text { Itens da } \\
\text { figura; } \\
\text { A instrução para iniciar a } \\
\text { cadeia era diferente da do } \\
\text { treino. }\end{array}$ & "canetas" & "figura" & + \\
\hline
\end{tabular}

(o símbolo "Ø” sinaliza que o participante não emitiu a resposta testada na condição de generalização e o símbolo +, significa que o participante emitiu a resposta de Mando na condição de teste). 
ANEXO 2 
Autista, Transtorno.

F84.0 - 299.00 TRANSTORNO AUTISTA - DSM.IV

\section{Características Diagnósticas}

As características essenciais do Transtorno Autista são a presença de um desenvolvimento acentuadamente anormal ou prejudicado na interação social e comunicação e um repertório marcantemente restrito de atividades e interesses. As manifestações do transtorno variam imensamente, dependendo do nível de desenvolvimento e idade cronológica do indivíduo.

O Transtorno Autista é chamado, ocasionalmente, de autismo infantil precoce, autismo da infância ou autismo de Kanner. O prejuízo na interação social recíproca é amplo e persistente. Pode haver um prejuízo marcante no uso de múltiplos comportamentos nãoverbais (por ex., contato visual direto, expressão facial, posturas e gestos corporais) que regulam a interação social e a comunicação.

Pode haver um fracasso em desenvolver relacionamentos com seus pares que sejam apropriados ao nível de desenvolvimento, os quais assumem diferentes formas, em diferentes idades.

Os indivíduos mais jovens podem demonstrar pouco ou nenhum interesse pelo estabelecimento de amizades; os mais velhos podem ter interesse por amizades, mas não compreendem as convenções da interação social. Pode ocorrer uma falta de busca espontânea pelo prazer compartilhado, interesses ou realizações com outras pessoas (por ex., não mostrar, trazer ou apontar para objetos que consideram interessantes).

Uma falta de reciprocidade social ou emocional pode estar presente (por ex., não participa ativamente de jogos ou brincadeiras sociais simples, preferindo atividades solitárias, ou envolve os outros em atividades apenas como instrumentos ou auxílios "mecânicos"). Freqüentemente, a conscientização da existência dos outros pelo indivíduo encontra-se bastante prejudicada.

Os indivíduos com este transtorno podem ignorar as outras crianças (incluindo os irmãos), podem não ter idéia das necessidades dos outros, ou não perceber o sofrimento de outra pessoa.

O prejuízo na comunicação também é marcante e persistente, afetando as habilidades tanto verbais quanto não-verbais. Pode haver atraso ou falta total de desenvolvimento da linguagem falada. Em indivíduos que chegam a falar, pode existir um acentuado prejuízo na capacidade de iniciar ou manter uma conversação, um uso estereotipado e repetitivo da linguagem ou uma linguagem idiossincrática.

Além disso, podem estar ausentes os jogos variados e espontâneos de faz-de-conta ou de imitação social apropriados ao nível de desenvolvimento. Quando a fala chega a se desenvolver, o timbre, a entonação, a velocidade, o ritmo ou a ênfase podem ser anormais (por ex., o tom de voz pode ser monótono ou elevar-se de modo interrogativo ao final de frases afirmativas). 
As estruturas gramaticais são freqüentemente imaturas e incluem o uso estereotipado e repetitivo da linguagem (por ex., repetição de palavras ou frases, independentemente do significado; repetição de comerciais) ou uma linguagem metafórica (isto é, uma linguagem que apenas pode ser entendida claramente pelas pessoas familiarizadas com o estilo de comunicação do indivíduo).

Uma perturbação na compreensão da linguagem pode ser evidenciada por uma incapacidade de entender perguntas, orientações ou piadas simples. As brincadeiras imaginativas em geral estão ausentes ou apresentam prejuízo acentuado. Esses indivíduos também tendem a não se envolver nos jogos de imitação ou rotinas simples da infância, ou fazem-no fora de contexto ou de um modo mecânico.

Os indivíduos com Transtorno Autista têm padrões restritos, repetitivos e estereotipados de comportamento, interesses e atividades. Pode existir uma preocupação total com um ou mais padrões estereotipados e restritos de interesse, anormais em intensidade ou foco; uma adesão aparentemente inflexível a rotinas ou rituais específicos e não funcionais; maneirismos motores estereotipados e repetitivos; ou uma preocupação persistente com partes de objetos.

Os indivíduos com Transtorno Autista apresentam uma faixa acentuadamente restrita de interesses e com freqüência se preocupam com um interesse limitado (por ex., com acumular fatos sobre carros ou aviões).

Eles podem enfileirar um número exato de brinquedos da mesma maneira repetidas vezes ou imitar vezes sem conta as ações de um ator de televisão. Podem insistir na mesmice e manifestar resistência ou sofrimento frente a mudanças pouco importantes (por exemplo, a mudança do local no qual sempre era colocada uma dada mesa de centro).

Existe um interesse por rotinas ou rituais não-funcionais ou uma insistência irracional em seguir rotinas (por exemplo, percorrer exatamente o mesmo caminho para a escola, todos os dias). Os movimentos corporais estereotipados envolvem as mãos (bater palmas, estalar os dedos) ou todo o corpo (balançar-se, inclinar-se abruptamente ou oscilar o corpo). Anormalidades da postura (por ex., caminhar na ponta dos pés, movimentos estranhos das mãos e posturas corporais) podem estar presentes.

Esses indivíduos apresentam uma preocupação persistente com partes de objetos (botões, partes do corpo). Também pode haver uma fascinação com o movimento em geral (por ex., as rodinhas dos brinquedos em movimento, o abrir e fechar de portas, ventiladores ou outros objetos com movimento giratório rápido). O indivíduo pode apegar-se intensamente a algum objeto inanimado (por ex., um pedaço de barbante ou uma faixa elástica).

A perturbação deve ser manifestada por atrasos ou funcionamento anormal em pelo menos uma das seguintes áreas antes dos 3 anos de idade: interação social, linguagem usada para a comunicação social, ou jogos simbólicos ou imaginativos (Critério B). Não existe, em geral, um período de desenvolvimento inequivocadamente normal, embora 1 ou 2 anos de desenvolvimento relativamente normal sejam relatados em alguns exemplos. 
ANEXO 3 


\section{TERMO DE CONSENTIMENTO LIVRE E ESCLARECIDO}

São Paulo,

Senhores pais ou responsáveis,

Sou aluna do curso de Doutorado em Psicologia Experimental da USP e estou estudando em minha tese questões relacionadas à linguagem de crianças com desenvolvimento atípico.

Basicamente, trata-se de um estudo que tentará identificar possíveis diferenças entre a aquisição da linguagem com o uso de fotos e a aquisição da linguagem comum (vocal ou falada).

A pesquisa pretende ensinar à criança a emitir pedidos ou nomear objetos com o uso de fotos. Cada criança será estudada e treinada, individualmente. Durante a pesquisa a criança receberá algumas guloseimas (biscoitos, balas, chocolates etc) e/ou terá acesso a um (a) brinquedo/ brincadeira que goste, como prêmio por ter participado do trabalho.

As sessões de ensino ocorrerão após o encerramento das sessões de Terapia Comportamental ou após a aula de Educação Física e deverá durar, em média, 20 minutos.

É permitido aos senhores encerrar a participação de seu/sua filho (a) na pesquisa a qualquer momento, caso julguem necessário.

Os resultados deste trabalho serão acadêmicos e serão divulgados único e exclusivamente para este fim, sendo garantido o sigilo da identidade de todos os participantes deste trabalho.

Em alguns momentos precisarei entrar em contato com vocês para me informar sobre a rotina de seu filho (a), suas atividades preferidas, suas guloseimas preferidas etc.

Caso os senhores queiram me conhecer, ou esclarecer alguma dúvida sobre a pesquisa, coloco-me a inteira disposição.

Atenciosamente,

Cíntia Guilhardi

Concordo que meu/minha filho (a) participe da pesquisa referida acima, 
ANEXO 4 


\section{Caracterização do repertório verbal dos participantes: Avaliação de linguagem (Sundberg \& Partington, 1998)}

\section{Mando: refere-se repertório de emitir pedidos.}

\section{(Sundberg \& Partington, 1998)}

ESCORE 1: Não emite mandos (não emite qualquer sinalização quando com sede, fome ou necessitando de algo) e geralmente engaja-se em comportamentos disruptivos. O aprendiz também pode adquirir o item desejado sem a mediação de um ouvinte ou o próprio ambiente social disponibiliza itens (comidas, bebidas, brinquedos) de tempos em tempos, não criando uma condição para o aprendiz emitir mandos para a obtenção dos mesmos.

ESCORE 2: Puxa as pessoas, aponta para itens ou posiciona-se na frente de itens reforçadores. Essas topografias motoras também acabam tendo uma função comunicativa de mando, uma vez que possibilitam que o adulto disponibilize os itens desejados pelo aprendiz. Os mandos são emitidos, normalmente, algumas vezes ao dia.

ESCORE 3: Emite de um a cinco mandos para itens reforçadores com o uso de palavras, sinais ou figuras. Normalmente os itens reforçadores envolvem atividades, alimentos e bebidas; e os mandos podem ser emitidos com dicas de respostas provindas por um adulto.

ESCORE 4: Emite de cinco a dez mandos para itens reforçadores, com o uso de palavras, sinais ou figuras.O aprendiz emite os mandos com maior freqüências e aprende novas topografias de mando com mais facilidade, ou, em outras palavras, sem a necessidade de treinos repetitivos e sistemáticos.

ESCORE 5: Emite freqüentemente mais de dez mandos, através de palavras, fotos ou sinais. Normalmente os pedidos vêm acompanhados da frase "Eu quero".

2. Tato: refere-se ao repertório de nomear itens (objetos ou propriedades dos objetos) e ações.

\section{(Sundberg \& Partington, 1998)}

ESCORE 1: Não emite nenhum tato de itens (objeto, propriedade do objeto) ou de ação observada no ambiente. Geralmente, quando solicitado a emitir tatos, o aprendiz emite comportamentos disruptivos. 
ESCORE 2: Emite de um a cinco tatos de objetos ou ações, normalmente associados a objetos ou atividades com alto valor reforçador.

ESCORE 3: Emite de seis a 15 tatos de objetos ou ações, envolvendo objetos familiares ao aprendiz. As respostas de tato normalmente ocorrem com poucos erros e poucas dicas de respostas.

ESCORE 4: Emite de 16 a 50 tatos de objetos ou ações. O aprendiz é capaz de tatear diferentes tipos de objetos dentro de uma mesma categoria. Por exemplo, tateia diferentes tipos de carros. Além disso, emite tatos na presença de diferentes adultos, sem dicas de respostas ou emissão de comportamentos disruptivos.

ESCORE 5: Emite tatos de mais de 100 objetos, ações e frases. Normalmente, o aprendiz emite novos tatos de maneira rápida e sem a necessidade de treinos sucessivos para a aprendizagem dos mesmos.

\section{Vocal Play ${ }^{35}$ refere-se à emissão espontânea de sons ou palavras pelo aprendiz, comumente reconhecido como balbucio.}

\section{(Sundberg \& Partington, 1998)}

ESCORE 1: Não emite nenhum som.

ESCORE 2: Emite poucos sons (até cinco $^{36}$ ) semelhantes aos sons da língua materna, em baixa freqüência. Geralmente os sons ocorrem quando a criança se encontra envolvida ${ }^{37}$ ou é instruída para emissão do mesmo.

ESCORE 3: Emite muitos (de seis a 15) sons da língua materna e, algumas vezes, com entonações, volume e tons variados. É raro o reconhecimento de palavras nos sons emitidos pelo aprendiz.

\footnotetext{
35 A terminologia Vocal Play foi utilizada pelos autores para descrever a emissão espontânea de sons ou palavras pelo participante, comumente reconhecido como balbucio. Prefere-se a compreensão desse comportamento conforme proposto por Skinner (1957/1992): são sons emitidos pelo participante que são mantidos por auto-reforçamento (e não por uma comunidade verbal que disponibiliza o reforço). Ainda segundo Skinner (1957/1992), as respostas verbais mantidas por auto-reforçamento são produtos do processo de reforço condicionado, no qual certos padrões sonoros, por terem sido associados a eventos reforçadores, se transformam num reforçador condicionado (p.58). Nota-se que Skinner não se utiliza da nomenclatura vocal play, mas respostas mantidas por auto-reforçamento.

36 Os autores utilizam apenas a descrição de "poucos", "vários". Prefere-se uma indicação quantitativa, por isso, descreve-se neste trabalho, "até cinco" sons, para escore 2; de "seis a 15 " sons, para escore 3; "até cinco" palavras, para escore 4; e, por fim, "mais que 15" sons ou palavras, para escore 5 .

${ }^{37}$ Tradução do ingles excited.
} 
ESCORE 4: Emite sons identificáveis aos sons da língua materna, frequentemente. É possível reconhecer a emissão de poucas (até cinco) palavras. O aprendiz se engaja no vocal play quando está manipulando brinquedos.

ESCORE 5: Emite vários sons (mais que 15) semelhantes aos sons da língua materna e várias (mais que 15) palavras da língua materna.

\section{Ecóico: refere-se a habilidade de repetir sons e palavras emitidas por um outro.}

(Sundberg \& Partington, 1998).

ESCORE 1: Não repete nenhum som ou palavra emitido por outro membro da comunidade verbal, tão pouco emite vocal play. Normalmente engaja-se em comportamento disruptivo quando é solicitada a repetir sons/palavras.

ESCORE 2: Repete poucos (até cinco) ${ }^{38}$ sons ou palavras emitidas por outro. Para que as palavras ou sons sejam ecoados é necessário disponibilizar muitas dicas de respostas e disponibilizar itens com alto valor reforçador.

ESCORE 3: Repete (de maneira precisa - com correspondência ponto a ponto ao estímulo antecedente - ou de maneira aproximada) vários (de seis a 15) sons ou palavras da língua materna, sem a necessidade de dicas de respostas e sem a emissão de comportamentos disruptivos.

ESCORE 4: Repete de maneira precisa ou aproximada muitas (mais que 15) palavras da língua materna, sem a necessidade de dicas de respostas, sem a disponibilização de itens com alto valor reforçador; e sem a emissão de comportamentos disruptivos quando é solicitado a emitir o comportamento ecóico.

ESCORE 5: Repete claramente qualquer palavra e até frases simples da língua materna, que são ouvidas em seu ambiente natural.

\section{Intraverbal ${ }^{39}:$ refere-se ao repertório de responder questões verbais emitidas por outro ou continuar frases iniciadas por outros.}

\section{(Sundberg \& Partington, 1998)}

\footnotetext{
38 Os autores utilizam apenas a descrição de "poucos", "vários", "muitas". Prefere-se uma indicação quantitativa, por isso, descreve-se neste trabalho, "até cinco" ecóicos, para escore 2 ; de “seis a 15" ecóicos , para escore 3; “mais que 15” ecóicos para escore 4.

39 Segundo Skinner (1957/1992) o intraverbal é um comportamento sob controle de estímulos verbais, sendo que, a resposta verbal, não apresenta correspondência ponto a ponto com os estímulos que a evocam (p.71).
} 
ESCORE 1:Não continua frases iniciadas por outro falante, não responde a questões feitas por uma pessoa e não canta trechos de músicas.

ESCORE 2: Completa algumas frases emitidas por outros (por exemplo, diz "miau" quando um falante diz "o gato faz..."), principalmente quando a frase envolve estímulos reforçadores (frases de filmes reforçadores ou músicas reforçadoras, por exemplo).

ESCORE 3: Completa dez frases que não estão associadas a estímulos reforçadores ou responde a dez questões.

ESCORE 4: Completa 20 frases ou responde a 20 questões, com variação. ESCORE 5: Responde a pelo menos 30 questões com variação.

\section{Cooperação com adultos: refere-se ao seguimento de comandos provindos de um adulto. \\ (Sundberg \& Partington, 1998)}

ESCORE 1: Sempre não cooperativo, esquiva-se de trabalho e engaja-se em comportamentos disruptivos (ex. choro, berros, hetero-agressão, auto-lesão e destruição do ambiente).

ESCORE 2: Emite apenas uma resposta fácil e curta quando disponível um item com alto valor reforçador. Geralmente as respostas emitidas ocorrem após dicas fornecidas pelo experimentador.

ESCORE 3: Emite cinco respostas, sem apresentação de comportamentos disruptivos, quando disponíveis itens de alto valor reforçador a cada resposta.

ESCORE 4: O aprendiz mantém-se trabalhando por cinco minutos, sem a emissão de comportamentos disruptivos. No entanto, faz-se necessário um intervalo após permanecer por cinco minutos em atividade. A tarefa é facilmente retomada pelo aprendiz após os intervalos. Ainda, menos densidade de reforço é necessário para manter o aprendiz engajado nas tarefas.

ESCORE 5: O aprendiz mantém-se trabalhando por dez minutos, sem a apresentação de comportamentos disruptivos. Facilmente o aprendiz retoma a tarefa após os intervalos e menos densidade de reforço é necessário para mantêlo engajado nas tarefas. 
7. Imitação Motora: refere-se ao repertório de modelação, ou seja, emitir a mesma resposta de coordenação motora apresentada por um outro

\section{indivíduo (Sundberg \& Partington, 1998).}

ESCORE 1: Não imita nenhum movimento de coordenação motora emitido por outro.

ESCORE 2: Imita alguns movimentos de coordenação motora grossa (até cinco ${ }^{40}$ ) diante de um modelo. Por ex. corre, pula, bate palmas, ergue os braços quando outros emitem tais movimentos.

ESCORE 3:Imita vários (de seis a 15) movimentos de coordenação motora grossa diante de um modelo e quando solicitado para tanto.

ESCORE 4: Imita vários (de seis a 10) movimentos de coordenação motora grossa e fina, diante de um modelo, com poucas dicas de respostas provindas pelo experimentador/outro.

ESCORE 5: Imita movimentos de coordenação motora grossa ou fina facilmente (16 ou mais), geralmente sem dicas de respostas (espontaneamente).

8. Escolha de acordo com o modelo (MTS): refere-se ao repertório de emparelhar objetos ou figuras iguais entre si.

(Sundberg \& Partington, 1998)

ESCORE 1: Não emparelha quaisquer figuras/objeto iguais entre si.

ESCORE 2:Emparelha de um a dois objetos / figuras iguais entre si.

ESCORE 3: Emparelha de cinco a dez objetos/figuras iguais ente si

ESCORE 4: Emparelha de cinco a dez cores, formas ou figuras abstratas iguais entre si Além disso, é capaz de parear muitos objetos/figuras iguais entre si.

ESCORE 5: Emparelha incontáveis estímulos iguais entre si: objetos com figuras, figuras com desenhos e é capaz de emparelhar figuras que se combinam por sua função, característica ou classe.

\section{Repertório Receptivo $(R R)^{41}$ : refere-se ao repertório de comportar-se como um ouvinte perante instruções verbais.}

(Sundberg \& Partington, 1998)

\footnotetext{
40 Os autores utilizam apenas a descrição de "alguns", "vários" ou "facilmente". Prefere-se uma indicação quantitativa, por isso descreve-se, neste trabalho, "até cinco" movimentos, para escore 2; de "seis a 15" movimentos, para escore 3; de "seis a dez" movimentos, para escore 4; e, por fim, "mais que 15" movimentos, para escore 5.

${ }^{6}$ Mantém-se a terminologia proposta por Sundberg et al. (1998), embora seja mais apropriada a terminologia repertório de ouvinte, conforme proposto por Skinner (1957/1992).
} 
ESCORE 1: Não se comporta como um ouvinte diante qualquer instrução verbal ou palavra emitida por um falante. Por exemplo, instruções simples como "venha aqui", "levante-se" não evoca nenhuma resposta por parte do aprendiz. Normalmente, esses aprendizes apresentam comportamentos disruptivos.

ESCORE 2: Segue algumas (até cinco) ${ }^{42}$ instruções simples relacionadas às atividades da rotina, principalmente quando as mesmas vêm acompanhadas de outras dicas de respostas visuais. Por exemplo, ao escutar "pegue a sua lancheira" e visualizar seus pares pegando suas respectivas lancheiras, o aprendiz é capaz de seguir tal comando verbal.

ESCORE 3: Segue algumas (até cinco) instruções para fazer ações ou tocar itens independentes dos contextos aos quais as instruções são emitidas.

ESCORE 4: Segue muitas instruções e aponta para pelos menos 25 itens diante palavras ditadas pelo falante.

ESCORE 5: Aponta para pelo menos cem itens, ações, pessoas ou adjetivos.

\section{Repertório Receptivo por Função, Característica ou Classe (RFCC):} refere-se ao repertório de comportar-se como um ouvinte diante instruções verbais referentes a características, classe ou função dos objetos.

\section{(Sundberg \& Partington, 1998)}

ESCORE 1: Não comporta-se como um ouvinte a partir de informação sobre os objetos (função, característica ou classe).

ESCORE 2: Comporta-se como um ouvinte diante instruções sobre a função de alguns objetos.

ESCORE 3: Comporta-se como um ouvinte diante de até três comandos verbais sobre funções ou características de até dez itens.

ESCORE 4: Comporta-se como um ouvinte diante de até quatro comandos verbais sobre função, característica ou classe de 11 à 25 itens.

ESCORE 5: Comporta-se como um ouvinte diante de até cinco comandos verbais sobre a função, característica ou classe de pelo menos cem itens.

\section{Letras e Números: refere-se ao repertório de nomear ou identificar}

(repertório de ouvinte) letras ou números.

\footnotetext{
42 Os autores utilizam apenas a descrição de “algumas”. Prefere-se uma indicação quantitativa, por isso, descreve-se neste trabalho, "até cinco" instruções simples, para escore 2; e "até cinco" instruções para executar ações, para escore 3.
} 
(Sundberg \& Partington, 1998)

ESCORE 1: Diante de letras, números e/ou palavras escritas emite outras respostas, exceto a de nomeá-las adequadamente.

ESCORE 2: Identifica ou nomeia pelo menos três letras ou números.

ESCORE 3: Identifica ou nomeia pelo menos 15 letras ou números.

ESCORE 4: Identifica ou lê pelo menos cinco palavras e identifica ou nomeia pelo menos cinco números.

ESCORE 5: Identifica ou lê pelo menos 25 palavras e identifica ou nomeia dez números.

12. Interação Social: refere-se à interação verbal do aprendiz com um membro da comunidade verbal ou o quão próximo fisicamente o aprendiz permanece de seus pares ou outros.

(Sundberg \& Partington, 1998)

ESCORE 1: Não inicia qualquer interação social com outros, aparentando estar “desinteressado" nas pessoas. Mantém-se, na maior parte do tempo, isolado. Alguns aprendizes emitem comportamentos disruptivos quando é proposta alguma interação social.

ESCORE 2: Aproxima-se fisicamente de outro indivíduo para iniciar uma interação social, principalmente quando o outro lhe é familiar. Permanece brincando próximo de outras crianças, mas não compartilha o mesmo brinquedo ou brincadeira.

ESCORE 3: Prontamente pede aos adultos itens ou objetos reforçadores. Normalmente a interação é maior com adultos do que com seus pares (outras crianças)

ESCORE 4: Interage verbalmente com seus pares, com dicas de respostas provindas por um adulto (intermediação do adulto).

ESCORE 5: Frequentemente inicia e mantém uma interação social com seus pares, ou seja, fala e brinca com outras crianças sem a intermediação de um adulto. 
ANEXO 5 


\section{LANGUAGE ASSESSMENT FORM ${ }^{43}$}

(Sudberg \& Partington, 1998)

Name:

Assessor:

Date:

Location(s) of Assessment:

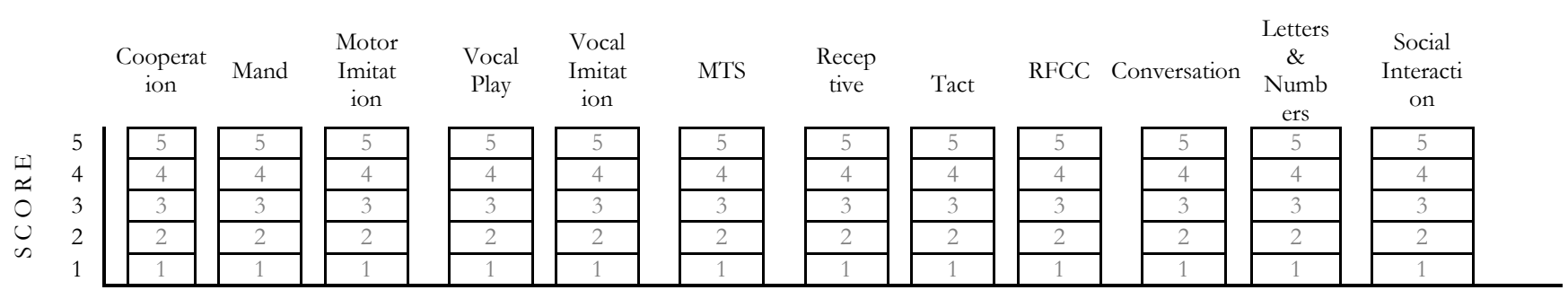

For the following questions, circle the level of performance that best describes the learner's typical level.

1. COOPERATION WITH ADULTS (i.e., how easy is it to work with the child?)

1. Always uncooperative, avoids work, engages in negative behavior

2. Will do only one brief and easy response for a powerful reinforcer

3. Will give at least 5 responses without negative behavior

4. Will work for at least 5 minutes without negative behavior

5. Will work for at least 10 minutes without negative behavior

2. REQUESTS (MANDS) (i.e., how does the learner let his/her needs and wants be known?)

1. Does not ask for reinforcing items or engages in negative behavior to obtain reinforcing items

2. Pulls people, points or stands by reinforcing items

3. Uses 1-5 words, signs, or pictures to ask for reinforcing items

4. Uses 5-10 words, signs, or pictures to ask for reinforcing items

5. Frequently requests reinforcing items using 10 or more words, signs or pictures

3. MOTOR IMITATION (i.e., does the learner copy actions of others?)

1. Does not imitate anybody's motor movements

2. Imitates a few gross motor movements modeled by others

3. Imitates several gross motor movements upon request

4. Imitates several fine and gross motor movements upon request

5. Easily imitates any fine or gross motor movements, often spontaneously

4. VOCAL PLAY (i.e., does the learner spontaneously say sounds and words?)

1. Does not make any sounds (mute)

2. Makes a few speech sounds at a low rate

3. Vocalizes many speech sounds with varied intonations

4. Vocalizes frequently with varied intonation and says a few words

5. Vocalizes frequently and says many clearly understandable words

5. VOCAL IMITATION (ECHOIC) (i.e., will the learner repeat sounds or words?)

1. Does not repeat any sounds or words

2. Will repeat a few specific sounds or words

${ }^{43}$ Formulário adaptado de Sundberg e Partington, 1998. 
3. Will repeat or closely approximate several sounds or words

4. Will repeat or closely approximate many different words

5. Will clearly repeat any word or even simple phrases

6. MATCHING-TO-SAMPLE (i.e., will the learner mach objects, pictures and designs to presented samples?)

1. Does not match any objects or pictures to a sample

2. Will match 1 or 2 objects or pictures to a sample

3. Will match 5 to 10 objects or pictures to a sample

4. Will match 5 to 10 colors, shapes or designs to a sample

5. Will match most items and match 2 to 4 block designs

7. RECEPTIVE (i.e., does the learner understand any words or follow directions?)

1. Does not understand any words

2. Will follow a few instructions related to daily routines

3. Will follow a few instructions and do actions or touch items

4. Will follow many instructions and point to at least 25 items

5. Will point to at least 100 items, actions, persons or adjectives

8. LABELING (TACTS) (i.e., does the learner label or verbally identify any items or actions?)

1. Does not identify any items or actions

2. Will identify 1 to 5 items or actions

3. Will identify $6-15$ items or actions

4. Will identify $16-50$ items or actions

5. Will identify more than 50 items or actions and emits short sentences

9. RECEPTIVE BY FEATURE, FUNCTION AND CLASS (i.e., does the learner identify items when given information about those items?)

1. Does not identify items based upon information about them

2. Will identify a few items given synonyms or common features

3. Will identify 10 items given 1 to 3 features, functions or classes

4. Will identify 25 items given 4 features, functions or classes

5. Will identify 100 items given 5 features, functions or classes

10. CONVERSATIONAL SKILLS (INTRAVERBALS) (i.e., does the learner fill-in missing words or answer questions?)

1. Does not fill-in missing words or parts of songs

2. Will fill-in a few missing words or provide animal sounds

3. Will fill-in 10 non-reinforcing phrases or answer at least 10 simple questions

4. Will fill-in 20 phrases or answer 20 questions with variation

5. Will answer at least 30 questions with variation 
11. LETTERS AND NUBERS (i.e., does the learner know any letters, numbers or written words?)

1. Does not identify any letters, number or written words

2. Will identify at least 3 letters or numbers

3. Will identify at least 15 letters or numbers

4. Will read at least 5 words and identify 5 numbers

5. Will read at least 25 words and identify 10 numbers

12. SOCIAL INTERACTION (does the learner initiate and sustain interactions with others?)

1. Does not initiate interactions with others

2. Physically approaches others to initiate an interaction

3. Readily asks adults for reinforcers

4. Verbally interacts with peers and prompts

5. Regularly initiations and sustains verbal interactions with peers

Comments: 
ANEXO 6 


\section{Folha de Registro da Avaliação de Preferência com Múltiplos Estímulos}

(adaptada de DeLeon \& Iwata, 1996)

\section{Participante:}

Experimentador:

Data:

\section{Itens:}

1.

2 .

3.

4.

5.

6.

7.

\begin{tabular}{|lcc|c|}
\hline \multicolumn{3}{|c|}{ Circule p posição } & Item selecionado \\
\hline 1. & $\mathrm{x} \times \mathrm{x} \times \mathrm{x} \times \mathrm{x}$ & \\
\hline 2. & $\mathrm{x} \times \mathrm{x} \times \mathrm{x}$ & \\
\hline 3. & $\mathrm{x} \times \mathrm{x} \times \mathrm{x}$ & \\
\hline 4. & $\mathrm{x} \times \mathrm{x} \times \mathrm{x}$ & \\
\hline 5. & $\mathrm{x} \times \mathrm{x}$ & \\
\hline 6. & $\mathrm{x} \times \mathrm{x}$ & \\
\hline 7. & $\mathrm{x}$ & \\
\hline
\end{tabular}


ANEXO 7 
Participante:

Experimentador:

Hierarquia de dicas:

F: Ajuda Física

L: Ajuda Leve

G: Ajuda gestual

I: Independente

Cadeia Comportamental

Data

Tarefa 1:

Tarefa 2:

Tarefa 3:

Tarefa 4:

Tarefa 5:

Tarefa 6:

Tarefa 7:

Tarefa 8:

Tarefa 9:

Cadeia Comportamental

\begin{tabular}{|l|l|l|l|l|l|l|l|l|}
\cline { 2 - 9 } \multicolumn{1}{c|}{ Data } & & & & & & & & \\
\hline Tarefa 1: & & & & & & & & \\
\hline Tarefa 2: & & & & & & & & \\
\hline Tarefa 3: & & & & & & & & \\
\hline Tarefa 4: & & & & & & & & \\
\hline Tarefa 5: & & & & & & & & \\
\hline Tarefa 6: & & & & & & & & \\
\hline Tarefa 7: & & & & & & & & \\
\hline Tarefa 8: & & & & & & & & \\
\hline Tarefa $9:$ &
\end{tabular}


ANEXO 8 
FOLHA E REGISTRO DE DADOS

Participante:

Operante Verbal

Estímulos: A)

B)

C) Branco

\begin{tabular}{|l|l|l|l|l|l|}
\hline & $M$ & $E$ & $C$ & $D$ & $+d_{,}+,-d,-$ \\
\hline 1 & $A$ & $A$ & $B$ & $C$ & \\
\hline 2 & $B$ & $C$ & $A$ & $B$ & \\
\hline 3 & $C$ & $B$ & $C$ & $A$ & \\
\hline 4 & $B$ & $A$ & $B$ & $C$ & \\
\hline 5 & $C$ & $C$ & $A$ & $B$ & \\
\hline 6 & $A$ & $B$ & $C$ & $A$ & \\
\hline 7 & $C$ & $A$ & $B$ & $C$ & \\
\hline 8 & $A$ & $C$ & $A$ & $B$ & \\
\hline
\end{tabular}

Total correto:

Estímulos: A)

B)

C) Branco

\begin{tabular}{|l|l|l|l|l|l|}
\hline & $M$ & $E$ & $C$ & $D$ & $+d,+,-d,-$ \\
\hline 1 & $A$ & $A$ & $B$ & $C$ & \\
\hline 2 & $B$ & $C$ & $A$ & $B$ & \\
\hline 3 & $C$ & $B$ & $C$ & $A$ & \\
\hline 4 & $B$ & $A$ & $B$ & $C$ & \\
\hline 5 & $C$ & $C$ & $A$ & $B$ & \\
\hline 6 & $A$ & $B$ & $C$ & $A$ & \\
\hline 7 & $C$ & $A$ & $B$ & $C$ & \\
\hline 8 & $A$ & $C$ & $A$ & $B$ & \\
\hline
\end{tabular}

Total correto:

+d Correto com Dica

M: Estímulo Modelo
Estímulos: A) Branco

B)

C)

\begin{tabular}{|l|l|l|l|l|l|}
\hline & $M$ & $E$ & $C$ & $D$ & + d, $+,-d,-$ \\
\hline 1 & $B$ & $A$ & $B$ & $C$ & \\
\hline 2 & $C$ & $C$ & $A$ & $B$ & \\
\hline 3 & $A$ & $B$ & $C$ & $A$ & \\
\hline 4 & $C$ & $A$ & $B$ & $C$ & \\
\hline 5 & $A$ & $C$ & $A$ & $B$ & \\
\hline 6 & B & B & C & A & \\
\hline 7 & A & A & B & C & \\
\hline 8 & B & C & A & B & \\
\hline
\end{tabular}

Total correto:

Estímulos: A) Branco

B)

C)

\begin{tabular}{|l|l|l|l|l|l|}
\hline & $M$ & $E$ & $C$ & $D$ & $+d,+,-d,-$ \\
\hline 1 & $B$ & $A$ & $B$ & $C$ & \\
\hline 2 & $C$ & $C$ & $A$ & $B$ & \\
\hline 3 & $A$ & $B$ & $C$ & $A$ & \\
\hline 4 & $C$ & $A$ & $B$ & $C$ & \\
\hline 5 & $A$ & $C$ & $A$ & $B$ & \\
\hline 6 & $B$ & $B$ & $C$ & $A$ & \\
\hline 7 & $A$ & $A$ & $B$ & $C$ & \\
\hline 8 & $B$ & $C$ & $A$ & $B$ & \\
\hline
\end{tabular}

Total correto:
Estímulos: A)

B) Branco

C)

\begin{tabular}{|l|l|l|l|l|l|}
\hline & $M$ & $E$ & $C$ & $D$ & $+d,+,-d,-$ \\
\hline 1 & $C$ & $A$ & $B$ & $C$ & \\
\hline 2 & $A$ & $C$ & $A$ & $B$ & \\
\hline 3 & $B$ & $B$ & $C$ & $A$ & \\
\hline 4 & $A$ & $A$ & $B$ & $C$ & \\
\hline 5 & $B$ & $C$ & $A$ & $B$ & \\
\hline 6 & $C$ & $B$ & $C$ & $A$ & \\
\hline 7 & $B$ & $A$ & $B$ & $C$ & \\
\hline 8 & $C$ & $C$ & $A$ & $B$ & \\
\hline
\end{tabular}

Total correto:

Estímulos: $A$ )

B) Branco

C)

\begin{tabular}{|l|l|l|l|l|l|}
\hline & $M$ & $E$ & $C$ & $D$ & $+d,+,-d,-$ \\
\hline 1 & $C$ & $A$ & $B$ & $C$ & \\
\hline 2 & $A$ & $C$ & $A$ & $B$ & \\
\hline 3 & $B$ & $B$ & $C$ & $A$ & \\
\hline 4 & $A$ & $A$ & $B$ & $C$ & \\
\hline 5 & $B$ & $C$ & $A$ & $B$ & \\
\hline 6 & $C$ & $B$ & $C$ & $A$ & \\
\hline 7 & $B$ & $A$ & $B$ & $C$ & \\
\hline 8 & $C$ & $C$ & $A$ & $B$ & \\
\hline
\end{tabular}

Total correto: -d Incorreto com Dica

E: Esquerda
+ Correto Independente

D: Direita
- Incorreto

C: Centro 